\title{
SRNL Phase 1 Assessment of the WAC/DQO and Unit Operations for the WTP Waste Qualification Program
}

\author{
D.K. Peeler \\ D.J. Adamson \\ C.J. Bannochie \\ A.D. Cozzi \\ R.E. Eibling \\ M.S. Hay \\ E.K. Hansen \\ D.T. Herman \\ C.J. Martino
}

May 2012

\author{
C.A. Nash \\ F.M. Pennebaker \\ M.R. Poirier \\ S.H. Reboul \\ M.E. Stone \\ K.M. Taylor-Pashow \\ T.L. White \\ W.R. Wilmarth
}

Savannah River National Laboratory

Savannah River Nuclear Solutions, LLC Aiken, SC 29808

Prepared for the U.S. Department of Energy under contract number DE-AC09-08SR22470. 
SRNL-STI-2011-00724

Revision 0

\section{DISCLAIMER}

This work was prepared under an agreement with and funded by the U.S. Government. Neither the U.S. Government or its employees, nor any of its contractors, subcontractors or their employees, makes any express or implied:

1. warranty or assumes any legal liability for the accuracy, completeness, or for the use or results of such use of any information, product, or process disclosed; or

2. representation that such use or results of such use would not infringe privately owned rights; or

3. endorsement or recommendation of any specifically identified commercial product, process, or service.

Any views and opinions of authors expressed in this work do not necessarily state or reflect those of the United States Government, or its contractors, or subcontractors.

\section{Printed in the United States of America \\ Prepared for U.S. Department of Energy}


Keywords: Hanford, WTP, $L A W, H L W$, pretreatment, qualification

Retention: Permanent

\section{SRNL Phase 1 Assessment of the WAC/DQO and Unit Operations for the WTP Waste Qualification Program}

\author{
D.K. Peeler \\ D.J. Adamson \\ C.J. Bannochie \\ A.D. Cozzi \\ R.E. Eibling \\ M.S. Hay \\ E.K. Hansen \\ D.T. Herman \\ C.J. Martino
}

May 2012

\author{
C.A. Nash \\ F.M. Pennebaker \\ M.R. Poirier \\ S.H. Reboul \\ M.E. Stone \\ K.M. Taylor-Pashow \\ T.L. White \\ W.R. Wilmarth
}

Savannah River National Laboratory

Savannah River Nuclear Solutions, LLC Aiken, SC 29808

Prepared for the U.S. Department of Energy under contract number DE-AC09-08SR22470. 
SRNL-STI-2011-00724

Revision 0

\section{REVIEWS AND APPROVALS}

LEAD AUTHOR:

D.K. Peeler, Process Technology Programs

Date

APPROVALS:

C.C. Herman, Manager

Date

Process Technology Programs

S.L. Marra, Manager

Date

Environmental \& Chemical Process Technology Research Programs 
SRNL-STI-2011-00724

Revision 0

\section{EXECUTIVE SUMMARY}

The Hanford Tank Waste Treatment and Immobilization Plant (WTP) is currently transitioning its emphasis from a design and construction phase toward start-up and commissioning. With this transition, the WTP Project has initiated more detailed assessments of the requirements related to actual processing of the Hanford Site tank waste. One particular area of interest is the waste qualification program to be implemented to support the WTP. Given the successful implementation of similar waste qualification efforts at the Savannah River Site (SRS), based on critical technical support and guidance from the Savannah River National Laboratory (SRNL), WTP requested the utilization of subject matter experts from SRNL to support a technology exchange to perform a review of the WTP waste qualification program, discuss the general qualification approach at SRS, and to identify critical lessons learned through the support of DWPF's sludge batch qualification efforts.

As part of Phase 1, SRNL subject matter experts in critical technical and/or process areas reviewed specific WTP waste qualification information. The Phase 1 review was a collaborative, interactive, and iterative process between the two organizations. WTP provided specific analytical procedures, descriptions of equipment, and general documentation as baseline review material. SRNL subject matter experts reviewed the information and, as appropriate, requested follow-up information or clarification to specific areas of interest. This process resulted in multiple teleconferences with key technical contacts from both organizations resolving technical issues that lead to the results presented in this report. This report provides the results of SRNL's Phase 1 review of the WAC-DQO waste acceptance criteria and processability parameters, and the specific unit operations which are required to support WTP waste qualification efforts.

The review resulted in SRNL providing concurrence, alternative methods, or gap identification for the proposed WTP analytical methods or approaches. For the unit operations, the SRNL subject matter experts reviewed WTP concepts compared to what is used at SRS and provided thoughts on the outlined tasks with respect to waste qualification. Also documented in this report are recommendations and an outline on what would be required for the next phase to further mature the WTP waste qualification program. 


\section{TABLE OF CONTENTS}

LIST OF TABLES vii

LIST OF FIGURES vii

LIST OF ABBREVIATIONS viii

1.0 Review of Proposed Testing Methodologies for WAC-DQO Gaps. 1

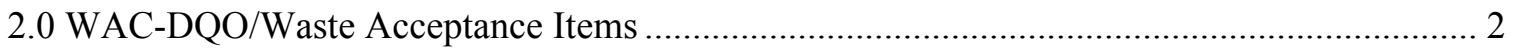

2.1 WAC-DQO Items Classified as "Remains As Gap" ........................................................ 3

2.1.1 Measurement of the Hydrogen Generation Rate during WTP Waste Qualification (Item \#15) 4

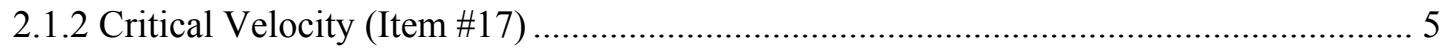

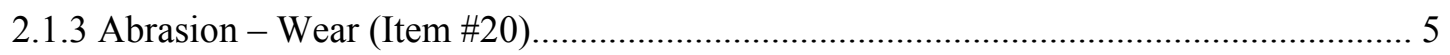

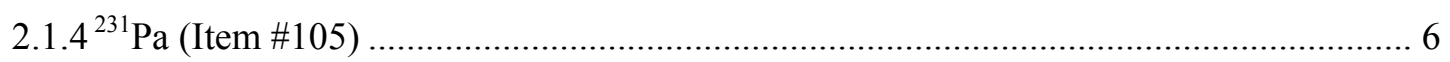

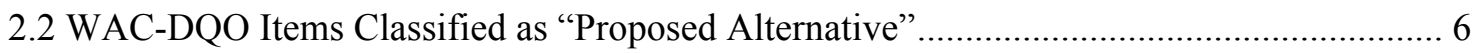

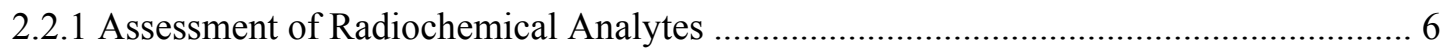

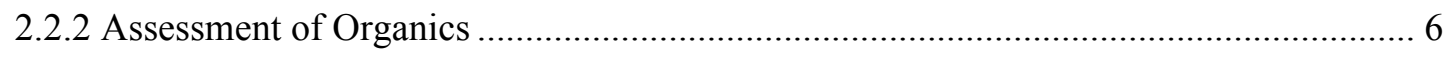

2.3 Assumptions and WAC-DQO Parameters Needing Additional Attention ........................... 7

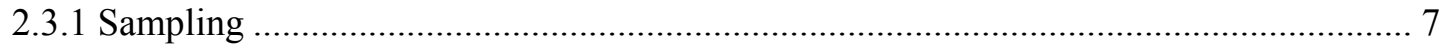

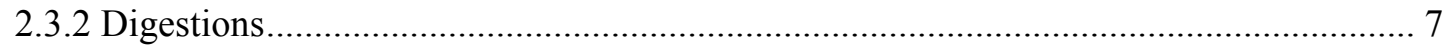

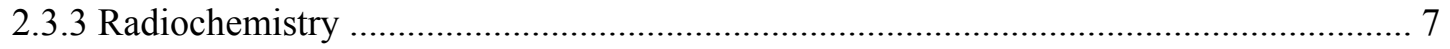

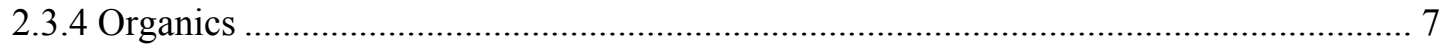

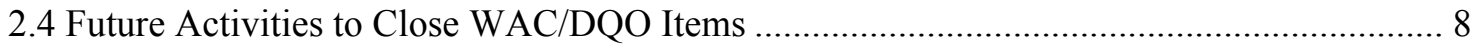

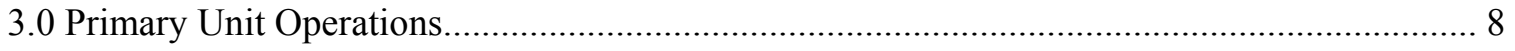

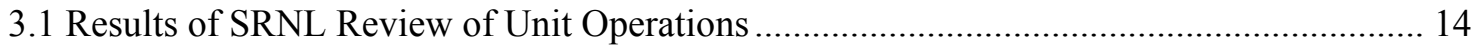

3.1.1 Assessment of WTP Aluminum and Oxidative Leaching........................................... 14

3.1.2 Measurement of Foaming Potential During WTP Waste Qualification........................ 15

3.1.3 Evaluation of FEP Evaporation or TLP Evaporation during WTP Waste Qualification

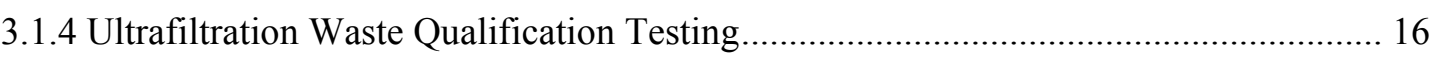

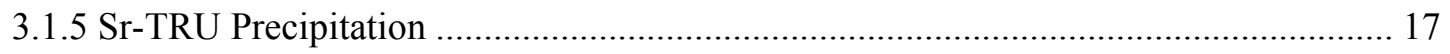

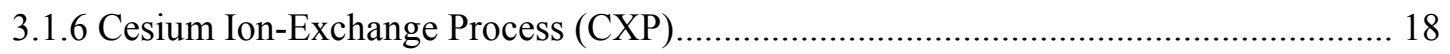

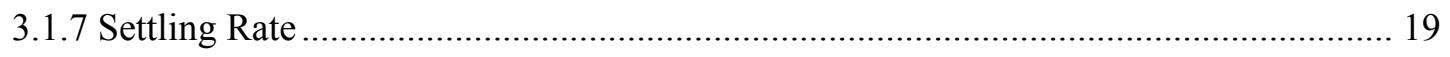

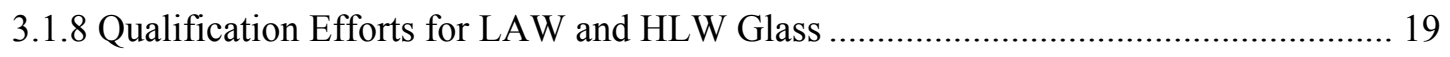

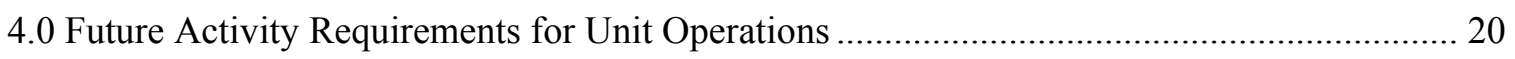

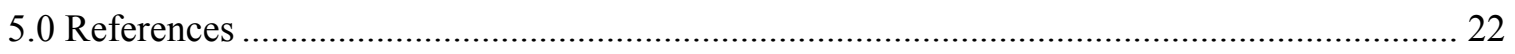




\section{LIST OF TABLES}

Table 2-1. WAC-DQO Parameters Classified as "Remains as Gap" Based on SRNL Phase 1 Review.

Table 2-2. WAC-DQO Parameters Classified as "Proposed Alternative" Based on SRNL Phase 1

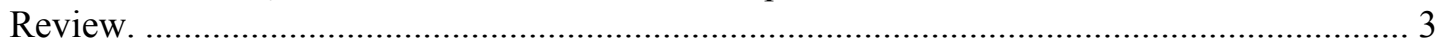

Table A-1. Review of WAC-DQO “Action Limits” Worksheet ................................................ A-2

Table A-2. Review of WAC-DQO "Elemental” Worksheet ..................................................... A-7

Table A-3. Review of WAC-DQO "Rad Chem” Worksheet ................................................ A-21

Table A-4. Review of WAC-DQO “Organics” Worksheet..................................................... A-32

\section{LIST OF FIGURES}

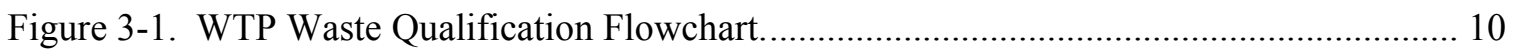




\section{LIST OF ABBREVIATIONS}

\begin{tabular}{|c|c|}
\hline AMP & Ammonium Molybdophosphate \\
\hline CUF & Crossflow Ultrafiltration \\
\hline CXP & Cesium Ion-Exchange Process \\
\hline DQO & Data Quality Objectives \\
\hline DWPF & Defense Waste Processing Facility \\
\hline FEP & Waste Feed Evaporation Process System \\
\hline HAW & High Activity Waste \\
\hline HGR & Hydrogen Generation rate \\
\hline HLW & High Level Waste \\
\hline $\mathrm{ICD}$ & Interface Control Document \\
\hline ICP-AES & Inductively Coupled Plasma - Atomic Emission Spectroscopy \\
\hline ICP-MS & Inductively Coupled Plasma - Mass Spectrometry \\
\hline LAW & Low Activity Waste \\
\hline LEPS & Low Energy Photon Spectroscopy \\
\hline LSIT & Large Scale Integrated Test \\
\hline NRC & Nuclear Regulatory Commission \\
\hline PNNL & Pacific Northwest National Laboratory \\
\hline PT & Pre-Treatment \\
\hline SME & Slurry Mix Evaporator \\
\hline SRNL & Savannah River National Laboratory \\
\hline SRS & Savannah River Site \\
\hline TRU & Transuranic \\
\hline TAT & Turnaround time \\
\hline TEVA & Tetravalent Actinide \\
\hline TLP & Treated LAW Evaporation Process System \\
\hline TOC & Tank Operations Contractor \\
\hline TRU & Transuranic \\
\hline UF & Ultrafiltration \\
\hline UFP & Ultrafiltration process system \\
\hline VD & Vacuum Distillation \\
\hline VSL & Vitreous State Laboratory \\
\hline WAC & Waste Acceptance Criteria \\
\hline WTP & Hanford Tank Waste Treatment and Immobilization Plant \\
\hline
\end{tabular}




\subsection{Review of Proposed Testing Methodologies for WAC-DQO Gaps}

The Hanford Tank Waste Treatment and Immobilization Plant (WTP) is currently transitioning its emphasis from a design and construction phase toward start-up and commissioning. With this transition, the WTP Project has initiated more detailed assessments of the requirements related to actual processing of the Hanford Site tank waste. One particular area of interest is the waste qualification program to be implemented to support the WTP. The waste qualification program involves analyzing staged waste for compliance with waste acceptance and processability requirements within the WTP complex. In general, the waste qualification program involves sampling (performed by the Tank Operations Contractor (TOC) $)^{\mathrm{i}}$, testing and analysis to (a) demonstrate compliance with waste acceptance criteria, (b) evaluate waste processability, and (c) demonstrate laboratory-scale unit operations to support the Pretreatment Facility (PT), the Low Activity Waste (LAW) Vitrification Facility, and the High Level Waste (HLW) Vitrification Facility.

Given the successful implementation of similar waste qualification efforts at the Savannah River Site (SRS), based on critical technical support and guidance from the Savannah River National Laboratory (SRNL), WTP requested the utilization of subject matter experts from SRNL to support a technology exchange to perform a review of the WTP waste qualification program to discuss the general qualification approach at SRS, and to identify critical lessons learned through the support of DWPF's sludge batch qualification efforts. ${ }^{1}$ The primary purpose of the technology exchange (the initial step in the Phase 1 scope) was to review the elements of the existing waste qualification plan and address other testing criteria and strategies identified during development of the data quality objectives for waste acceptance. This Phase 1 activity will support the development of a technically defensible and cost effective approach for waste qualification that can be successfully implemented in the WTP to support operations.

Following the waste qualification technical exchange meeting, WTP provided SRNL with a list of 260 Waste Acceptance Criteria (WAC)-Data Quality Objectives (DQO) items or analytes for which pre-defined methods or approaches had been identified to obtain the required data or information to support the WTP waste qualification efforts. ${ }^{2}$ The WAC-DQO parameters ${ }^{2}$ were supplied by WTP in a spreadsheet in which each WAC-DQO item was identified via a specific tracking number, preliminary sample size information needed to support each analysis or test methodology was provided (for both LAW and HLW), and the WTP proposed analytical method or methodology was also noted. ${ }^{\text {ii }}$ In addition to those items specifically called out in the WACDQO spreadsheet, SRNL also performed a cursory review of the WTP primary unit operations needed to support waste qualification efforts.

As part of Phase 1, SRNL subject matter experts in critical technical and/or process areas reviewed specific WTP waste qualification information. The Phase 1 review was a collaborative, interactive, and iterative process between the two organizations. WTP provided specific analytical procedures, descriptions of equipment, and general documentation as baseline review material. SRNL subject matter experts reviewed the information and, as appropriate, requested follow-up information or clarification to specific areas of interest. This process resulted in multiple teleconferences with key technical contacts from both organizations resolving technical

\footnotetext{
${ }^{\mathrm{i}}$ The qualification strategy is based on a key fundamental assumption that WTP will receive a representative sample from a specific campaign before the TOC is to transfer waste to WTP.

ii The initial version of the WAC-DQO spreadsheet was received on August 18, 2011 via electronic communication from J. Markillie to D. Peeler (CCN 246071) and is based on Reference 2, Tables 4-1 and 4-2.
} 
issues that lead to the results presented in this report. This report provides the results of SRNL's Phase 1 review of the WAC-DQO/feed acceptance criteria and the specific unit operations which are required to support WTP waste qualification efforts.

\subsection{WAC-DQO/Waste Acceptance Items}

The primary objective of this review was to provide feedback on the validity of each WTP proposed analytical methodology in meeting waste characterization objectives. The SRNL review documented (1) concurrence (2) a proposed alternative method (3) or identification of a gap. More specifically, if upon review of each WTP proposed analytical methodology SRNL agreed that use of the methodology would meet the WAC-DQO objectives, "concur" was listed with the proposed method or approach. If SRNL did not agree that the WTP proposed analytical methodology would provide the needed data or was unaware of a more suitable method or an alternative method was being used by SRNL to obtain that specific data, then a classification of "proposed alternative" was used. Lastly, if there was no WTP proposed analytical methodology and SRNL did not have an existing method to propose or if SRNL did not agree with the WTP proposed methodology but SRNL did not have an alternative, then that particular parameter was classified as a "remains as gap". Appendix A provides the results of SRNL's review of the waste acceptance and processability parameters and the corresponding WTP proposed analytical methodologies.

In addition to the proposed analytical methodology for each parameter, WTP also provided suggested procedures, references, and sample preparation methods. Where appropriate, SRNL provided comments or observations on these suggested procedures or references; however, decisions regarding concurrence, proposed alternatives, or gaps were strictly based on whether the WTP proposed analytical methodology would provide the required data or information required for waste characterization objectives.

In general, most of the WTP proposed analytical methodologies identified on the WAC-DQO spreadsheet were ultimately classified as "concur", meaning that SRNL agreed with the proposed methodology or approach by WTP. However, there were sixteen parameters (out of 260) that were classified with "remains as a gap" (four) or "proposed alternative" (twelve). Table 2-1 summarizes the four WAC-DQO parameters which were classified as "remains as gap"; while Table 2-2 identifies the twelve WAC-DQO parameters that were classified as "proposed alternative". 
SRNL-STI-2011-00724

Revision 0

Table 2-1. WAC-DQO Parameters Classified as "Remains as Gap" Based on SRNL Phase 1 Review.

\begin{tabular}{|c|c|}
\hline Item \# & Parameter \\
\hline 15 & Hydrogen generation rate \\
\hline 17 & Critical Velocity \\
\hline 20 & Abrasivity / Wear \\
\hline 105 & ${ }^{231} \mathrm{~Pa}$ \\
\hline
\end{tabular}

Table 2-2. WAC-DQO Parameters Classified as "Proposed Alternative" Based on SRNL Phase 1 Review.

\begin{tabular}{||c|c|}
\hline Item \# & Parameter \\
\hline 102 & ${ }^{59} \mathrm{Ni}$ \\
\hline $117 \mathrm{a}$ & ${ }^{121 \mathrm{~m}} \mathrm{Sn}$ \\
\hline 135 & Pyridine \\
\hline 160 & 3-Heptanone \\
\hline 176 & Cyclohexanone \\
\hline 178 & Tetrahydrofuran \\
\hline 179 & 5-Methyl-2-hexanone \\
\hline 180 & 2-Heptanone \\
\hline 186 & 4-Heptanone \\
\hline 187 & Propanal (n-Propionaldehyde) \\
\hline 195 & 2-Butenaldehyde (2-Butenal) \\
\hline 233 & 3-Pentanone \\
\hline
\end{tabular}

In the following sections more detailed discussions of the four WAC-DQO parameters that were classified as "remains as gap" (Section 2.1) and of the twelve WAC-DQO parameters that were classified as "proposed alternative" (Section 2.2) are provided. In addition, Section 2.3 provides a discussion on specific WAC-DQO items in which SRNL concurred but additional information is presented to ensure the basis for the concurrence is clearly defined or to clarify specific issues that should be highlighted for further consideration. This latter effort is an attempt to discuss potentially subtle issues that may be lost in a review of the WAC-DQO spreadsheet information as presented in Appendix A. The individual discussions provide a high-level summary of the review to either fill the gap for the needed method or to provide additional information on the proposed alternative to ensure the approach is implementable and that it will provide the required data to support the waste qualification program. Alternatively, some of the discussions focus on why SRNL believes a particular analyte should be eliminated from the suite. It should be noted that the open items of ICD-19 (Reference 3) Appendix D were not addressed in the Phase 1 review. ${ }^{3}$ Section 2.4 lists the information that should be obtained in future activities to close the gaps and complete the development of the waste qualification program.

\subsection{WAC-DQO Items Classified as "Remains As Gap"}

In this section, the four WAC-DQO parameters that were classified as "remains as gap" are discussed. These four parameters are: hydrogen generation rate (Item \#15), critical velocity (Item \#17), abrasivity/wear (Item \#20), and ${ }^{231} \mathrm{~Pa}$ (Item \#105). 
SRNL-STI-2011-00724

Revision 0

\subsubsection{Measurement of the Hydrogen Generation Rate during WTP Waste Qualification (Item \#15)}

Hydrogen generation from radiolysis of water is a concern for any facility operating with aqueous solutions or slurries containing radioactive material. Hydrogen generation rates (HGRs) from such slurries have been extensively studied and correlations developed to calculate the expected generation rate based on the specific activities of the radionuclides present. The WTP feed material also contains organic species that can undergo radiolysis; the HGRs from these species have also undergone extensive evaluations and calculations have been developed to determine the HGRs from the materials. At the SRS, available calculations are used to determine the HGRs for liquid systems. However, at WTP, measurement of the hydrogen generation from radiolysis has been specified for the incoming batch prior to processing.

To address the HGRs requirements, a methodology is being developed by the 222-S Laboratory and Pacific Northwest National Laboratory (PNNL). Once this method is finalized, SRNL can provide a review of the technique or approach. Therefore, this WAC-DQO item was classified as "remains as a gap" by SRNL.

Based on SRNL's experience with hydrogen measurements in laboratory scale systems, hydrogen generation rates should ideally be measured using a continuous flow system to allow direct measurement of the steady state hydrogen generation at a given condition. The system should be temperature controlled and it should have mixing capability, an offgas system to condense water and return it to the vessel, and an instrument to measure hydrogen in the offgas flow. Advantages of a continuous flow system are:

- Capability to test stirred and unstirred samples

- Vessel is not sealed, potentially eliminating pressure protection concerns

- Steady state rates can be measured directly by online instrumentation

- Head space samples can still be taken for offline analysis

- Less impacts from small leaks or hydrogen permeation through septums

Disadvantages of the continuous flow system include the complexity of the system and a requirement for the lower detection limits due to the continuous purge diluting the hydrogen.

An assessment of potential detection limits for a HGR system capable of meeting Hanford's detection limits was performed by SRNL assuming $100 \mathrm{~mL}$ of sample with continuous air purge of $5 \mathrm{~mL} / \mathrm{min}$. For this system, hydrogen generation at the action limits would result in hydrogen concentrations of $15.6 \mathrm{ppm}$ for HLW and $2.8 \mathrm{ppm}$ for LAW. ${ }^{\text {iii }}$ Instruments capable of measuring hydrogen concentrations at these concentrations are available, but the LAW value is approaching the limits for online gas analysis. Increasing the size of the sample or decreasing the purge rates could be pursued to increase the hydrogen concentrations expected at the WTP action limits.

A static system could also be used to measure HGRs. A known volume of material could be placed in a sealed container with magnetic stirring. Headspace samples would be taken at set intervals and the HGRs calculated. ${ }^{\text {iv }}$ The advantage of this system is the simplicity. Required detection limits should also be higher as the test can be performed for longer durations to allow the hydrogen concentration to increase as needed to allow measurement. Disadvantages include

\footnotetext{
iii The calculation shown is specific to hydrogen generation, but could be applied to other gases.

${ }^{\text {iv }}$ Note that sampling times would be dependent on the ratio of head space volume to sample size. For a $100 \mathrm{~mL}$ sample and a $100 \mathrm{~mL}$ head space volume, a one hour hold would result in a nominal $50 \mathrm{ppm}$ and $10 \mathrm{ppm}$ concentration if HGR was at the action limits for HLW and LAW.
} 
that steady state conditions are not directly measured, but calculated from the difference between head space samples; heating a sealed vessel is required to perform the test at specified temperatures; and the measurement can be influenced by any leaks in the system or by hydrogen permeation. This method is also less suited to measurement of HGRs under static conditions as steady state is more difficult to determine.

Once the HGRs from a feed batch is measured, calculation of the HGRs during WTP operations is straight forward. However, if measurement of HGRs during WTP unit operations is specified, it could be performed in the same manner as for the feed tank samples using samples taken during the waste qualification program. Depending on the number of measurement points, a substantial increase in the sample requirements could be incurred. Online measurement of HGRs is feasible provided the apparatus is carefully designed to allow the measurement to be performed. The HGRs limit for each unit operation needs to be known to determine if online or analytical instruments are available that can measure the concentrations expected at the action limits, especially if purge rate requirements will limit the ability to prevent large dilutions of the offgas.

Over the long-term and after actual waste qualification data is available from several batches, SRNL recommends that the test results be compared to the calculated rates to determine if existing radiolysis correlations are sufficient to determine the HGRs for future feed streams. Should the calculated rates indicate that the HGRs are predictable, then SRNL further recommends that WTP build the technical basis for phased elimination of the HGRs measurement.

\subsubsection{Critical Velocity (Item \#17)}

LAW feed critical velocity is not measured directly (Reference 3, Table 6). ${ }^{3}$ HLW feed critical velocity is to be measured by the TOC (Reference 3, Table 7). ${ }^{3}$ The TOC method being developed is an in-situ method that will measure the minimum velocity in which a bed of particles start to form for HLW feeds coming to WTP. Once the method developed by the TOC is finalized, SRNL can provide a review of the proposed technique. Therefore, this WAC-DQO item was classified as "remains as a gap" by SRNL.

SRNL believes that literature correlations may provide a means to calculate the critical velocity as a supplement to the tank farm's critical velocity flow loop measurement. An approach that commercial companies would take for pipeline transfer is to calculate the critical velocity using several different correlations, look for consistency between the results, and select the maximum or bounding critical velocity calculated. If this approach proves viable for WTP (and is needed as a supplement or replacement to the TOC approach), implementation in WTP would require the measurement of the relevant properties for each batch to calculate the critical velocity. The relevant properties would include the nominal solids density, liquid density, viscosity, solids concentration, and particle size distribution.

In applying the critical velocity correlations, the distributions of the particle size and solids density have to be given consideration. Should this option become necessary or prove feasible for implementation, the applicable critical velocity correlations need to be compiled with guidelines provided on their use, and sample measurement techniques need to be proposed for the relevant properties.

\subsubsection{Abrasion - Wear (Item \#20)}

As materials are stored and/or transferred through WTP, abrasion or wear on various materials of construction is of interest. No off the shelf test method has been employed for this measurement in radioactive environments. SRNL will review the Dominion Engineering documentation, 
"Bechtel NQA-1 Erosion Testing Final Report" to determine how and if the measurements performed by Dominion Engineering can be incorporated with actual waste. This review will occur at a later date.

If unsuccessful, SRNL can work with WTP to develop methods that can be employed in shielded cells operations. The targeted objective would be to cover the two primary mechanisms of erosion in the WTP, pipe (sliding bed) and direct jet impact. The Miller method (or modified) or modular European design should be considered for the pipe erosion tests (other tests may be considered). The method for the jet impact test is to be determined and its feasibility assessed.

\subsection{4 ${ }^{231} \mathrm{~Pa}$ (Item \#105)}

WTP is currently reviewing the waste compliance documentation to evaluate if ${ }^{231} \mathrm{~Pa}$ will ultimately be an element that must be reported based on anticipated or measured concentrations. Once that review is complete, ${ }^{231} \mathrm{~Pa}$ may be removed from the list of WAC-DQO parameters to be analyzed. If not, SRNL will work with WTP to ensure the proposed analytical methodologies will meet the data quality objectives. Therefore, this WAC-DQO item was classified as "remains as a gap" by SRNL.

\subsection{WAC-DQO Items Classified as "Proposed Alternative"}

The associated proposed analytical methods for all compositional analysis (elemental, radiochemical, and organic analysis) were reviewed to confirm the methodologies to be used during waste qualification would generate the required data. In general, the majority of methods were confirmed to be appropriate to meet WTP specifications (as shown in Appendix A). The twelve WAC-DQO parameters classified as "proposed alternative" came from either the review of the radiochemical (Items \#85 through \#130) or organic species (Items \#131 through \#258) lists.

\subsubsection{Assessment of Radiochemical Analytes}

Two of the "proposed alternative" parameters are from the radiochemical list (see Appendix A-3). An alternate method for measurement of Ni-59 (Item \#102) has been provided to WTP. This method is documented in Coleman et $\mathrm{al}^{4}$. For Sn-121m (Item \#117a), SRNL typically performs low energy photon spectroscopy (LEPS) on digest solutions treated with ammonium molybdophosphate (AMP) to remove cesium prior to measurements.

\subsubsection{Assessment of Organics}

The methods presented for WTP analyses of organic species, broken down into several broad categories, were evaluated against published EPA recommended methods (where available) and/or SRNL experience. One key guide was SW-846, Chapter 2, Rev. 4 (February 2007) Table 2-1, "Determination Methods for Organic Analytes", which lists the applicable EPA methods for a variety of organic species. In some instances differences between the EPA's recommended method and that proposed by WTP were encountered, many times this involved the WTP proposed use of Method 8260 and Method 8270, when only 8260 was approved by the EPA, or the proposed use of Method 8082 (PCB analyses) when Method 8270 was also recommended (see Sections 4 and 8 in Reference 5). ${ }^{5}$ Recommendations have been made for WTP to consider the alternative methods for several specific analytes.

Pyridine (Item \#135) is not recommended for EPA Method 8270, though it is listed with a caution about concerning the GC injection port temperature, therefore EPA Methods 8015, 8260, or 8261 
are recommended for this analyte. The EPA-recommended method for tetrahydrofuran (Item \#178) is EPA Method 8261, vacuum distillation (VD) in combination with GC/MS; WTP has demonstrated experience with this analyte by 8260 (Reference 5). The EPA Method 8315, HPLC, is recommended for carbonyl containing species such as 3-heptanone (Item \#160), cyclohexanone (Item \#176), 5-methyl-2-hexanone (Item \#179), 2-heptanone (Item \#180), 4-heptanone (Item \#186), propanal (n-propionaldehyde) (Item \#187), butenaldehyde (Item \#195), and 3-pentanone (Item \#233).

\subsection{Assumptions and WAC-DQO Parameters Needing Additional Attention}

\subsubsection{Sampling}

Although not specifically identified in the WAC-DQO spreadsheet, a potential issue with Hanford related samples is the rate of settling and its impact on sampling. If fast settling solids are present, issues could arise with the TOC's attempt to obtain a representative sample for waste qualification and/or during sampling for the various unit operations. As part of future assessments, SRNL will work with WTP to ensure that method(s) for obtaining and handling subsamples are not impacted by the settling rate and that they lead to representative samples for these types of systems. SRNL recommends that WTP and the TOC ensure that the definition of "representative sample" is consistent between the two entities to ensure continuity and to mitigate any downstream issues that may resolve due to differences in that definition.

\subsubsection{Digestions}

WTP has identified various sample preparation methods for elemental and radiochemical characterization. It should be noted that this suite of techniques is necessary to complete sample preparation for the variety of chemical species and forms expected in the WTP process. In many cases, a fusion or aggressive digestion will be necessary to fully solubilize the element of interest. Additionally, dissolution of HLW may be challenging due to the dose rates involved when working with sludge samples. It is expected that many of these types of sample preparations will be performed in shielded cells.

\subsubsection{Radiochemistry}

There are several radiochemistry methods which are appropriate to measure the radionuclides; however, the low levels present in many of the samples will likely necessitate alternate methods (to lower the analytical minimum detection limits). These radionuclides have previously been identified by WTP as needing method development. SRNL has performed low level measurement of some of these nuclides, but additional confirmation of applicability to WTP is recommended. The primary nuclides falling into this category include: Zr-93, Ra-226, Th-229, and Pa-231. SRNL is prepared to provide method development support for analyzing low concentrations of these nuclides, if needed.

\subsubsection{Organics}

Some concerns remain over sampling issues. Some of the proposed analytes are insoluble solids and would be expected to be highly partitioned to the insoluble solids phase of a sample. It will be important for good mixing to occur during slurry sampling to ensure an accurate ratio of supernate to insoluble solids. Many of the insoluble species (e.g., highly substituted naphthalene) are also called out in the LAW supernate samples where they would not be expected to occur to any great extent. In addition, the challenge of analyzing this extensive list of trace organic species in the HLW and LAW streams should warrant further review of the waste qualification process development list for analytes that may be justifiably removed from the WAC. 


\subsection{Future Activities to Close WAC/DQO Items}

To allow for finalization of the feed acceptance WAC/DQO methods, future activities will require closure/definition of the following items:

- Develop the analytical flow diagram,

- Specify the sample volume required, and

- Finalize the integrated flow sheet and specify material flow.

These items are in addition to the items identified above (refer to Table 2-1 and Table 2-2 and Sections 2.1 and 2.2 for more detail) which must be completed to close remaining gaps or to further develop proposed alternatives (as warranted). For the analytical flow diagram, SRNL will help identify the sequencing and subsampling for the required analytical methods to ensure that the required data are collected. SRNL will also help optimize the sequencing to minimize the quantity of sample required and to reduce sample turnaround time. This in turn will lead to the specification of the sample volume required to complete the WAC/DQO analyses/measurements. The combined information will be fed into the integrated flowsheet to ensure that sufficient test material is available to test all of the unit operations and collect the required data.

\subsection{Primary Unit Operations}

Figure 3-1, initially developed as part of the workshop, outlines the anticipated sampling and testing program to support waste qualification at WTP. The figure provides a snapshot of the magnitude of the present WTP waste qualification program and will likely serve as the basis for more detailed sampling plans and material flowsheet assessments for the project. Figure 3-1 shows the primary unit operations (i.e., Al and oxidative leaching, foaming potential, waste feed evaporation process (FEP), treated LAW evaporation process (TLP), ultrafiltration process system (UFP), settling rate (LAW), Cs ion-exchange, and HLW/LAW glass) as well as the WACDQO parameters (e.g., physical characterization, chemical characterization, and radiological characterization) (as discussed in Section 2.0).

SRNL subject matter experts also performed a cursory review of the WTP primary unit operations that were classified (as a result of the WTP waste qualification workshop) as requiring additional development in order to support the qualification effort. These items were reviewed to ensure that testing protocols are fundamentally sound and/or to provide alternative approaches that may provide technology off-ramps for WTP consideration as the waste qualification program matures. In addition, SRNL's Phase 1 review sometimes identified methods or approaches to enhance testing capabilities/equipment with respect to robustness and reliability and/or identified future scope that could be performed to enhance the waste qualification efforts.

In Section 3.1, the following primary unit operations are discussed: $\mathrm{Al}$ and oxidative leaching, foaming potential, waste feed evaporation, treated LAW evaporation, cross-flow ultra-filtration, Sr-TRU precipitation, settling rate (LAW), Cs ion-exchange, and HLW/LAW glass. Section 3.1 provides the results of SRNL's review of the WTP unit operations and, as warranted, provides insight into how these unit operations are addressed to support qualification efforts at SRNL. Section 4.0 provides a high level outline of the steps required in future activities to close out any remaining gaps for the unit operations and to ensure the necessary equipment is available to complete waste qualification testing.

Prior to an individual review of each unit operation, although obvious, it must be mentioned that the individual units are ultimately integrated in the facility. Thus, integration of the overall 
flowsheet is mandatory and is a key attribute of the development and successful implementation of the waste qualification program. Integration ensures that material flow and material balances proceed without deficiencies and the overall qualification program provides the required data to support WTP operations for each campaign. SRNL will work with WTP to ensure integration of the WTP waste qualification program as the testing program for each unit operation is developed, evaluated, and/or tested as part of future activities. 


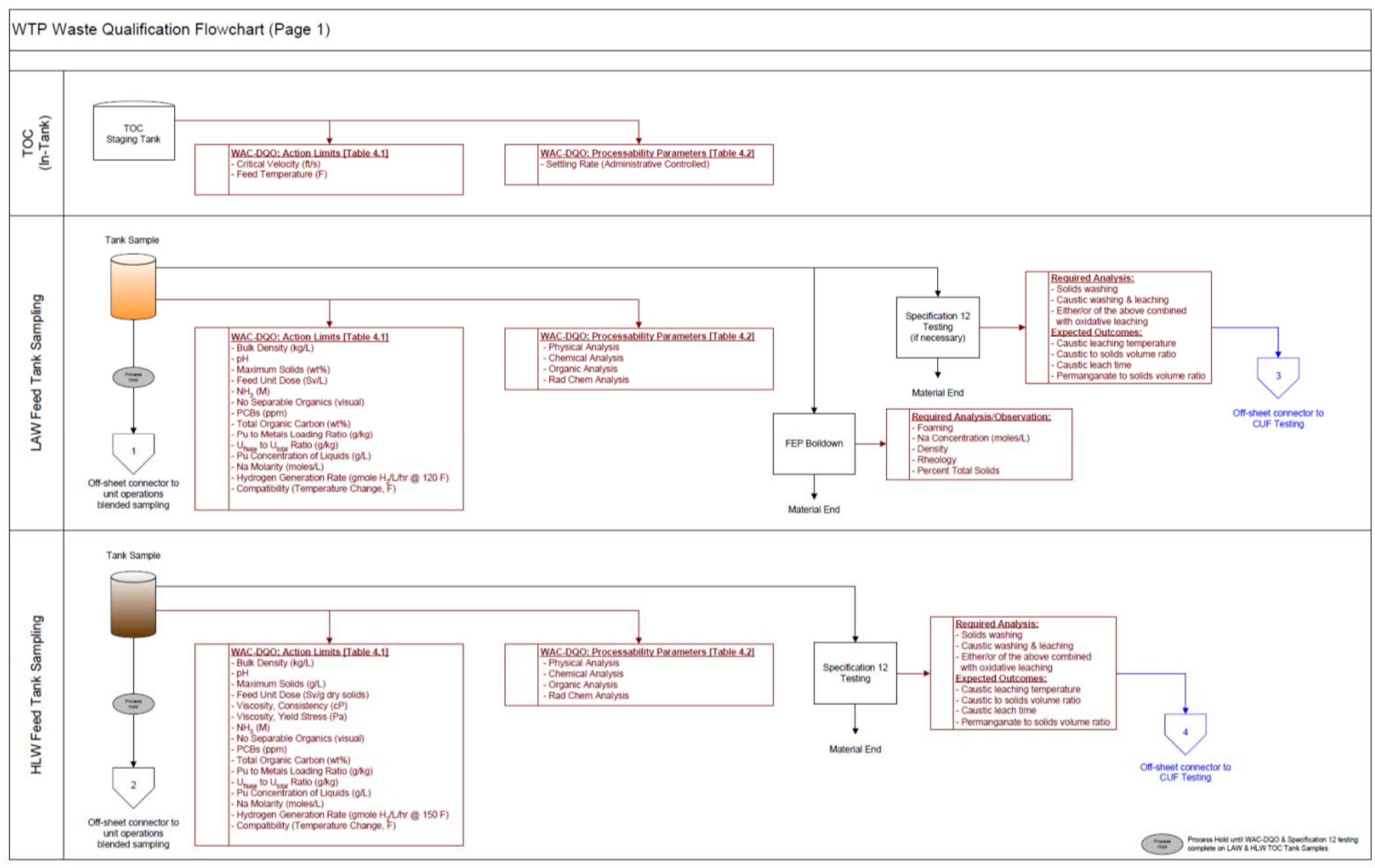

Figure 3-1. WTP Waste Qualification Flowchart. 


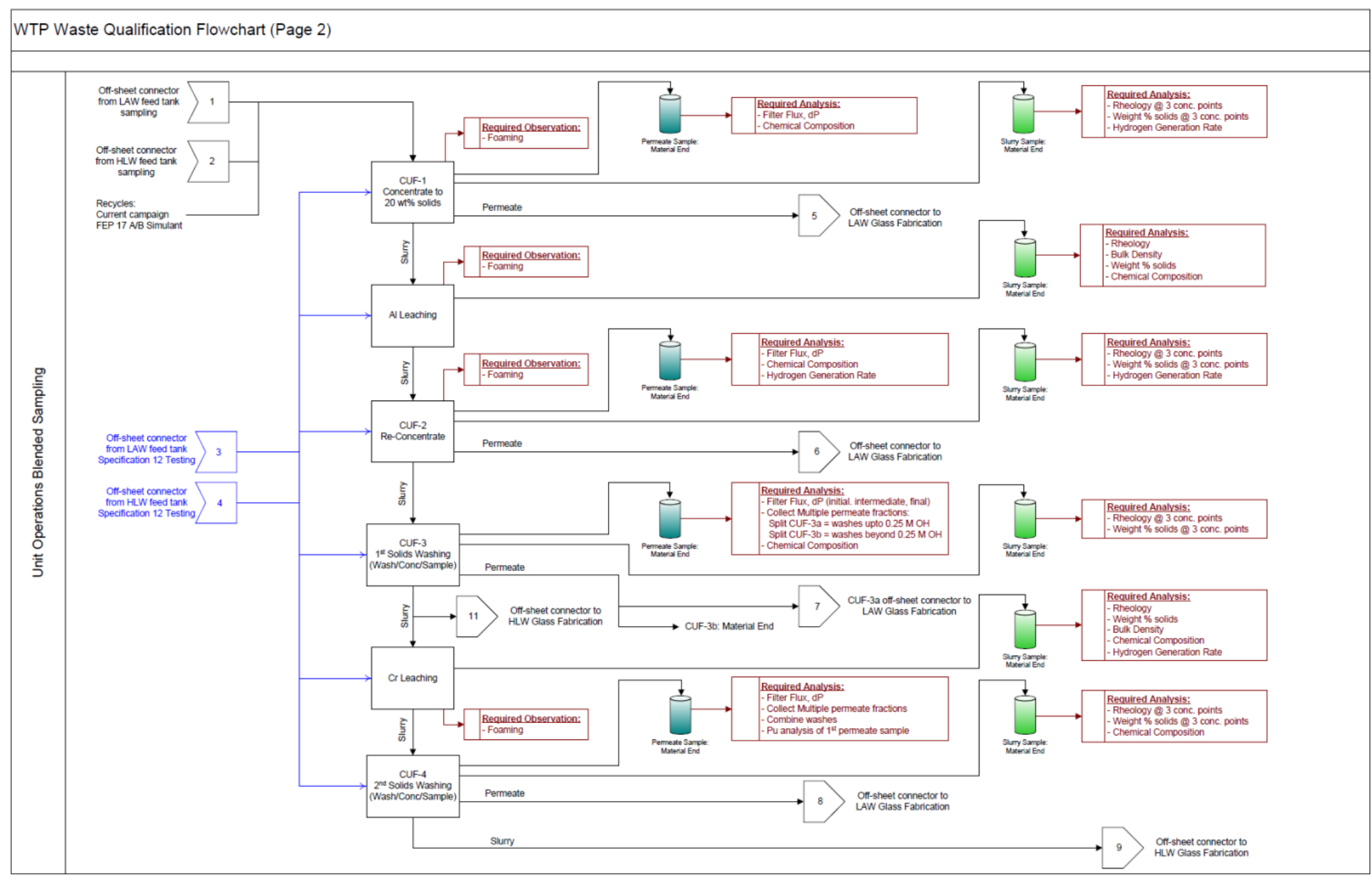

Figure 3-1. WTP Waste Qualification Flowchart. (continued) 


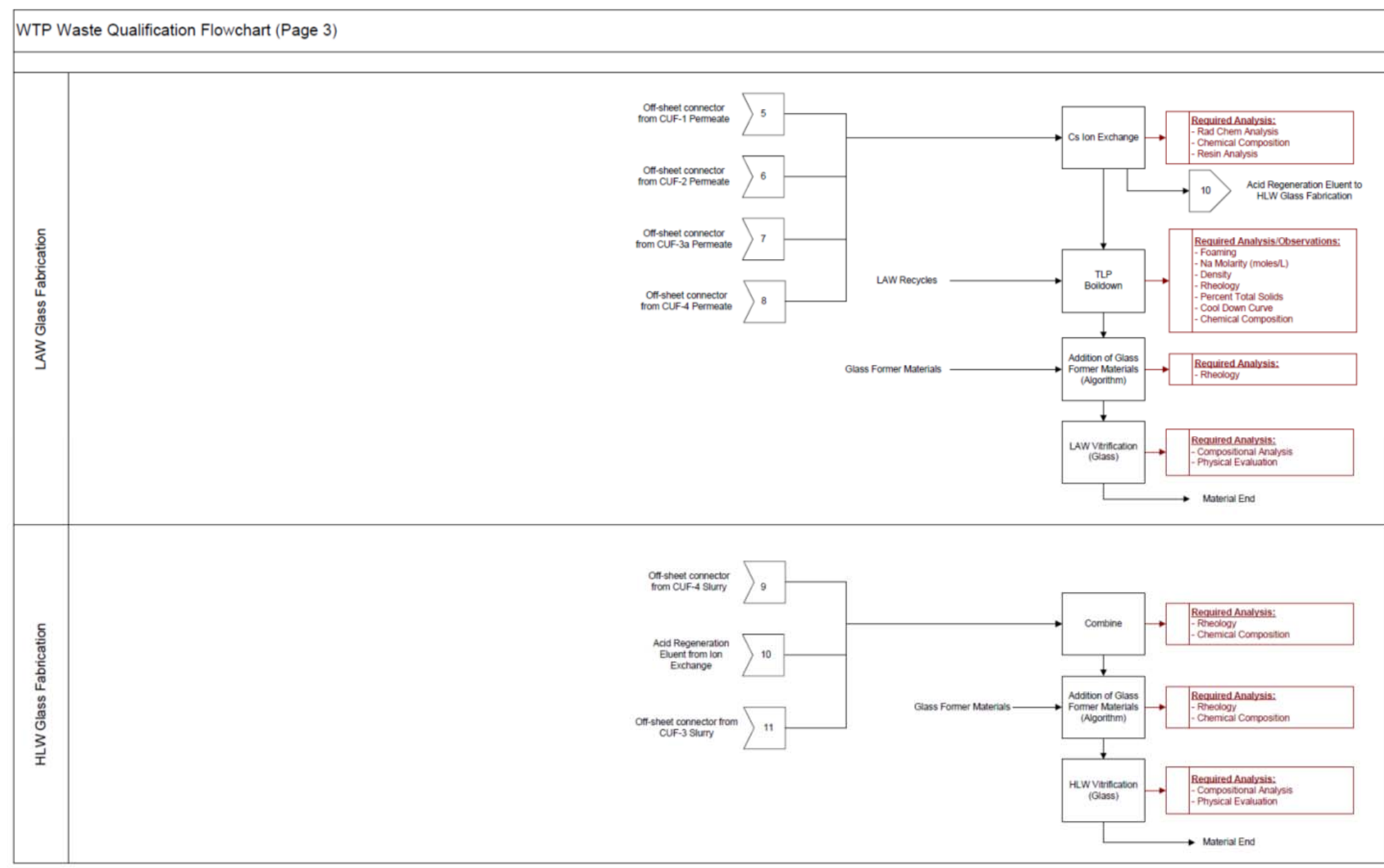

Figure 3-1. WTP Waste Qualification Flowchart. (continued) 


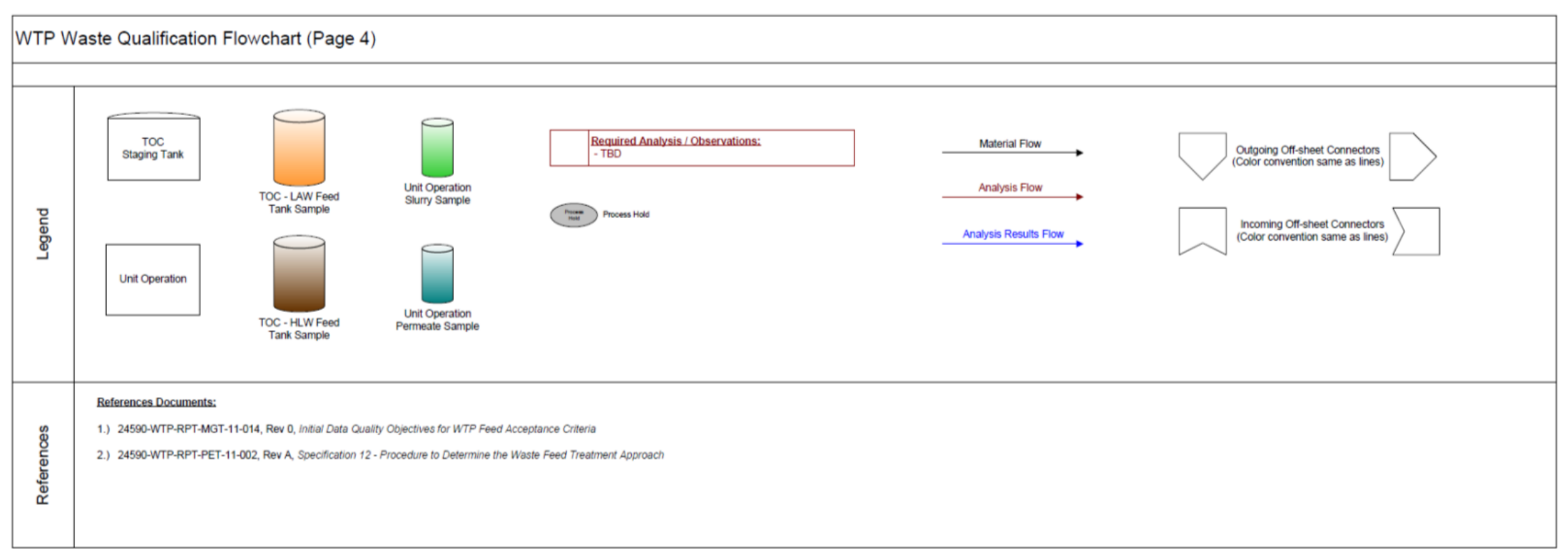

Figure 3-1. WTP Waste Qualification Flowchart. (continued) 
SRNL-STI-2011-00724

Revision 0

\subsection{Results of SRNL Review of Unit Operations}

\subsubsection{Assessment of WTP Aluminum and Oxidative Leaching}

The general approach to Aluminum and Oxidative Leaching described in the preliminary Specification 12 procedure ${ }^{6}$ using actual waste appears sound, but the prescribed nature of the specification may lack flexibility and require more actual waste testing than may be necessary. Sufficient timing will be key to meeting the timeline for completing the waste qualification testing. The sooner the sludge composition is known, the sooner upfront modeling could be used to narrow down the washing/leaching needs of the sludge batch to yield an adequate glass waste form.

Ultimately, an integrated approach is required starting with a sludge batch composition (liquid and solids) that feeds into modeling sludge processing. The sludge batch composition, and possible sludge compositions from washing/leaching, feed into modeling of the glass waste form for some processes and parameters and to verify glass formulation properties predicted from the composition.

Simulants can be used to evaluate sludge composition; however, simulants to mimic leachability of the sludge are more problematic. In addition to the chemical composition of the sludge, the chemical form of the components to be leached must be accurately known to produce an adequate sludge simulant to test for leaching behavior. Thus, a potential way to optimize the waste qualification program would be to perform upfront (pre start-up) modeling and simulant testing to reduce the qualification real wastes tests to a small number of confirmation runs.

Some additional points relating to the Aluminum and Oxidative Leaching testing protocol based on experiences at the SRS:

- At SRS, the water volume and number of washes are determined for each individual sludge batch based on the composition of the sludge and associated supernatant liquid transferred with the sludge into the processing tanks. This is based on lessons learned at SRS since a nominal endpoint was used in early sludge batches. Typically, six to ten wash cycles may be required to reduce sodium and associated anion concentrations in the sludge batch to meet DWPF processing and glass waste form requirements.

- The mineral phases of aluminum and relative amounts of each phase present in the sludge sample should be determined prior to or as part of waste qualification testing. The concentration of the difficult to dissolve boehmite phase present in the waste will greatly impact test conditions required to dissolve the aluminum. In the dissolution of two recent high aluminum sludge batches completed at SRS, $\sim 90 \%$ of the aluminum was determined to be in the harder to dissolve boehmite form. When requested to support Tank Farm Al dissolution, SRNL uses a small sample volume test method combined with x-ray diffraction analysis to determine the aluminum phase composition. This small scale test is not part of the official DWPF sludge batch qualification program.

- The maximum contact times (24 hr) for the aluminum dissolution may be insufficient to dissolve the boehmite phase in sludge wastes. At SRS, boehmite dissolution at $60-$ $70{ }^{\circ} \mathrm{C}$ requires several weeks to dissolve, while the easier to dissolve gibbsite phase can be dissolved on the order of hours. The prescribed test conditions for aluminum leaching in Specification 12 may need to be more flexible and be guided by the sludge composition and modeling results. 
- Flowsheet and thermodynamic modeling can be used to estimate the test conditions needed for sludge batch preparation. This can greatly reduce the number of tests required for aluminum/oxidative leaching and can also provide conditions to keep the aluminum in solution after leaching.

- Analytical sample turnaround from the testing is typically a rate determining step in the testing process at SRNL. Sufficient analytical resources need to be provided for the Specification 12 testing to complete the protocol in the prescribed time period. It should also be noted that WTP may be qualifying 3 to 4 HLW batches a year (more if the TOC cannot meet the targeted solids concentrations) which may place more schedule and resource pressure on the waste qualification process.

\subsubsection{Measurement of Foaming Potential During WTP Waste Qualification}

Foaming during processing was noted in several laboratory and pilot scale unit operations during initial testing of the WTP flowsheet. ${ }^{7-10}$ Foaming during evaporator testing led to the recommendation for use of an antifoam agent: Dow Q2-3183a ${ }^{\mathbb{B}}$. Foaming was also noted during ultrafiltration testing.

Performance of the actual boil-down test to evaluate foaming in the waste feed evaporation process system (FEP) and the treated LAW evaporation process system (TLP) is straight-forward and should utilize expertise gained from previous laboratory scale testing of the WTP process streams and DWPF sludge batch qualification. Antifoam agents would be added at the expected concentration for WTP operation and a limit (perhaps 25\%) would be placed on the amount of foam observed. The evaporator flux would be required to be at least $10-20 \%$ of the expected evaporator flux. The apparatus and test parameters will need to be flexible enough to allow the evaporation process to be sized to produce enough material for subsequent unit operations in the waste qualification test program. Condensate should be collected to allow calculation of the solids content at any point during the test as a maximum in foaming is typically seen as material is concentrated.

Solids content and particle size are primary contributors to the foaming of HLW streams, therefore the evaluation of foaming in the FEP and TLP evaporators is complicated by the amount and variety of recycle streams expected to be fed to the evaporators. As part of the waste qualification program, a test matrix may be required to evaluate the impact of various combinations of recycle with the waste feeds. The front end evaporator processes a more diverse set of waste and recycle streams and represents a greater challenge in developing this matrix of tests. Simulants of the recycle streams will be required for this testing.

Evaluation of foaming during other unit operations requires the apparatus to be designed to allow observation of the interior of process vessels. It should be noted that while visual observations have been successfully used to measure foaming during past testing, coating of the observation window is difficult to prevent or remove during some tests. Therefore, should it be necessary to determine foam potential in closed systems or in the actual WTP vessels, measurement of foam height may be possible from an instrument such as the Charis Multisense probe and IMA sensing ${ }^{\circledR}$ technology. While a measurement of the quantify of foaming may not be necessary, this technique would warn the operator of a potential processing issue so antifoam could be added when needed.

SRNL has been working toward a standardized method for foaming potential using the Teclis Foamscan ${ }^{\circledR}$ instrument. This instrument uses a sparge column and camera system to measure the 
foaming characteristics of a fluid. The standardized method could simplify the test protocol for foaming, but development work is still needed as the current program has only utilized simulants.

\subsubsection{Evaluation of FEP Evaporation or TLP Evaporation during WTP Waste Qualification}

Performance of a boil-down test to evaluate mixing, foaming and crystallization in the FEP evaporator/TLP evaporator is straight-forward and would utilize expertise gained from previous laboratory scale testing of the WTP process streams and DWPF sludge batch qualification. The primary goal of the tests would be to verify that the waste feed or treated feed can be concentrated to the maximum required concentration without excessive foaming, without excessive crystallization of solids, and without producing a product that is too viscous for WTP operation. Recommendations for processing parameters will be made, but it should be understood that the range of the amount and type of recycle can significantly impact the evaporator operation and that one set of processing parameters may not be sufficient. The primary difference between the FEP evaporator and the TLP evaporator is that the feed to the LAW evaporator has to be the unit operation product from the ultrafilters/ion exchange tests and does not start with the initial waste qualification feed sample. Since appropriate recycle stream samples may not be available, suitable simulants will have to be chosen to represent those streams.

It is recommended that the qualification of evaporation processes utilize process modeling or simulant testing performed on a standard matrix of possible scenarios and the radioactive evaporator testing be used to validate the model/simulant testing. The validation process may initially require a significant number of tests to evaluate the impact of various combinations of expected recycles with the waste feeds. Simulants of the recycle streams will be required for this testing. As experience is gained in qualifying batches, reductions in the test matrix for radioactive testing may be warranted.

Antifoam agents would be added at the expected concentration for WTP operation and a limit (perhaps 25\%) would be placed on the amount of foam observed. The evaporator flux would be required to be at least $10-20 \%$ of the expected evaporator flux. The apparatus and test parameters will need to be flexible enough to allow the evaporation process to be sized to produce enough material for subsequent unit operations in the waste qualification test program. Condensate will be collected to allow calculation of the solids content at any point during the test as a maximum in foaming is typically seen as material is concentrated. Measurement of hydrogen gas generation rate during evaporator testing is possible using online gas chromatography or mass spectroscopy, but the sensitivity of the measurement will be impacted by the amount of inleakage and vacuum control air added.

Samples would be taken during the evaporation process. The solids content (insoluble and soluble solids) would be measured along with supernate concentrations of metals to determine if any solids precipitation was occurring. Rheological property measurements would be measured on the concentrated feed.

As part of future activities, SRNL recommends that a prototypical apparatus for use during the boil down tests be designed, fabricated and tested with WTP simulants.

\subsubsection{Ultrafiltration Waste Qualification Testing}

The crossflow ultrafiltration (CUF) process is the central process in the WTP. Filtration performance is critical for the processing plant to meet production goals. SRNL recommends the evaluation of the body of literature currently produced on filtration of Hanford simulants and 
actual waste samples. The literature review will identify areas where the previous CUF apparatus could be improved. WTP has already identified the following items in Phase 1 discussions; slurries with high yield stress are difficult to cool with the current CUF configurations, pump types need to be evaluated that provide the required attributes and life for CUF operations, and material turnover of the slurry reservoir versus the pump flow rate needs to be considered. The literature review is intended to identify other areas of potential improvement such as fouling prevention and cleaning protocols.

Following the literature review, development of a robust system that is durable enough to be used for a larger number of tests should be evaluated as well as modifications that could improve the scalability of results. The current CUF configurations have been developed for short term testing. An evaluation of previous configurations should be completed in order to incorporate any modifications to increase the lifetime of the apparatus, operability during test campaigns as well as maintenance and component replacement.

The updated CUF test apparatus should be evaluated using simulants prior to the acceptance of the system for waste qualification testing. SRNL recommends the fabrication and testing of a CUF system based on the lessons learned from past testing. The CUF system design will be evaluated for improvements to the robustness of the system as well as scalability.

As part of the future activities scope, the use of a dead-end filtration test as a scoping tool to support CUF testing should be evaluated. Filter cake resistance is a dominant factor in filtration rate. The goal would be to predict relative CUF process performance as compared to other feeds based on a small sample run in a dead-end filter. To qualify and implement this alternative, a test would be developed that could be correlated with the relative throughput of cross flow filtration. Initial tests would be carried out with simulants followed by tests on actual waste samples.

The results from the dead-end filtration testing will be compared to bench scale CUF testing simulants. This will correlate the dead-end tests to cross flow tests for a relative prediction of cross-flow filtration performance of feed slurries based on the small sample dead-end filtration tests. The method will also provide a screening test of potential rheological modifiers or filter aids if a need for these additions is identified during waste qualification testing or plant operating experience.

\subsubsection{Sr-TRU Precipitation}

There are two identified tanks (241-AN-102 and 241-AN-107) that will require processing to remove strontium and actinides to meet the contract requirements and the Nuclear Regulatory Commission (NRC) Class C Waste limits. ${ }^{11}$ The contract limits for $\mathrm{Sr}$ and actinides are $20 \mathrm{Ci} / \mathrm{m}^{3}$ of LAW glass and less than $100 \mathrm{nCi} / \mathrm{g}$ of LAW glass, respectively. The original WTP flowsheet was to be performed in the Pretreatment Facility; however, current plans are to perform this operation in the tank farm prior to transferring feed to WTP. However, WTP by contract must maintain the capability to perform Sr/TRU precipitation and therefore, if required, waste qualification will be performed to establish the campaign specific Sr/TRU precipitation parameters needed to meet the contractual requirements.

SRNL and Battelle personnel demonstrated a process for separating the Sr-90 and TRU components from the Envelope $\mathrm{C}$ wastes which may be applicable to WTP needs. This new process uses addition of a strontium nitrate solution to precipitate strontium carbonate following a caustic adjustment step. The strontium addition imparts an isotopic dilution for the radioactive strontium. This is followed by an addition of a sodium permanganate solution that forms a 
precipitate of manganese oxides or hydroxides that incorporates the transuranic components in the waste. The optimized reagent levels for cold feed minimization are $0.3 \mathrm{M}$ sodium hydroxide, $0.035 \mathrm{M}$ sodium permanganate, $0.01 \mathrm{M}$ strontium nitrate and $50{ }^{\circ} \mathrm{C}$. If elevated temperatures are avoided, then a different set of operating conditions can be found. For example, the conditions for an ambient temperature flowsheet (based strictly on lab-scale testing, not demonstrated at the pilot scale) were defined as $1 \mathrm{M}$ hydroxide, $0.01 \mathrm{M}$ strontium nitrate and $0.075 \mathrm{M}$ sodium permanganate. ${ }^{12}$

Testing was performed on the $50 \mathrm{~mL}$ scale using 241-AN-107 and 241-AN-102 simulants spiked with ${ }^{85} \mathrm{Sr},{ }^{241} \mathrm{Am}$, and ${ }^{239} \mathrm{Pu}$ tracers in round-bottom flasks. The simulant was adjusted to the hydroxide concentration using sodium hydroxide pellets. The solution was stirred with a magnetic stirrer and then heated to the required temperature with heating mantle. An aliquot of the strontium precipitating agent $\left(1 \mathrm{M} \mathrm{Sr}\left(\mathrm{NO}_{3}\right)_{2}\right)$ was added. The precipitate slurry was stirred for 15 minutes at temperature prior to the addition of the second precipitating agent $(1 \mathrm{M}$ $\mathrm{NaMnO}_{4}$ ). After the second addition, the slurry was stirred at the specified temperature in either the water bath or in a temperature-controlled oven for a total of 4 hours. The samples were allowed to cool to ambient temperature for at least 1 hour and filtered through a 0.45 -micron filter. Aliquots of the liquid phase were filtered successively through 0.2 and $0.1 \mu \mathrm{m}$ filters and sent for radiochemical analysis (liquid scintillation analysis for strontium-90, alpha pulse height analysis and Inductively Coupled Plasma - Mass Spectroscopy (ICP-MS)). The solid, Sr-TRU precipitates from the $0.45 \mu \mathrm{m}$ filtration step were submitted for analysis. Once results are received from the qualification experiment, the $\mathrm{Sr}$ and actinide concentrations are compared to the contract limits. If the results indicate that $\mathrm{Sr}$ and the actinides are less than $20 \mathrm{Ci} / \mathrm{m}^{3}$ of LAW glass and less than $100 \mathrm{nCi} / \mathrm{g}$ of LAW glass, respectively, then the qualification experiment shows the process should be capable of processing the feed.

In summary, the strontium and transuranic decontamination process has been well established as only two tanks are expected to require pretreatment. Two optimized flowsheets exist based on two operating temperatures. Once the WTP is operational and begins to process these two tank feeds and the operating temperature is established, the laboratory experiment defined above can be used to determine whether the material can be successfully processed. There does not appear to be a technical gap that would prevent the determination if the feed can be processed. However, SRNL will work with WTP to define the protocols to be implemented into waste qualification testing and/or facility operations.

\subsubsection{Cesium Ion-Exchange Process (CXP)}

The WTP Pre-Treatment process will use resourcinol formaldehyde ion-exchange resin to remove the ${ }^{137} \mathrm{Cs}$ from liquid waste prior to immobilization as LAW glass. The ${ }^{137} \mathrm{Cs}$ on the ion exchange columns will be eluted and combined with the HLW for vitrification. Cesium removal from the liquid to LAW will target less than $0.3 \mathrm{Ci} / \mathrm{m}^{3}$ in glass to facilitate a maintenance requirement for the LAW melter as well as meet a $3 \mathrm{Ci} / \mathrm{m}^{3}$ limit for Operation Specification Section C.8, Spec. 2.2.2.8. ${ }^{\mathrm{v}}$ The efficiency of the ion-exchange columns to remove Cs will be dependent on the composition of the feed and operating conditions of the column. The primary variables affecting column performance include the concentrations of sodium, potassium, cesium, and free hydroxide in the feed, along with temperature and flow rate. Feed to the ion-exchange columns will be the permeate from the ultrafiltration process. Additions may be made to the permeate from the ultrafiltration process to prevent solids reprecipitation and adjust the sodium concentration to between 4 and $6 \mathrm{M}$, if necessary. ${ }^{13}$

${ }^{v}$ WTP Contract, Contract No. DE-AC27-01RV14136, Section C, Statement of work, Conformed through Modification No. 230. 
The current plan for WTP waste qualification testing outlines a single small laboratory column loading and elution cycle, along with spent resin analysis, at conditions specified by WTP. ${ }^{14}$ This testing should provide a confirmation of the plant processing parameters for that campaign. The testing will receive lab scale filter permeate and provide column product and eluates for characterization and further LAW and HLW testing at the lab scale. Waste qualification testing will examine trace elements retained on the resin after elution, including plutonium, cesium, mercury, chromium, and neutron absorbers. Resin cycling in the small column may include regeneration. The spent resin from the lab column would be characterized for resin disposal evaluation. Consideration must also be given to what other pre-treatment processes the waste will be subjected to prior to reaching the ion-exchange columns, and any recycle streams that will be added to the column feed. Therefore, SRNL recommends that the waste qualification protocol take into account the potential upstream effluents and downstream recycle streams until their impact can be demonstrated. As any new data are generated, it should be used to further enhance the existing ion-exchange modeling capabilities for implementation in WTP to help build the technical basis for eliminating or minimizing the waste qualification test.

\subsubsection{Settling Rate}

A LAW transfer criterion associated with settling rate (no criterion exists for HLW) is defined in the ICD for Waste Feed. ${ }^{3}$ The settling rate of $0.03 \mathrm{feet} / \mathrm{min}$ is specified in note 2, under Table 6 on page 18 in ICD-19. Currently, WTP is not responsible for measuring or controlling this criterion but this is the responsibility of the TOC. Therefore, SRNL has not been requested to support WTP waste qualification efforts on this issue. If the current plan does change, SRNL will develop a technique with WTP and/or tank farm representatives to determine if this settling rate can be determined (or satisfied) using simple settling tests. It should be noted that SRNL will also discuss with WTP potential concerns with HLW streams (non-Newtonian systems), since this item is presently an open item listed in Appendix D of ICD-19.

At the SRS, settling rates are not measured but rather the interface between the solids and liquid are monitored using a turbidity meter. SRS then sets the transfer jet heights based on these interface levels with some added conservatism.

\subsubsection{Qualification Efforts for LAW and HLW Glass}

A critical part of the WTP waste qualification process is to ensure that the LAW and HLW glass that is produced will meet both process and product performance constraints. In simplistic terms, this qualification step will utilize the most recent LAW and HLW glass algorithms to calculate the amounts and types of glass forming materials to be mixed with both the LAW and HLW feed streams. Once the glass formers are added to each, the mixtures will be heated to produce glass products which will ultimately be analyzed via laser ablation coupled with Inductively Coupled Plasma - Atomic Emission Spectroscopy (ICP-AES) and ICP-MS. The compositional analyses of the glasses will then be used as input into the glass algorithms and various process and product performance properties will be predicted to demonstrate the acceptability of both the LAW and HLW campaigns being qualified. It should be noted that no formal experimental work with the fabricated glass (i.e., measuring durability on the fabricated glass) is planned as part of the WTP waste qualification process.

There are similarities in the WTP approach and the activities that SRNL performs in support of the qualification of each DWPF sludge batch. These include using glass algorithms to determine the glass forming material (in SRNL's case this is a pre-fabricated frit) to be added to the sludge and the waste loading to be targeted; vitrifying the frit-sludge mixture to produce a glass product; 
analyzing the glass product (using ICP-AES or -MS after glass digestion/fusion); and using the compositional analysis to predict various properties to assess acceptability with respect to critical process and product performance constraints. However, SRNL goes one more step in that it experimentally measures the durability of the HLW glass in addition to demonstrating model applicability through a composition variability study.

To support WTP's review of the waste qualification approach for LAW and HLW glass formulation and algorithm assessments, SRNL recommends the following scope as part of future activities:

- A critical review and/or comparison of the analytical techniques currently used to support both WTP and DWPF qualification or qualification efforts regarding:

o Viability and robustness

o Sample turnaround times (TAT) relative to the qualification schedule and laboratory sample loads

o Associated uncertainties and how they are integrated and/or propagated into the glass algorithms

o Potential impacts of sampling uncertainties (i.e., if fast settling samples are anticipated) on glass former addition calculations or assessments of acceptability.

- An assessment of need and/or structure to integrate critical uncertainties (which could include, but are not limited to, analytical and property measurement uncertainties) into the glass algorithms.

- Assessments of the potential impacts of compositional variation within the WTP flowsheet (for a given campaign) to be accounted for through glass former additions while maintaining contractual waste loading obligations and still producing an acceptable product.

- The applicability and validity ranges of the LAW and HLW glass property models with respect to the anticipated glass compositional regions to be processed through WTP should be addressed as part of the overarching Waste Compliance Plan (WCP) but will ultimately be tied to the methods used in the waste qualification process.

\subsection{Future Activity Requirements for Unit Operations}

In addition to the testing outlined in the above sections, the following steps will be required to define the equipment and protocols for the unit operations during qualification testing:

- Perform literature search,

- Develop analytical flow diagrams,

- Specify the sample volume,

- Finalize the integrated flowsheet and specify the material flow,

- Specify, fabricate, and configure the test apparatus for a hot cell environment,

- Develop integrated procedures for the test apparatus,

- Demonstrate the unit operations using representative simulants, and

- Package and transfer custody of the apparatus to a WTP identified location.

These items will be addressed during future activities of the program to develop WTP's waste qualification capability. Generally speaking, the items apply to all unit operations. Key considerations for the development of the WTP waste qualification program are briefly summarized below. 
To ensure that unit operations are adequately bounded and that the fabricated equipment will define the necessary parameters, extensive literature reviews should be performed considering work previously performed at SRNL, PNNL, Battelle, Hanford and the Vitreous State Laboratory (VSL). This review should include work for other sites besides WTP as applicable. The reviews need to consider identification of the parameters relevant to the particular unit operation, such as scaling factors, material flow, temperature, pressure, molarities, levels, column size, and contact time. This information will be used to specify, fabricate, and configure the unit operations apparatus and test conditions. The literature reviews will be critical in determining the current extent of knowledge (or state-of-the-art) for each unit operation and whether any subsequent developmental testing will be needed before defining the equipment and/or protocol for the WTP waste qualification program.

As part of the literature review and with consideration to the analytical requirements for the WAC/DQO, the analytical flow diagram needs to be developed across the unit operations so the analytical sequences and subsamples can be identified. This diagram will also ensure that the necessary processing parameters are obtained from the testing, and it will help to optimize the analytical sequence.

A key consideration for the waste qualification program is the amount of sample required to qualify the batch. A representative sample from the TOC will be required and then will need to be split or processed through numerous operations. Therefore, a key component of future testing will be to define/refine the sample volume required for demonstrating the unit operations while also ensuring that all analyses are performed to meet the data quality objectives and to define the processing parameters.

Preliminary flowsheets have been defined for the waste qualification process. However, the integrated flowsheet cannot be finalized until all the equipment and required sampling are defined. Therefore, an important deliverable is the integrated flowsheet.

Once all of the above requirements are defined, the equipment to be used in the waste qualification program can be identified, specified, fabricated, and tested. The designs will need to consider the ability for remote handling and operations since waste qualification will be performed on radioactive samples. Testing will need to cover the range of simulants and conditions expected in the WTP or at least the range of parameters expected for the particular equipment. As testing is performed, procedures will be defined for the unit operations and will need to be formalized so that they can be repeated by individuals not knowledgeable of the operating equipment or data requirement needs.

After all of the shake-down testing has been performed and the above information defined, the equipment can be disassembled as necessary, packaged, and shipped to WTP for use in their waste qualification testing. 


\subsection{References}

1. "Hanford Tank Waste Treatment and Immobilization Plant, Feed Qualification, IEWO M0SRV00028, Amendment 15, Scope of Work and Technical Requirements," Richland, Washington, SCT-M0SRV00028-00-007, Revision 0, 2011.

2. A.V. Arakali, D.L. Banning, P.A. Benson, and D.A. Greer, "Initial Data Quality Objectives for WTP Feed Acceptance Criteria," Bechtel, Richland, Washington, 24590WTP-RPT-MGT-11-014, Revision 0, 2011.

3. J.W. Olson, "ICD 19 - Interface Control Document for Waste Feed," Waste Treatment Plant, Richland, Washington, 24590-WTP-ICD-MG-01-019, Revision 5, 2011.

4. C.J. Coleman, M.S. Hay, and K.B. Martin, "Compositing and Characterization of Samples from Hanford Tank 241-AY-102 / C-106," Westinghouse Savannah River Company, Aiken, South Carolina, WSRC-TR-2003-00205, 2003.

5. A.V. Arakali, D. Blumenkranz, J.L. Meehan, L.A. Huffman, and J. Yokel, "Regualtory Data Quality Objectives Optimization Report," River Protection Project, Waste Treatment Plant, 24590-WTP-RPT-MGT-04-001, Revision 0, 2004.

6. E. Slaathaug, "Specification 12 - Procedure to Determine the Waste Feed Treatment Approach," Bechtel, River Protection Project, Waste Treatment Plant, Richland, Washington, 24590-WTP-RPT-PET-11-002, Revision A, 2011.

7. $\quad$ M.E. Stone and Z.F. Qureshi, "Preliminary Evaluation of Waste Feed Pilot Evaporation Tests," Savannah River National Laboratory, Aiken, South Carolina, SRT-RPP-2003000182, Revision 0, 2003.

8. J.E. Joseph, M.E. Stone, T.B. Calloway, R.E. Eibling, C.B. Barnes, and E.K. Hansen, "Treated Law Feed Evaporation: Physical Properties and Solubility Determination," Savannah River National Laboratory, Aiken, South Carolina, SRT-RPP-2003-00039, Revision 0, 2003.

9. M.E. Stone, T.B. Calloway, F.F. Fondeur, and E.K. Hansen, "Waste Feed Evaporation: Physical Properties and Solubility Determination," Savannah River National Laboratory, Aiken, South Carolina, SRT-RPP-2003-00094, Revision 0, 2003.

10. A. Nikolov, D. Wasan, and K. Vijayaraghavan, "Final Report on Subcontract No.: AC29929N: Foaming in Hanford RPP-WTP Law Evaporation Processes," Illinois Institute of Technology, 2003.

11. C. Paperiello, "Classification of Hanford Low-Activity Waste Fraction," Office of Nuclear Materials Safety and Safeguards, United States Department of Energy, 1997.

12. W.R. Wilmarth, V.H. Dukes, J.T. Mills, F.F. Fondeur, C.C. DiPrete, and D.P. DiPrete, "Optimization Study for Strontium and Actinide Removal from 241-AN-107 Supernate" Savannah River National Laboratory, Aiken, South Carolina, WSRC-TR-2002-00258, September 18, 2002. 
13. I.Z. Stone, "Flowsheet Bases, Assumptions, and Requirements," 24590-WTP-RPT-PT02-005, Revision 5, 2009.

14. J.C. Jain, D.A. Dodd, and A.V. Arakali, "Plan for WTP Feed Pre-Qualification," 24590WTP-PL-OP-07-0001, Revision 1, 2008. 
SRNL-STI-2011-00724

Revision 0

Appendix A. Tables of WAC-DQO Parameters, Proposed Analytical Methods, and SRNL Review 
Table A-1. Review of WAC-DQO “Action Limits” Worksheet

\begin{tabular}{|c|c|c|c|c|c|c|c|c|}
\hline \multirow[b]{2}{*}{ Number } & \multirow[b]{2}{*}{$\begin{array}{l}\text { WTP WAC } \\
\text { Parameter }\end{array}$} & \multirow{2}{*}{$\begin{array}{l}\text { WTP Proposed } \\
\text { Analytical } \\
\text { Methodology }\end{array}$} & \multirow{2}{*}{$\begin{array}{l}\text { WTP Suggested } \\
\text { Analytical } \\
\text { Methods } \\
\text { (Reference Only) }\end{array}$} & \multirow{2}{*}{$\begin{array}{l}\text { WTP Suggested } \\
\text { Sample } \\
\text { Preparations } \\
\text { (Reference Only) }\end{array}$} & \multirow[b]{2}{*}{ SRNL Review Comments ${ }^{1}$} & \multicolumn{3}{|c|}{$\begin{array}{c}\text { SRNL Assessment of WTP } \\
\text { Proposed Analytical Methodology }\end{array}$} \\
\hline & & & & & & Concur & $\begin{array}{c}\text { Proposed } \\
\text { Alternative }\end{array}$ & $\begin{array}{c}\text { Remains } \\
\text { GAP }\end{array}$ \\
\hline 1 & $\begin{array}{l}\text { Bulk } \\
\text { Density } \rho \\
(\mathrm{kg} / \mathrm{L})\end{array}$ & Bulk Density & LA-519-132 & N/A & $\begin{array}{l}\text { Agree with bulk density } \\
\text { analysis. Other analysis are not } \\
\text { required and sample can be used } \\
\text { for other analysis if solids can be } \\
\text { recovered. }\end{array}$ & $X$ & & \\
\hline 2 & $\begin{array}{l}\text { Waste Feed } \\
\qquad \mathrm{pH}\end{array}$ & $\mathrm{pH}$ & $\begin{array}{l}\text { LA-212-106 } \\
\text { LA-212-105 }\end{array}$ & N/A & $\begin{array}{l}\text { Agree with the method presented } \\
\text { in LA-212-106 for both HLW } \\
\text { and LAW samples, which are } \\
\text { fluids. }\end{array}$ & $\mathrm{X}$ & & \\
\hline 3 & $\begin{array}{l}\text { Maximum } \\
\text { Solids } \mathrm{C}_{\mathrm{wt}} \\
\quad(\mathrm{wt} \%)\end{array}$ & Percent Solids & LA-564-101 & N/A & $\begin{array}{l}\text { Concur with the method of } \\
\text { measuring solids concentration. }\end{array}$ & $X$ & & \\
\hline 4 & $\begin{array}{l}\text { Maximum } \\
\text { Solids }(g / L)\end{array}$ & $\begin{array}{l}\text { Total Suspended } \\
\text { Solids }\end{array}$ & LA-512-106 & N/A & $\begin{array}{l}\text { Method is sound and is } \\
\text { consistent with SRNL approach. }\end{array}$ & $\mathrm{X}$ & & \\
\hline 5 & $\begin{array}{l}\text { Feed Unit } \\
\text { Dose }\end{array}$ & $\begin{array}{c}\text { WTP } \\
\text { Methodology. } \\
\text { Calculations } \\
\text { Based on Source } \\
\text { Terms }^{2}\end{array}$ & Calculations & N/A & Concur & $X$ & & \\
\hline
\end{tabular}




\begin{tabular}{|c|c|c|c|c|c|c|c|c|}
\hline \multirow[b]{2}{*}{ Number } & \multirow[b]{2}{*}{$\begin{array}{l}\text { WTP WAC } \\
\text { Parameter }\end{array}$} & \multirow{2}{*}{$\begin{array}{l}\text { WTP Proposed } \\
\text { Analytical } \\
\text { Methodology }\end{array}$} & \multirow{2}{*}{$\begin{array}{l}\text { WTP Suggested } \\
\text { Analytical } \\
\text { Methods } \\
\text { (Reference Only) }\end{array}$} & \multirow{2}{*}{$\begin{array}{l}\text { WTP Suggested } \\
\text { Sample } \\
\text { Preparations } \\
\text { (Reference Only) }\end{array}$} & \multirow[b]{2}{*}{ SRNL Review Comments ${ }^{1}$} & \multicolumn{3}{|c|}{$\begin{array}{c}\text { SRNL Assessment of WTP } \\
\text { Proposed Analytical Methodology }\end{array}$} \\
\hline & & & & & & Concur & $\begin{array}{c}\text { Proposed } \\
\text { Alternative }\end{array}$ & $\begin{array}{l}\text { Remains } \\
\text { GAP }\end{array}$ \\
\hline $6 a$ & $\begin{array}{c}\text { Slurry } \\
\text { Viscosity (at } \\
\left.25^{\circ} \mathrm{C}\right) \\
- \\
\text { Consistency } \\
\text { (cP) }\end{array}$ & Rheology 3,4 & ATS-LT-519-108 & N/A & See comment below (6a) & $X$ & & \\
\hline $6 \mathrm{~b}$ & $\begin{array}{c}\text { Slurry } \\
\text { Viscosity (at } \\
\left.25^{\circ} \mathrm{C}\right) \\
- \text { Yield stress } \\
\text { (Pa) }\end{array}$ & Rheology ${ }^{3,4}$ & ATS-LT-519-108 & N/A & $\begin{array}{l}\text { ATS-LT-519-108_AO_222-S } \\
\text { has been recommended, which } \\
\text { utilizes a smaller sample than } \\
\text { the Haake rheometer, but may } \\
\text { have some differences that need } \\
\text { to be addressed. }\end{array}$ & $X$ & & \\
\hline 7 & $\begin{array}{l}\mathrm{NH}_{3} \text { (Free } \\
\text { Ammonia) }\end{array}$ & $\mathrm{NH}_{3}$ & LA-544-112 & N/A & $\begin{array}{c}\text { Method identified is acceptable. } \\
0.5 \mathrm{ml} \text { sample will have } \\
\text { detection limit of } 2 \mathrm{mg} / \mathrm{L} \text {. ICD- } \\
19 \text { revision requires }<0.04 \mathrm{M} \text { or }< \\
680 \mathrm{mg} / \mathrm{L}\end{array}$ & $X$ & & \\
\hline 8 & $\begin{array}{c}\text { No } \\
\text { Separable } \\
\text { Organics } \\
\end{array}$ & $\begin{array}{l}\text { Organic Layer } \\
\text { Determination }^{5}\end{array}$ & LA-519-151 & $\mathrm{N} / \mathrm{A}$ & $\begin{array}{c}\text { Visual observation is adequate. } \\
\text { Sampling is key for this } \\
\text { parameter. }\end{array}$ & $X$ & & \\
\hline 9 & $\begin{array}{l}\text { Polychlorina } \\
\text { ted } \\
\text { Biphenyls } \\
\text { (PCBs) } \\
\text { [WTP } \\
\text { permit, C- } \\
\text { 2a(1) and C- }\end{array}$ & $\begin{array}{c}\text { PCBs } \\
\text { (See Appendix } \\
\text { A-4 Items \#234- } \\
240)\end{array}$ & $\begin{array}{l}\text { (See Appendix A-4 } \\
\text { Items \#234-240) }\end{array}$ & $\begin{array}{l}\text { (See Appendix A-4 } \\
\text { Items \#234-240) }\end{array}$ & & $\mathrm{X}$ & & \\
\hline
\end{tabular}




\begin{tabular}{|c|c|c|c|c|c|c|c|c|}
\hline \multirow[b]{2}{*}{ Number } & \multirow{2}{*}{$\begin{array}{l}\text { WTP WAC } \\
\text { Parameter }\end{array}$} & \multirow{2}{*}{$\begin{array}{l}\text { WTP Proposed } \\
\text { Analytical } \\
\text { Methodology }{ }^{1}\end{array}$} & \multirow{2}{*}{$\begin{array}{l}\text { WTP Suggested } \\
\text { Analytical } \\
\text { Methods } \\
\text { (Reference Only) }\end{array}$} & \multirow{2}{*}{$\begin{array}{l}\text { WTP Suggested } \\
\text { Sample } \\
\text { Preparations } \\
\text { (Reference Only) }\end{array}$} & \multirow[b]{2}{*}{ SRNL Review Comments ${ }^{1}$} & \multicolumn{3}{|c|}{$\begin{array}{c}\text { SRNL Assessment of WTP } \\
\text { Proposed Analytical Methodology }\end{array}$} \\
\hline & & & & & & Concur & $\begin{array}{c}\text { Proposed } \\
\text { Alternative }\end{array}$ & $\begin{array}{l}\text { Remains } \\
\text { GAP }\end{array}$ \\
\hline & $\begin{array}{c}2 \mathrm{a}(2)] \\
\text { (Arochlors) }\end{array}$ & & & & & & & \\
\hline 10 & $\begin{array}{c}\text { Total } \\
\text { Organic } \\
\text { Carbon } \\
\text { (TOC) } \\
\text { [WTP } \\
\text { permit, C- } \\
\text { 2a(1), C- } \\
\text { 2a(2), and } \\
\text { Table 3a(3)] }\end{array}$ & $\begin{array}{c}\text { Carbon } \\
\text { Determination }\end{array}$ & LA-342-100 & $\mathrm{N} / \mathrm{A}$ & $\begin{array}{l}\text { Total inorganic carbon - total } \\
\text { organic carbon has given us } \\
\text { problems from } 2 \text { perspectives a) } \\
\text { reproducible sampling and 2) } \\
\text { some of the organics are } \\
\text { destroyed at higher temperatures } \\
\text { than we can achieve with our } \\
\text { instrument. We use grinding to } \\
\text { overcome sampling issues. } \\
\text { Temperature profile of the WTP } \\
\text { system may need to be } \\
\text { evaluated. }\end{array}$ & $\mathrm{X}$ & & \\
\hline 11 & $\begin{array}{l}\text { Pu to Metals } \\
\text { Loading } \\
\text { Ratio }\end{array}$ & $\begin{array}{c}\text { Total } \mathrm{Pu} / \\
(\mathrm{Fe}+\mathrm{Cd}+\mathrm{Ni}+ \\
\mathrm{Mn}) \\
\text { ICP-AES } \\
\text { ICP-MS } \\
\text { AEA } \\
\text { LSC }\end{array}$ & $\begin{array}{c}\text { (See Appendix A-2 } \\
\text { Items \#61, 42, 31, } \\
52, \& 48)\end{array}$ & $\begin{array}{c}\text { (See Appendix A-2 } \\
\text { Items \#61, } 42,31 \\
52, \& 48)\end{array}$ & Concur & $\mathrm{X}$ & & \\
\hline 12 & $\begin{array}{c}\mathrm{U}_{\text {Fissile }} \text { to } \\
\mathrm{U}_{\text {Total }} \text { Ratio }\end{array}$ & $\begin{array}{c}\left({ }^{233} \mathrm{U}+{ }^{235} \mathrm{U}\right) / \\
\left({ }^{233} \mathrm{U}+{ }^{235} \mathrm{U}\right. \\
\left.+{ }^{238} \mathrm{U}\right) \\
\text { ICP-MS } \\
\text { AEA }\end{array}$ & $\begin{array}{c}\text { (See Appendix A-3 } \\
\text { Items \#124, } 126, \& \\
128)\end{array}$ & $\begin{array}{c}\text { (See Appendix A-3 } \\
\text { Items \#124, } 126, \& \text {, } \\
128)\end{array}$ & Concur & $\mathrm{X}$ & & \\
\hline 13 & $\begin{array}{c}\mathrm{Pu} \\
\text { Concentratio } \\
\mathrm{n} \text { of Liquids } \\
6\end{array}$ & $\begin{array}{l}\text { Pu Isotopes } \\
\text { ICP-MS } \\
\text { AEA } \\
\text { LSC }\end{array}$ & $\begin{array}{l}\text { (See Appendix A-2 } \\
\text { Item \#61) }\end{array}$ & $\begin{array}{l}\text { (See Appendix A-2 } \\
\text { Item \#61) }\end{array}$ & & $\mathrm{X}$ & & \\
\hline 14 & Na Molarity & ICP-AES & $\begin{array}{l}\text { (See Appendix A-2 } \\
\text { Item \#50) }\end{array}$ & $\begin{array}{l}\text { (See Appendix A-2 } \\
\text { Item \#50) }\end{array}$ & Concur & $\mathrm{X}$ & & \\
\hline
\end{tabular}




\begin{tabular}{|c|c|c|c|c|c|c|c|c|}
\hline \multirow[b]{2}{*}{ Number } & \multirow[b]{2}{*}{$\begin{array}{l}\text { WTP WAC } \\
\text { Parameter }\end{array}$} & \multirow{2}{*}{$\begin{array}{l}\text { WTP Proposed } \\
\text { Analytical } \\
\text { Methodology }\end{array}$} & \multirow{2}{*}{$\begin{array}{l}\text { WTP Suggested } \\
\text { Analytical } \\
\text { Methods } \\
\text { (Reference Only) }\end{array}$} & \multirow{2}{*}{$\begin{array}{c}\text { WTP Suggested } \\
\text { Sample } \\
\text { Preparations } \\
\text { (Reference Only) }\end{array}$} & \multirow[b]{2}{*}{ SRNL Review Comments ${ }^{1}$} & \multicolumn{3}{|c|}{$\begin{array}{c}\text { SRNL Assessment of WTP } \\
\text { Proposed Analytical Methodology }\end{array}$} \\
\hline & & & & & & Concur & $\begin{array}{l}\text { Proposed } \\
\text { Alternative }\end{array}$ & $\begin{array}{l}\text { Remains } \\
\text { GAP }\end{array}$ \\
\hline 15 & $\begin{array}{l}\text { Hydrogen } \\
\text { Generation } \\
\text { Rate }\end{array}$ & $\begin{array}{l}\text { Hydrogen } \\
\text { GC-TCD }\end{array}$ & ATS-LT-523-163 & N/A & $\begin{array}{l}\text { The recommended technique for } \\
\text { measurement of HGR is a } \\
\text { continuous flow system with a } \\
\text { small air purge. Hydrogen } \\
\text { generation is measured with } \\
\text { online gas analysis instruments } \\
\text { installed on the offgas line. It is } \\
\text { not certain that the detection } \\
\text { limits of the online gas analyzers } \\
\text { are sufficient to allow this } \\
\text { technique to be utilized, } \\
\text { therefore, HGR has been } \\
\text { identified as a "gap". }\end{array}$ & & & $\mathrm{X}$ \\
\hline 16 & $\begin{array}{c}\text { Feed } \\
\text { Temperature } \\
\text { (in-tank) }\end{array}$ & $\begin{array}{c}\text { In-Line } \\
\text { Measurement }{ }^{7}\end{array}$ & $\begin{array}{c}\text { In-tank or Flow } \\
\text { Loop } \\
\text { Measurement }\end{array}$ & N/A & & $\mathrm{X}$ & & \\
\hline 17 & $\begin{array}{c}\text { Critical } \\
\text { Velocity } \mathrm{V}_{\mathrm{cr}} \\
\text { (ft/s) } \\
\text { [in a } \\
\text { nominal } 3 \\
\text { inch } \\
\text { diameter } \\
\text { pipe, (in- } \\
\text { tank) ] }\end{array}$ & $\begin{array}{c}\text { In-Line } \\
\text { Measurement }{ }^{7}\end{array}$ & $\begin{array}{l}\text { Flow Loop } \\
\text { Measurement }\end{array}$ & N/A & $\begin{array}{l}\text { Assumption being made is that } \\
\text { critical velocity applies to } \\
\text { transfer of feed from tank farm } \\
\text { to receipt vessel - not through } \\
\text { WTP. }\end{array}$ & & & $\mathrm{X}$ \\
\hline 18 & $\begin{array}{l}\text { Temperature } \\
\text { Change } \\
\text { (Waste Feed } \\
\text { Compatibilit } \\
\text { y) }\end{array}$ & Compatibility & $\begin{array}{l}\text { ASTM Method } \\
5058-90^{8}\end{array}$ & N/A & & $\mathrm{X}$ & & \\
\hline
\end{tabular}




\section{${ }^{1}$ Notes}

AEA: alpha energy analysis

ASTM: American Society for Testing and Materials

DWP: Dangerous Waste Permit

DQO: data quality objective

DSA: documented safety analysis

GC-TCD: gas chromatography - thermal conductivity detector

HGR: hydrogen generation rate

HLW: high-level waste

ICD: interface control document

ICP-AES: inductively coupled plasma - atomic emission spectroscopy

ICP-MS: inductively coupled plasma - mass spectroscopy

LAW: low-activity waste

LSC: liquid scintillation counting

N/A: not applicable

PCB: polychlorinated biphenyl

SRNL: Savannah River National Laboratory

TOC: Tank Operations Contractor

TSAP: tank sampling and analysis plan

ULD: unit liter dose

WAC: waste acceptance criteria

WTP: Hanford Tank Waste Treatment and Immobilization Plant

${ }^{2}$ Note: Radiological unit dose is part of TOC evaluation for feed transfer. TOC will report ULD values using tank farm waste source terms. The projected values are documented in WTP DSA under assumptions 10-12, 24590-WTP-Z0C-W14T-00020

${ }^{3}$ Note: Malvern Bohlin Rheometer uses smaller sample size

${ }^{4}$ Note: WTP uses Section 5.6 of 24590-WTP-GPG-RTD-001 to determine yield stress and consistency. A flow curve of shear stress vs shear rate is developed using the bob and cup or cone and plate methods. The resulting plot is fit to the Bingham Plastic Model. The slope of the line is consistency; the y intercept is yield stress (otherwise known as the Bingham Yield Stress or the Bingham Plastic Yield Index)

${ }^{5}$ Note: Visual inspection of tank waste samples required per TSAP

${ }^{6}$ Note: Not required if $\mathrm{Pu}$ is determined in liquids for $\# 11$

${ }^{7}$ Note: Method under development by TOC

${ }^{8}$ Note: WTP DWP requires testing on $10 \mathrm{~mL}$ volume of feed sample with $10 \mathrm{~mL}$ sample from previous campaign 
Table A-2. Review of WAC-DQO “Elemental” Worksheet

\begin{tabular}{|c|c|c|c|c|c|c|c|c|}
\hline \multirow{2}{*}{ Number } & \multirow{2}{*}{$\begin{array}{c}\text { WTP } \\
\text { Processability } \\
\text { Parameter }\end{array}$} & \multirow{2}{*}{$\begin{array}{l}\text { WTP Proposed } \\
\text { Analytical } \\
\text { Methodology }\end{array}$} & \multirow{2}{*}{$\begin{array}{l}\text { WTP Suggested } \\
\text { Analytical } \\
\text { Methods } \\
\text { (Reference Only) }\end{array}$} & \multirow{2}{*}{$\begin{array}{c}\text { WTP Suggested } \\
\text { Sample } \\
\text { Preparations } \\
\text { (Reference Only) }\end{array}$} & \multirow{2}{*}{ SRNL Review Comments ${ }^{1}$} & \multicolumn{3}{|c|}{$\begin{array}{c}\text { SRNL Assessment of WTP } \\
\text { Proposed } \\
\text { Analytical Methodology }\end{array}$} \\
\hline & & & & & & Concur & $\begin{array}{l}\text { Proposed } \\
\text { Alternative }\end{array}$ & $\begin{array}{l}\text { Remains } \\
\text { GAP }\end{array}$ \\
\hline 19 & $\begin{array}{c}\text { Total } \\
\text { Radioactive } \\
\text { Material Fed to } \\
\text { WTP per Year } \\
\text { from External } \\
\text { Sources }\end{array}$ & $\begin{array}{l}\text { WTP } \\
\text { Methodology. } \\
\text { Dependant upon } \\
\text { the reported } \\
\text { radionuclide } \\
\text { concentration in } \\
\text { staged HLW and } \\
\text { LAW feed. }\end{array}$ & Calculation & N/A & & $\mathrm{X}$ & & \\
\hline 20 & Abrasivity & $\begin{array}{l}\text { Abrasivity is an } \\
\text { ICD-19 } \\
\text { requirement. } \\
\text { Method } \\
\text { development to } \\
\text { be consistent } \\
\text { with phenomena } \\
\text { of interest. }\end{array}$ & To Be Developed & To Be Developed & $\begin{array}{l}\text { Work with WTP to develop } \\
\text { method for shielded cells }\end{array}$ & & & $\mathrm{X}$ \\
\hline 21 & $\mathrm{Ag}$ & $\begin{array}{l}\text { ICP-AES } \\
\text { ICP-MS }\end{array}$ & $\begin{array}{l}\text { LA-505-161 } \\
\text { LA-506-102 }\end{array}$ & $\begin{array}{l}\text { LA-504-101 } \\
\text { LA-505-112 } \\
\text { LA-505-114 } \\
\text { LA-505-158 } \\
\text { LA-505-163 }\end{array}$ & $\begin{array}{c}\text { Need to ensure dissolution } \\
\text { will solubilize Ag without } \\
\text { precipitation. }\end{array}$ & $\mathrm{X}$ & & \\
\hline 22 & $\mathrm{Al}$ & $\begin{array}{l}\text { ICP-AES } \\
\text { ICP-MS }^{2}\end{array}$ & $\begin{array}{l}\text { LA-505-161 } \\
\text { LA-506-102 }\end{array}$ & $\begin{array}{l}\text { LA-504-101 } \\
\text { LA-505-112 } \\
\text { LA-505-114 } \\
\text { LA-505-158 } \\
\text { LA-505-163 }\end{array}$ & $\begin{array}{l}\text { Boehmite may have a } \\
\text { problem with digestion. } \\
\text { Suggest peroxide fusion. }\end{array}$ & $\mathrm{X}$ & & \\
\hline
\end{tabular}




\begin{tabular}{|c|c|c|c|c|c|c|c|c|}
\hline \multirow{2}{*}{ Number } & \multirow{2}{*}{$\begin{array}{c}\text { WTP } \\
\text { Processability } \\
\text { Parameter }\end{array}$} & \multirow{2}{*}{$\begin{array}{l}\text { WTP Proposed } \\
\text { Analytical } \\
\text { Methodology }\end{array}$} & \multirow{2}{*}{$\begin{array}{l}\text { WTP Suggested } \\
\text { Analytical } \\
\text { Methods } \\
\text { (Reference Only) }\end{array}$} & \multirow{2}{*}{$\begin{array}{c}\text { WTP Suggested } \\
\text { Sample } \\
\text { Preparations } \\
\text { (Reference Only) }\end{array}$} & \multirow{2}{*}{ SRNL Review Comments ${ }^{1}$} & \multicolumn{3}{|c|}{$\begin{array}{c}\text { SRNL Assessment of WTP } \\
\text { Proposed } \\
\text { Analytical Methodology } \\
\end{array}$} \\
\hline & & & & & & Concur & $\begin{array}{c}\text { Proposed } \\
\text { Alternative }\end{array}$ & $\begin{array}{c}\text { Remains } \\
\text { GAP }\end{array}$ \\
\hline 23 & As & $\begin{array}{l}\text { ICP-AES } \\
\text { ICP-MS } \\
\text { AAS }\end{array}$ & $\begin{array}{c}\text { EPA } 7062 \\
\text { LA-505-161 } \\
\text { LA-506-102 } \\
\text { LA-325-106 }\end{array}$ & $\begin{array}{l}\text { LA-504-101 } \\
\text { LA-505-112 } \\
\text { LA-505-114 } \\
\text { LA-505-158 } \\
\text { LA-505-163 }\end{array}$ & $\begin{array}{l}\text { Hydride generation/flame } \\
\text { AAS is recommended. }\end{array}$ & $X$ & & \\
\hline 24 & B & $\begin{array}{l}\text { ICP-AES } \\
\text { ICP-MS }\end{array}$ & $\begin{array}{l}\text { LA-505-161 } \\
\text { LA-506-102 }\end{array}$ & $\begin{array}{l}\text { LA-504-101 } \\
\text { LA-505-112 } \\
\text { LA-505-114 } \\
\text { LA-505-158 } \\
\text { LA-505-163 }\end{array}$ & Concur & $X$ & & \\
\hline 25 & $\mathrm{Ba}$ & $\begin{array}{l}\text { ICP-AES } \\
\text { ICP-MS }\end{array}$ & $\begin{array}{l}\text { LA-505-161 } \\
\text { LA-506-102 }\end{array}$ & $\begin{array}{l}\text { LA-504-101 } \\
\text { LA-505-112 } \\
\text { LA-505-114 } \\
\text { LA-505-158 } \\
\text { LA-505-163 }\end{array}$ & Concur & $\mathrm{X}$ & & \\
\hline 26 & $\mathrm{Be}$ & $\begin{array}{l}\text { ICP-AES } \\
\text { ICP-MS }\end{array}$ & $\begin{array}{l}\text { LA-505-161 } \\
\text { LA-506-102 }\end{array}$ & $\begin{array}{l}\text { LA-504-101 } \\
\text { LA-505-112 } \\
\text { LA-505-114 } \\
\text { LA-505-158 } \\
\text { LA-505-163 } \\
\text { LA-549-141 }\end{array}$ & $\begin{array}{l}\text { Peroxide fusion may be } \\
\text { needed for some forms of } \\
\text { beryllium oxide. }\end{array}$ & $\mathrm{X}$ & & \\
\hline 27 & $\mathrm{Bi}$ & $\begin{array}{l}\text { ICP-AES } \\
\text { ICP-MS }^{2}\end{array}$ & $\begin{array}{l}\text { LA-505-161 } \\
\text { LA-506-102 }\end{array}$ & $\begin{array}{l}\text { LA-504-101 } \\
\text { LA-505-112 } \\
\text { LA-505-114 } \\
\text { LA-505-158 } \\
\text { LA-505-163 } \\
\text { LA-549-142 }\end{array}$ & $\begin{array}{l}\text { Peroxide fusion may be } \\
\text { needed for dissolution. }\end{array}$ & $\mathrm{X}$ & & \\
\hline 28 & Bromide & IC & LA-533-115 & N/A & $\begin{array}{c}\text { Assume two measurements } \\
\text { for slurry sample - liquid and } \\
\text { leach of solids. }\end{array}$ & $\mathrm{X}$ & & \\
\hline
\end{tabular}




\begin{tabular}{|c|c|c|c|c|c|c|c|c|}
\hline \multirow{2}{*}{ Number } & \multirow{2}{*}{$\begin{array}{c}\text { WTP } \\
\text { Processability } \\
\text { Parameter }\end{array}$} & \multirow{2}{*}{$\begin{array}{l}\text { WTP Proposed } \\
\text { Analytical } \\
\text { Methodology }\end{array}$} & \multirow{2}{*}{$\begin{array}{l}\text { WTP Suggested } \\
\text { Analytical } \\
\text { Methods } \\
\text { (Reference Only) }\end{array}$} & \multirow{2}{*}{$\begin{array}{c}\text { WTP Suggested } \\
\text { Sample } \\
\text { Preparations } \\
\text { (Reference Only) }\end{array}$} & \multirow{2}{*}{ SRNL Review Comments ${ }^{1}$} & \multicolumn{3}{|c|}{$\begin{array}{c}\text { SRNL Assessment of WTP } \\
\text { Proposed } \\
\text { Analytical Methodology } \\
\end{array}$} \\
\hline & & & & & & Concur & $\begin{array}{c}\text { Proposed } \\
\text { Alternative }\end{array}$ & $\begin{array}{c}\text { Remains } \\
\text { GAP }\end{array}$ \\
\hline 29 & $\mathrm{Ca}$ & $\begin{array}{l}\text { ICP-AES } \\
\text { ICP-MS }\end{array}$ & $\begin{array}{l}\text { LA-505-161 } \\
\text { LA-506-102 }\end{array}$ & $\begin{array}{l}\text { LA-504-101 } \\
\text { LA-505-112 } \\
\text { LA-505-114 } \\
\text { LA-505-158 } \\
\text { LA-505-163 }\end{array}$ & Concur & $\mathrm{X}$ & & \\
\hline 30 & $\mathrm{Ce}$ & $\begin{array}{l}\text { ICP-AES } \\
\text { ICP-MS }\end{array}$ & $\begin{array}{l}\text { LA-505-161 } \\
\text { LA-506-102 }\end{array}$ & $\begin{array}{l}\text { LA-504-101 } \\
\text { LA-505-112 } \\
\text { LA-505-114 } \\
\text { LA-505-158 } \\
\text { LA-505-163 }\end{array}$ & Concur & $\mathrm{X}$ & & \\
\hline 31 & $\mathrm{Cd}$ & $\begin{array}{l}\text { ICP-AES } \\
\text { ICP-MS }\end{array}$ & $\begin{array}{l}\text { LA-505-161 } \\
\text { LA-506-102 }\end{array}$ & $\begin{array}{l}\text { LA-504-101 } \\
\text { LA-505-112 } \\
\text { LA-505-114 } \\
\text { LA-505-158 } \\
\text { LA-505-163 }\end{array}$ & Concur & $\mathrm{X}$ & & \\
\hline 32 & Chloride & IC & LA-533-115 & N/A & $\begin{array}{l}\text { Assume two measurements } \\
\text { for slurry sample - liquid and } \\
\text { leach of solids. }\end{array}$ & $\mathrm{X}$ & & \\
\hline 33 & $\mathrm{Cl}$ & $\begin{array}{l}\text { Will be measured } \\
\text { as chloride ion } \\
\text { (See Item \#32) }\end{array}$ & $\mathrm{N} / \mathrm{A}$ & $\mathrm{N} / \mathrm{A}$ & $\begin{array}{l}\text { Propose elimination of } \\
\text { elemental chlorine. Not a } \\
\text { typical process } \\
\text { measurement. }\end{array}$ & $\mathrm{X}$ & & \\
\hline 34 & $\mathrm{Co}$ & $\begin{array}{l}\text { ICP-AES } \\
\text { ICP-MS }\end{array}$ & $\begin{array}{l}\text { LA-505-161 } \\
\text { LA-506-102 }\end{array}$ & $\begin{array}{l}\text { LA-504-101 } \\
\text { LA-505-112 } \\
\text { LA-505-114 } \\
\text { LA-505-158 } \\
\text { LA-505-163 }\end{array}$ & Concur - suggest MS & $\mathrm{X}$ & & \\
\hline
\end{tabular}




\begin{tabular}{|c|c|c|c|c|c|c|c|c|}
\hline \multirow{2}{*}{ Number } & \multirow{2}{*}{$\begin{array}{c}\text { WTP } \\
\text { Processability } \\
\text { Parameter }\end{array}$} & \multirow{2}{*}{$\begin{array}{l}\text { WTP Proposed } \\
\text { Analytical } \\
\text { Methodology }\end{array}$} & \multirow{2}{*}{$\begin{array}{l}\text { WTP Suggested } \\
\text { Analytical } \\
\text { Methods } \\
\text { (Reference Only) }\end{array}$} & \multirow{2}{*}{$\begin{array}{c}\text { WTP Suggested } \\
\text { Sample } \\
\text { Preparations } \\
\text { (Reference Only) }\end{array}$} & \multirow{2}{*}{ SRNL Review Comments ${ }^{1}$} & \multicolumn{3}{|c|}{$\begin{array}{c}\text { SRNL Assessment of WTP } \\
\text { Proposed } \\
\text { Analytical Methodology } \\
\end{array}$} \\
\hline & & & & & & Concur & $\begin{array}{c}\text { Proposed } \\
\text { Alternative }\end{array}$ & $\begin{array}{c}\text { Remains } \\
\text { GAP }\end{array}$ \\
\hline 35 & $\mathrm{CO}_{3}^{-2}$ & $\begin{array}{l}\text { Total Carbon } \\
\text { (Total Inorganic } \\
\text { Carbon / } \\
\text { Total Organic } \\
\text { Carbon) }\end{array}$ & LA-342-100 & N/A & $\begin{array}{l}\text { Concur - need to ensure } \\
\text { good sampling for total } \\
\text { inorganic carbon - total } \\
\text { organic carbon with slurry } \\
\text { samples. }\end{array}$ & $\mathrm{X}$ & & \\
\hline 36 & $\mathrm{CN}$ & Cyanide & LA-695-102 & N/A & Procedure seems appropriate & $\mathrm{X}$ & & \\
\hline 37 & $\mathrm{Cr}$ & $\begin{array}{l}\text { ICP-AES } \\
\text { ICP-MS }\end{array}$ & $\begin{array}{l}\text { LA-505-161 } \\
\text { LA-506-102 }\end{array}$ & $\begin{array}{l}\text { LA-504-101 } \\
\text { LA-505-112 } \\
\text { LA-505-114 } \\
\text { LA-505-158 } \\
\text { LA-505-163 }\end{array}$ & Concur & $\mathrm{X}$ & & \\
\hline 38 & Cs & ICP-MS & LA-506-102 & $\begin{array}{l}\text { LA-504-101 } \\
\text { LA-505-112 } \\
\text { LA-505-114 } \\
\text { LA-505-158 } \\
\text { LA-505-163 }\end{array}$ & Concur with ICP-MS. & $\mathrm{X}$ & & \\
\hline 39 & $\mathrm{Cu}$ & $\begin{array}{l}\text { ICP-AES } \\
\text { ICP-MS }^{2}\end{array}$ & $\begin{array}{l}\text { LA-505-161 } \\
\text { LA-506-102 }\end{array}$ & $\begin{array}{l}\text { LA-504-101 } \\
\text { LA-505-112 } \\
\text { LA-505-114 } \\
\text { LA-505-158 } \\
\text { LA-505-163 } \\
\end{array}$ & Concur & $\mathrm{X}$ & & \\
\hline 40 & $\mathrm{~F}$ & $\begin{array}{l}\text { Will be measured } \\
\text { as fluoride ion } \\
\text { (See Item \#41) }\end{array}$ & N/A & $\mathrm{N} / \mathrm{A}$ & $\begin{array}{l}\text { Propose elimination of } \\
\text { elemental fluorine. Not a } \\
\text { typical process } \\
\text { measurement. }\end{array}$ & $\mathrm{X}$ & & \\
\hline
\end{tabular}




\begin{tabular}{|c|c|c|c|c|c|c|c|c|}
\hline \multirow{2}{*}{ Number } & \multirow{2}{*}{$\begin{array}{c}\text { WTP } \\
\text { Processability } \\
\text { Parameter }\end{array}$} & \multirow{2}{*}{$\begin{array}{l}\text { WTP Proposed } \\
\text { Analytical } \\
\text { Methodology }\end{array}$} & \multirow{2}{*}{$\begin{array}{l}\text { WTP Suggested } \\
\text { Analytical } \\
\text { Methods } \\
\text { (Reference Only) }\end{array}$} & \multirow{2}{*}{$\begin{array}{c}\text { WTP Suggested } \\
\text { Sample } \\
\text { Preparations } \\
\text { (Reference Only) }\end{array}$} & \multirow{2}{*}{ SRNL Review Comments ${ }^{1}$} & \multicolumn{3}{|c|}{$\begin{array}{c}\text { SRNL Assessment of WTP } \\
\text { Proposed } \\
\text { Analytical Methodology } \\
\end{array}$} \\
\hline & & & & & & Concur & $\begin{array}{c}\text { Proposed } \\
\text { Alternative }\end{array}$ & $\begin{array}{l}\text { Remains } \\
\text { GAP }\end{array}$ \\
\hline 41 & Fluoride & IC & LA-533-115 & N/A & $\begin{array}{l}\text { Assume two measurements } \\
\text { for slurry sample - liquid and } \\
\text { leach of solids. }\end{array}$ & $\mathrm{X}$ & & \\
\hline 42 & $\mathrm{Fe}$ & $\begin{array}{l}\text { ICP-AES } \\
\text { ICP-MS }\end{array}$ & $\begin{array}{l}\text { LA-505-161 } \\
\text { LA-506-102 }\end{array}$ & $\begin{array}{l}\text { LA-504-101 } \\
\text { LA-505-112 } \\
\text { LA-505-114 } \\
\text { LA-505-158 } \\
\text { LA-505-163 }\end{array}$ & Concur & $\mathrm{X}$ & & \\
\hline 43 & $\mathrm{Hg}$ & CVAA & LA-325-106 & N/A & $\begin{array}{l}\text { Need to ensure dissolution } \\
\text { can be done in radiohood } \\
\text { considering potential dose } \\
\text { rates of samples. }\end{array}$ & $\mathrm{X}$ & & \\
\hline 44 & $\mathrm{~K}$ & $\begin{array}{l}\text { ICP-AES } \\
\text { ICP-MS }^{2}\end{array}$ & $\begin{array}{l}\text { LA-505-161 } \\
\text { LA-506-102 }\end{array}$ & $\begin{array}{l}\text { LA-504-101 } \\
\text { LA-505-112 } \\
\text { LA-505-114 } \\
\text { LA-505-158 } \\
\text { LA-505-163 }\end{array}$ & Concur & $\mathrm{X}$ & & \\
\hline 45 & $\mathrm{La}$ & $\begin{array}{l}\text { ICP-AES } \\
\text { ICP-MS }\end{array}$ & $\begin{array}{l}\text { LA-505-161 } \\
\text { LA-506-102 }\end{array}$ & $\begin{array}{c}\text { LA-504-101 } \\
\text { LA-505-112 } \\
\text { LA-505-114 } \\
\text { LA-505-158 } \\
\text { LA-505-163 } \\
\text { LA-549-141 } \\
\text { LA-549-142 } \\
\text { WV-1906 }\end{array}$ & $\begin{array}{l}\text { Assume dissolution will be } \\
\text { appropriate for this element. }\end{array}$ & $\mathrm{X}$ & & \\
\hline 46 & $\mathrm{Li}$ & $\begin{array}{l}\text { ICP-AES } \\
\text { ICP-MS }\end{array}$ & $\begin{array}{l}\text { LA-505-161 } \\
\text { LA-506-102 }\end{array}$ & $\begin{array}{l}\text { LA-504-101 } \\
\text { LA-505-112 } \\
\text { LA-505-114 } \\
\text { LA-505-158 } \\
\text { LA-505-163 }\end{array}$ & Concur & $\mathrm{X}$ & & \\
\hline
\end{tabular}




\begin{tabular}{|c|c|c|c|c|c|c|c|c|}
\hline \multirow{2}{*}{ Number } & \multirow{2}{*}{$\begin{array}{c}\text { WTP } \\
\text { Processability } \\
\text { Parameter }\end{array}$} & \multirow{2}{*}{$\begin{array}{l}\text { WTP Proposed } \\
\text { Analytical } \\
\text { Methodology }\end{array}$} & \multirow{2}{*}{$\begin{array}{l}\text { WTP Suggested } \\
\text { Analytical } \\
\text { Methods } \\
\text { (Reference Only) }\end{array}$} & \multirow{2}{*}{$\begin{array}{c}\text { WTP Suggested } \\
\text { Sample } \\
\text { Preparations } \\
\text { (Reference Only) }\end{array}$} & \multirow{2}{*}{ SRNL Review Comments ${ }^{1}$} & \multicolumn{3}{|c|}{$\begin{array}{c}\text { SRNL Assessment of WTP } \\
\text { Proposed } \\
\text { Analytical Methodology } \\
\end{array}$} \\
\hline & & & & & & Concur & $\begin{array}{c}\text { Proposed } \\
\text { Alternative }\end{array}$ & $\begin{array}{l}\text { Remains } \\
\text { GAP }\end{array}$ \\
\hline 47 & $\mathrm{Mg}$ & $\begin{array}{l}\text { ICP-AES } \\
\text { ICP-MS }\end{array}$ & $\begin{array}{l}\text { LA-505-161 } \\
\text { LA-506-102 }\end{array}$ & $\begin{array}{l}\text { LA-504-101 } \\
\text { LA-505-112 } \\
\text { LA-505-114 } \\
\text { LA-505-158 } \\
\text { LA-505-163 }\end{array}$ & Concur & $\mathrm{X}$ & & \\
\hline 48 & $\mathrm{Mn}$ & $\begin{array}{l}\text { ICP-AES } \\
\text { ICP-MS }\end{array}$ & $\begin{array}{l}\text { LA-505-161 } \\
\text { LA-506-102 }\end{array}$ & $\begin{array}{l}\text { LA-504-101 } \\
\text { LA-505-112 } \\
\text { LA-505-114 } \\
\text { LA-505-158 } \\
\text { LA-505-163 }\end{array}$ & Concur & $\mathrm{X}$ & & \\
\hline 49 & Mo & $\begin{array}{l}\text { ICP-AES } \\
\text { ICP-MS }\end{array}$ & $\begin{array}{l}\text { LA-505-161 } \\
\text { LA-506-102 }\end{array}$ & $\begin{array}{l}\text { LA-504-101 } \\
\text { LA-505-112 } \\
\text { LA-505-114 } \\
\text { LA-505-158 } \\
\text { LA-505-163 }\end{array}$ & Concur & $\mathrm{X}$ & & \\
\hline 50 & $\mathrm{Na}$ & ICP-AES & LA-505-161 & $\begin{array}{l}\text { LA-504-101 } \\
\text { LA-505-112 } \\
\text { LA-505-114 } \\
\text { LA-505-158 } \\
\text { LA-505-163 }\end{array}$ & Concur & $\mathrm{X}$ & & \\
\hline 51 & $\mathrm{Nd}$ & $\begin{array}{l}\text { ICP-AES } \\
\text { ICP-MS }^{2}\end{array}$ & $\begin{array}{l}\text { LA-505-161 } \\
\text { LA-506-102 }\end{array}$ & $\begin{array}{l}\text { LA-504-101 } \\
\text { LA-505-112 } \\
\text { LA-505-114 } \\
\text { LA-505-158 } \\
\text { LA-505-163 } \\
\text { LA-549-141 } \\
\text { LA-549-142 } \\
\text { WV-1906 }\end{array}$ & $\begin{array}{l}\text { Assume dissolution will be } \\
\text { identified for this element. }\end{array}$ & $\mathrm{X}$ & & \\
\hline 52 & $\mathrm{Ni}$ & $\begin{array}{l}\text { ICP-AES } \\
\text { ICP-MS }^{2}\end{array}$ & $\begin{array}{l}\text { LA-505-161 } \\
\text { LA-506-102 }\end{array}$ & $\begin{array}{l}\text { LA-504-101 } \\
\text { LA-505-112 } \\
\text { LA-505-114 } \\
\text { LA-505-158 } \\
\text { LA-505-163 }\end{array}$ & Concur & $\mathrm{X}$ & & \\
\hline
\end{tabular}




\begin{tabular}{|c|c|c|c|c|c|c|c|c|}
\hline \multirow{2}{*}{ Number } & \multirow{2}{*}{$\begin{array}{c}\text { WTP } \\
\text { Processability } \\
\text { Parameter }\end{array}$} & \multirow{2}{*}{$\begin{array}{l}\text { WTP Proposed } \\
\text { Analytical } \\
\text { Methodology }\end{array}$} & \multirow{2}{*}{$\begin{array}{l}\text { WTP Suggested } \\
\text { Analytical } \\
\text { Methods } \\
\text { (Reference Only) }\end{array}$} & \multirow{2}{*}{$\begin{array}{c}\text { WTP Suggested } \\
\text { Sample } \\
\text { Preparations } \\
\text { (Reference Only) }\end{array}$} & \multirow{2}{*}{ SRNL Review Comments ${ }^{1}$} & \multicolumn{3}{|c|}{$\begin{array}{c}\text { SRNL Assessment of WTP } \\
\text { Proposed } \\
\text { Analytical Methodology }\end{array}$} \\
\hline & & & & & & Concur & $\begin{array}{c}\text { Proposed } \\
\text { Alternative }\end{array}$ & $\begin{array}{c}\text { Remains } \\
\text { GAP }\end{array}$ \\
\hline 53 & $\mathrm{NO}_{2}^{-}$(Nitrite) & IC & LA-533-115 & N/A & $\begin{array}{c}\text { Assume two measurements } \\
\text { for slurry sample - liquid and } \\
\text { leach of solids. }\end{array}$ & $X$ & & \\
\hline 54 & $\mathrm{NO}_{3}{ }^{-}$(Nitrate) & IC & LA-533-115 & N/A & $\begin{array}{l}\text { Assume two measurements } \\
\text { for slurry sample - liquid and } \\
\text { leach of solids. }\end{array}$ & $X$ & & \\
\hline 55 & $\mathrm{P}$ & $\begin{array}{l}\text { ICP-AES } \\
\text { ICP-MS }\end{array}$ & $\begin{array}{l}\text { LA-505-161 } \\
\text { LA-506-102 }\end{array}$ & $\begin{array}{l}\text { LA-504-101 } \\
\text { LA-505-112 } \\
\text { LA-505-114 } \\
\text { LA-505-158 } \\
\text { LA-505-163 }\end{array}$ & $\begin{array}{c}\text { Concur. } \\
\text { Typically use ICP-AES. }\end{array}$ & $X$ & & \\
\hline 56 & $\mathrm{~Pb}$ & $\begin{array}{l}\text { ICP-AES } \\
\text { ICP-MS }^{2}\end{array}$ & $\begin{array}{l}\text { LA-505-161 } \\
\text { LA-506-102 }\end{array}$ & $\begin{array}{l}\text { LA-504-101 } \\
\text { LA-505-112 } \\
\text { LA-505-114 } \\
\text { LA-505-158 } \\
\text { LA-505-163 }\end{array}$ & Concur & $\mathrm{X}$ & & \\
\hline 57 & $\mathrm{Pd}$ & $\begin{array}{l}\text { ICP-AES } \\
\text { ICP-MS }^{2}\end{array}$ & $\begin{array}{l}\text { LA-505-161 } \\
\text { LA-506-102 }\end{array}$ & $\begin{array}{c}\text { LA-504-101 } \\
\text { LA-505-112 } \\
\text { LA-505-114 } \\
\text { LA-505-158 } \\
\text { LA-505-163 } \\
\text { LA-549-141 } \\
\text { LA-549-142 } \\
\text { WV-1906 }\end{array}$ & $\begin{array}{l}\text { Assume dissolution will be } \\
\text { identified for this element. }\end{array}$ & $X$ & & \\
\hline
\end{tabular}




\begin{tabular}{|c|c|c|c|c|c|c|c|c|}
\hline \multirow{2}{*}{ Number } & \multirow{2}{*}{$\begin{array}{c}\text { WTP } \\
\text { Processability } \\
\text { Parameter }\end{array}$} & \multirow{2}{*}{$\begin{array}{l}\text { WTP Proposed } \\
\text { Analytical } \\
\text { Methodology }\end{array}$} & \multirow{2}{*}{$\begin{array}{l}\text { WTP Suggested } \\
\text { Analytical } \\
\text { Methods } \\
\text { (Reference Only) }\end{array}$} & \multirow{2}{*}{$\begin{array}{c}\text { WTP Suggested } \\
\text { Sample } \\
\text { Preparations } \\
\text { (Reference Only) }\end{array}$} & \multirow{2}{*}{ SRNL Review Comments ${ }^{1}$} & \multicolumn{3}{|c|}{$\begin{array}{c}\text { SRNL Assessment of WTP } \\
\text { Proposed } \\
\text { Analytical Methodology } \\
\end{array}$} \\
\hline & & & & & & Concur & $\begin{array}{l}\text { Proposed } \\
\text { Alternative }\end{array}$ & $\begin{array}{l}\text { Remains } \\
\text { GAP }\end{array}$ \\
\hline 58 & $\begin{array}{c}\mathrm{PO}_{4} \\
\text { (Phosphate) }\end{array}$ & IC & LA-533-115 & N/A & $\begin{array}{l}\text { See ion chromatography } \\
\text { note on Cl- }\end{array}$ & $\mathrm{X}$ & & \\
\hline 59 & $\operatorname{Pr}$ & $\begin{array}{l}\text { ICP-AES } \\
\text { ICP-MS }\end{array}$ & $\begin{array}{l}\text { LA-505-161 } \\
\text { LA-506-102 }\end{array}$ & $\begin{array}{l}\text { LA-504-101 } \\
\text { LA-505-112 } \\
\text { LA-505-114 } \\
\text { LA-505-158 } \\
\text { LA-505-163 }\end{array}$ & Concur & $\mathrm{X}$ & & \\
\hline 60 & $\mathrm{Pu}$ & $\begin{array}{l}\text { ICP-AES }^{3} \\
\text { ICP-MS }\end{array}$ & $\begin{array}{l}\text { LA-505-161 } \\
\text { LA-506-102 }\end{array}$ & $\begin{array}{l}\text { LA-504-101 } \\
\text { LA-505-112 } \\
\text { LA-505-114 } \\
\text { LA-505-158 } \\
\text { LA-505-163 } \\
\text { LA-549-141 } \\
\text { LA-549-142 } \\
\text { WV-1906 }\end{array}$ & $\begin{array}{l}\text { Fusion or use of HF is likely } \\
\text { necessary for dissolution. }\end{array}$ & $\mathrm{X}$ & & \\
\hline 61 & $\mathrm{Pu}$ Isotopes & $\begin{array}{l}\text { ICP-MS and/or } \\
\text { AEA Counting } \\
\text { Measurements } \\
\text { Summation for } \\
\text { Isotopes }\end{array}$ & $\begin{array}{c}\text { Calculation } \\
\text { (See Items \#106 - } \\
\# 109)\end{array}$ & N/A & & $\mathrm{X}$ & & \\
\hline 62 & $\mathrm{Rb}$ & $\begin{array}{l}\text { ICP-AES } \\
\text { ICP-MS }\end{array}$ & $\begin{array}{l}\text { LA-505-161 } \\
\text { LA-506-102 }\end{array}$ & $\begin{array}{l}\text { LA-504-101 } \\
\text { LA-505-112 } \\
\text { LA-505-114 } \\
\text { LA-505-158 } \\
\text { LA-505-163 }\end{array}$ & Concur & $\mathrm{X}$ & & \\
\hline
\end{tabular}




\begin{tabular}{|c|c|c|c|c|c|c|c|c|}
\hline \multirow{2}{*}{ Number } & \multirow{2}{*}{$\begin{array}{c}\text { WTP } \\
\text { Processability } \\
\text { Parameter }\end{array}$} & \multirow{2}{*}{$\begin{array}{l}\text { WTP Proposed } \\
\text { Analytical } \\
\text { Methodology }\end{array}$} & \multirow{2}{*}{$\begin{array}{l}\text { WTP Suggested } \\
\text { Analytical } \\
\text { Methods } \\
\text { (Reference Only) }\end{array}$} & \multirow{2}{*}{$\begin{array}{c}\text { WTP Suggested } \\
\text { Sample } \\
\text { Preparations } \\
\text { (Reference Only) }\end{array}$} & \multirow{2}{*}{ SRNL Review Comments ${ }^{1}$} & \multicolumn{3}{|c|}{$\begin{array}{c}\text { SRNL Assessment of WTP } \\
\text { Proposed } \\
\text { Analytical Methodology } \\
\end{array}$} \\
\hline & & & & & & Concur & $\begin{array}{c}\text { Proposed } \\
\text { Alternative }\end{array}$ & $\begin{array}{c}\text { Remains } \\
\text { GAP }\end{array}$ \\
\hline 63 & $\mathrm{Rh}$ & $\begin{array}{c}\text { ICP-AES } \\
\text { ICP-MS }\end{array}$ & $\begin{array}{l}\text { LA-505-161 } \\
\text { LA-506-102 }\end{array}$ & $\begin{array}{l}\text { LA-504-101 } \\
\text { LA-505-112 } \\
\text { LA-505-114 } \\
\text { LA-505-158 } \\
\text { LA-505-163 } \\
\text { LA-549-141 } \\
\text { LA-549-142 }\end{array}$ & $\begin{array}{l}\text { More aggressive dissolution } \\
\text { (fusion) is likely necessary } \\
\text { for } \mathrm{Rh} \text { and } \mathrm{Ru} \text {. }\end{array}$ & $X$ & & \\
\hline 64 & $\mathrm{Ru}$ & $\begin{array}{c}\text { ICP-AES } \\
\text { ICP-MS }\end{array}$ & $\begin{array}{l}\text { LA-505-161 } \\
\text { LA-506-102 }\end{array}$ & $\begin{array}{l}\text { LA-504-101 } \\
\text { LA-505-112 } \\
\text { LA-505-114 } \\
\text { LA-505-158 } \\
\text { LA-505-163 } \\
\text { LA-549-141 } \\
\text { LA-549-142 } \\
\end{array}$ & $\begin{array}{l}\text { More aggressive dissolution } \\
\text { (fusion) is likely necessary } \\
\text { for } \mathrm{Rh} \text { and } \mathrm{Ru} \text {. }\end{array}$ & $X$ & & \\
\hline 65 & $\mathrm{~S}$ & $\begin{array}{l}\text { ICP-AES } \\
\text { ICP-MS }^{2}\end{array}$ & $\begin{array}{l}\text { LA-505-161 } \\
\text { LA-506-102 }\end{array}$ & $\begin{array}{l}\text { LA-504-101 } \\
\text { LA-505-112 } \\
\text { LA-505-114 } \\
\text { LA-505-158 } \\
\text { LA-505-163 }\end{array}$ & Concur & $X$ & & \\
\hline 66 & $\mathrm{Sb}$ & $\begin{array}{l}\text { ICP-AES } \\
\text { ICP-MS }^{2}\end{array}$ & $\begin{array}{l}\text { LA-505-161 } \\
\text { LA-506-102 }\end{array}$ & $\begin{array}{l}\text { LA-504-101 } \\
\text { LA-505-112 } \\
\text { LA-505-114 } \\
\text { LA-505-158 } \\
\text { LA-505-163 } \\
\end{array}$ & Concur & $\mathrm{X}$ & & \\
\hline 67 & $\mathrm{Se}$ & $\begin{array}{l}\text { ICP-AES } \\
\text { ICP-MS } \\
\text { AAS }\end{array}$ & $\begin{array}{c}\text { EPA } 7742 \\
\text { LA-505-161 } \\
\text { LA-506-102 } \\
\text { LA-325-106 }\end{array}$ & $\begin{array}{l}\text { LA-504-101 } \\
\text { LA-505-112 } \\
\text { LA-505-114 } \\
\text { LA-505-158 } \\
\text { LA-505-163 }\end{array}$ & $\begin{array}{l}\text { Same as for As - hydride } \\
\text { generation/flame AAS is } \\
\text { recommended. }\end{array}$ & $X$ & & \\
\hline
\end{tabular}




\begin{tabular}{|c|c|c|c|c|c|c|c|c|}
\hline \multirow{2}{*}{ Number } & \multirow{2}{*}{$\begin{array}{c}\text { WTP } \\
\text { Processability } \\
\text { Parameter }\end{array}$} & \multirow{2}{*}{$\begin{array}{l}\text { WTP Proposed } \\
\text { Analytical } \\
\text { Methodology }\end{array}$} & \multirow{2}{*}{$\begin{array}{l}\text { WTP Suggested } \\
\text { Analytical } \\
\text { Methods } \\
\text { (Reference Only) }\end{array}$} & \multirow{2}{*}{$\begin{array}{c}\text { WTP Suggested } \\
\text { Sample } \\
\text { Preparations } \\
\text { (Reference Only) }\end{array}$} & \multirow{2}{*}{ SRNL Review Comments ${ }^{1}$} & \multicolumn{3}{|c|}{$\begin{array}{c}\text { SRNL Assessment of WTP } \\
\text { Proposed } \\
\text { Analytical Methodology }\end{array}$} \\
\hline & & & & & & Concur & $\begin{array}{c}\text { Proposed } \\
\text { Alternative }\end{array}$ & $\begin{array}{l}\text { Remains } \\
\text { GAP }\end{array}$ \\
\hline 68 & $\mathrm{Si}$ & $\begin{array}{l}\text { ICP-AES } \\
\text { ICP-MS }^{2}\end{array}$ & $\begin{array}{l}\text { LA-505-161 } \\
\text { LA-506-102 }\end{array}$ & $\begin{array}{c}\text { LA-504-101 } \\
\text { LA-505-112 } \\
\text { LA-505-114 } \\
\text { LA-505-158 } \\
\text { LA-505-163 } \\
\text { LA-549-141 } \\
\text { LA-549-142 } \\
\text { WV-1906 }\end{array}$ & $\begin{array}{l}\text { Fusion or use of HF is likely } \\
\text { necessary for dissolution. }\end{array}$ & $\mathrm{X}$ & & \\
\hline 69 & Sn & $\begin{array}{l}\text { ICP-AES } \\
\text { ICP-MS }\end{array}$ & $\begin{array}{l}\text { LA-505-161 } \\
\text { LA-506-102 }\end{array}$ & $\begin{array}{l}\text { LA-504-101 } \\
\text { LA-505-112 } \\
\text { LA-505-114 } \\
\text { LA-505-158 } \\
\text { LA-505-163 } \\
\text { LA-549-141 } \\
\text { LA-549-142 } \\
\text { WV-1906 }\end{array}$ & $\begin{array}{l}\text { Assume dissolution will be } \\
\text { identified for this element. }\end{array}$ & $\mathrm{X}$ & & \\
\hline 70 & $\mathrm{SO}_{4}$ (Sulfate) & IC & LA-533-115 & $\mathrm{N} / \mathrm{A}$ & $\begin{array}{l}\text { Assume two measurements } \\
\text { for slurry sample - liquid and } \\
\text { leach of solids. }\end{array}$ & $X$ & & \\
\hline 71 & $\mathrm{Sr}$ & $\begin{array}{l}\text { ICP-AES } \\
\text { ICP-MS }^{2}\end{array}$ & $\begin{array}{l}\text { LA-505-161 } \\
\text { LA-506-102 }\end{array}$ & $\begin{array}{l}\text { LA-504-101 } \\
\text { LA-505-112 } \\
\text { LA-505-114 } \\
\text { LA-505-158 } \\
\text { LA-505-163 }\end{array}$ & Concur & $\mathrm{X}$ & & \\
\hline
\end{tabular}




\begin{tabular}{|c|c|c|c|c|c|c|c|c|}
\hline \multirow{2}{*}{ Number } & \multirow{2}{*}{$\begin{array}{c}\text { WTP } \\
\text { Processability } \\
\text { Parameter }\end{array}$} & \multirow{2}{*}{$\begin{array}{l}\text { WTP Proposed } \\
\text { Analytical } \\
\text { Methodology }\end{array}$} & \multirow{2}{*}{$\begin{array}{l}\text { WTP Suggested } \\
\text { Analytical } \\
\text { Methods } \\
\text { (Reference Only) }\end{array}$} & \multirow{2}{*}{$\begin{array}{c}\text { WTP Suggested } \\
\text { Sample } \\
\text { Preparations } \\
\text { (Reference Only) }\end{array}$} & \multirow{2}{*}{ SRNL Review Comments ${ }^{1}$} & \multicolumn{3}{|c|}{$\begin{array}{c}\text { SRNL Assessment of WTP } \\
\text { Proposed } \\
\text { Analytical Methodology } \\
\end{array}$} \\
\hline & & & & & & Concur & $\begin{array}{c}\text { Proposed } \\
\text { Alternative }\end{array}$ & $\begin{array}{l}\text { Remains } \\
\text { GAP }\end{array}$ \\
\hline 72 & $\mathrm{Ta}$ & $\begin{array}{l}\text { ICP-AES } \\
\text { ICP-MS }\end{array}$ & $\begin{array}{l}\text { LA-505-161 } \\
\text { LA-506-102 }\end{array}$ & $\begin{array}{l}\text { LA-504-101 } \\
\text { LA-505-112 } \\
\text { LA-505-114 } \\
\text { LA-505-158 } \\
\text { LA-505-163 } \\
\text { LA-549-141 } \\
\text { LA-549-142 } \\
\text { WV-1906 }\end{array}$ & $\begin{array}{l}\text { Fusion or use of HF is likely } \\
\text { necessary for dissolution. }\end{array}$ & $X$ & & \\
\hline 73 & $\mathrm{Tc}$ & ICP-MS & LA-506-102 & $\begin{array}{l}\text { LA-504-101 } \\
\text { LA-505-112 } \\
\text { LA-505-114 } \\
\text { LA-505-158 } \\
\text { LA-505-163 }\end{array}$ & $\begin{array}{l}\text { Concur. Typically use ICP- } \\
\text { MS. May want to consider } \\
\text { radiochemical separation } \\
\text { and beta counting, in certain } \\
\text { cases. }\end{array}$ & $\mathrm{X}$ & & \\
\hline 74 & $\mathrm{Te}$ & $\begin{array}{l}\text { ICP-AES } \\
\text { ICP-MS }\end{array}$ & $\begin{array}{l}\text { LA-505-161 } \\
\text { LA-506-102 }\end{array}$ & $\begin{array}{l}\text { LA-504-101 } \\
\text { LA-505-112 } \\
\text { LA-505-114 } \\
\text { LA-505-158 } \\
\text { LA-505-163 }\end{array}$ & $\begin{array}{l}\text { Assume dissolution will be } \\
\text { identified for this element. }\end{array}$ & $\mathrm{X}$ & & \\
\hline 75 & Th & $\begin{array}{l}\text { ICP-AES } \\
\text { ICP-MS }\end{array}$ & $\begin{array}{l}\text { LA-505-161 } \\
\text { LA-506-102 }\end{array}$ & $\begin{array}{l}\text { LA-504-101 } \\
\text { LA-505-112 } \\
\text { LA-505-114 } \\
\text { LA-505-158 } \\
\text { LA-505-163 } \\
\text { LA-549-141 } \\
\text { LA-549-142 } \\
\text { WV-1906 }\end{array}$ & $\begin{array}{l}\text { Fusion or use of HF is likely } \\
\text { necessary for dissolution. }\end{array}$ & $\mathrm{X}$ & & \\
\hline 76 & $\mathrm{Ti}$ & $\begin{array}{l}\text { ICP-AES } \\
\text { ICP-MS }^{2}\end{array}$ & $\begin{array}{l}\text { LA-505-161 } \\
\text { LA-506-102 }\end{array}$ & $\begin{array}{l}\text { LA-504-101 } \\
\text { LA-505-112 } \\
\text { LA-505-114 } \\
\text { LA-505-158 } \\
\text { LA-505-163 } \\
\text { LA-549-141 } \\
\text { LA-549-142 }\end{array}$ & $\begin{array}{l}\text { Assume dissolution will be } \\
\text { identified for this element. }\end{array}$ & $\mathrm{X}$ & & \\
\hline
\end{tabular}




\begin{tabular}{|c|c|c|c|c|c|c|c|c|}
\hline \multirow{2}{*}{ Number } & \multirow{2}{*}{$\begin{array}{c}\text { WTP } \\
\text { Processability } \\
\text { Parameter }\end{array}$} & \multirow{2}{*}{$\begin{array}{l}\text { WTP Proposed } \\
\text { Analytical } \\
\text { Methodology }\end{array}$} & \multirow{2}{*}{$\begin{array}{l}\text { WTP Suggested } \\
\text { Analytical } \\
\text { Methods } \\
\text { (Reference Only) }\end{array}$} & \multirow{2}{*}{$\begin{array}{l}\text { WTP Suggested } \\
\text { Sample } \\
\text { Preparations } \\
\text { (Reference Only) }\end{array}$} & \multirow{2}{*}{ SRNL Review Comments ${ }^{1}$} & \multicolumn{3}{|c|}{$\begin{array}{c}\text { SRNL Assessment of WTP } \\
\text { Proposed } \\
\text { Analytical Methodology }\end{array}$} \\
\hline & & & & & & Concur & $\begin{array}{l}\text { Proposed } \\
\text { Alternative }\end{array}$ & $\begin{array}{c}\text { Remains } \\
\text { GAP }\end{array}$ \\
\hline 76.1 & $\mathrm{Tl}$ & $\begin{array}{l}\text { ICP-AES } \\
\text { ICP-MS }\end{array}$ & $\begin{array}{l}\text { LA-505-161 } \\
\text { LA-506-102 }\end{array}$ & $\begin{array}{l}\text { LA-504-101 } \\
\text { LA-505-112 } \\
\text { LA-505-114 } \\
\text { LA-505-158 } \\
\text { LA-505-163 } \\
\end{array}$ & & $X$ & & \\
\hline 77 & $\begin{array}{c}\text { Total } \\
\text { Inorganic } \\
\text { Carbon } \\
\left(\text { Same as } \mathrm{CO}_{3}^{2-}\right. \\
\text { ) }\end{array}$ & $\begin{array}{l}\text { Total Carbon } \\
\text { (Total Inorganic } \\
\text { Carbon / } \\
\text { Total Organic } \\
\text { Carbon) }\end{array}$ & LA-342-100 & N/A & $\begin{array}{l}\text { Concur - need to ensure } \\
\text { good sampling for total } \\
\text { inorganic carbon / total } \\
\text { organic carbon with slurry } \\
\text { samples. }\end{array}$ & $\mathrm{X}$ & & \\
\hline 78 & $\mathrm{U}$ & $\begin{array}{l}\text { ICP-AES } \\
\text { ICP-MS }\end{array}$ & $\begin{array}{l}\text { LA-505-161 } \\
\text { LA-506-102 }\end{array}$ & $\begin{array}{l}\text { LA-504-101 } \\
\text { LA-505-112 } \\
\text { LA-505-114 } \\
\text { LA-505-158 } \\
\text { LA-505-163 } \\
\text { LA-549-141 } \\
\text { LA-549-142 }\end{array}$ & $\begin{array}{l}\text { Suggest fusion for all } \\
\text { actinides, including U. }\end{array}$ & $\mathrm{X}$ & & \\
\hline 79 & U Isotopes & $\begin{array}{l}\text { ICP-MS and/or } \\
\text { Counting } \\
\text { Measurements } \\
\text { Summation for } \\
\text { Isotopes }\end{array}$ & $\begin{array}{c}\text { Calculation } \\
\text { (See Items \#123- } \\
\# 128)\end{array}$ & N/A & $\begin{array}{l}\text { See individual isotope } \\
\text { comments }\end{array}$ & $\mathrm{X}$ & & \\
\hline 80 & $\mathrm{~V}$ & $\begin{array}{l}\text { ICP-AES } \\
\text { ICP-MS }\end{array}$ & $\begin{array}{l}\text { LA-505-161 } \\
\text { LA-506-102 }\end{array}$ & $\begin{array}{l}\text { LA-504-101 } \\
\text { LA-505-112 } \\
\text { LA-505-114 } \\
\text { LA-505-158 } \\
\text { LA-505-163 }\end{array}$ & Concur & $\mathrm{X}$ & & \\
\hline
\end{tabular}




\begin{tabular}{|c|c|c|c|c|c|c|c|c|}
\hline \multirow{2}{*}{ Number } & \multirow{2}{*}{$\begin{array}{c}\text { WTP } \\
\text { Processability } \\
\text { Parameter }\end{array}$} & \multirow{2}{*}{$\begin{array}{l}\text { WTP Proposed } \\
\text { Analytical } \\
\text { Methodology }\end{array}$} & \multirow{2}{*}{$\begin{array}{l}\text { WTP Suggested } \\
\text { Analytical } \\
\text { Methods } \\
\text { (Reference Only) }\end{array}$} & \multirow{2}{*}{$\begin{array}{c}\text { WTP Suggested } \\
\text { Sample } \\
\text { Preparations } \\
\text { (Reference Only) }\end{array}$} & \multirow{2}{*}{ SRNL Review Comments ${ }^{1}$} & \multicolumn{3}{|c|}{$\begin{array}{c}\text { SRNL Assessment of WTP } \\
\text { Proposed } \\
\text { Analytical Methodology } \\
\end{array}$} \\
\hline & & & & & & Concur & $\begin{array}{c}\text { Proposed } \\
\text { Alternative }\end{array}$ & $\begin{array}{l}\text { Remains } \\
\text { GAP }\end{array}$ \\
\hline 81 & W & $\begin{array}{l}\text { ICP-AES } \\
\text { ICP-MS }\end{array}$ & $\begin{array}{l}\text { LA-505-161 } \\
\text { LA-506-102 }\end{array}$ & $\begin{array}{c}\text { LA-504-101 } \\
\text { LA-505-112 } \\
\text { LA-505-114 } \\
\text { LA-505-158 } \\
\text { LA-505-163 } \\
\text { LA-549-141 } \\
\text { LA-549-142 } \\
\text { WV-1906 } \\
\end{array}$ & $\begin{array}{l}\text { Fusion or use of HF is likely } \\
\text { necessary for dissolution. }\end{array}$ & $X$ & & \\
\hline 82 & $\mathrm{Y}$ & $\begin{array}{l}\text { ICP-AES } \\
\text { ICP-MS }\end{array}$ & $\begin{array}{l}\text { LA-505-161 } \\
\text { LA-506-102 }\end{array}$ & $\begin{array}{l}\text { LA-504-101 } \\
\text { LA-505-112 } \\
\text { LA-505-114 } \\
\text { LA-505-158 } \\
\text { LA-505-163 }\end{array}$ & $\begin{array}{l}\text { Concur. Assume Y not used } \\
\text { as internal standard }\end{array}$ & $X$ & & \\
\hline 83 & $\mathrm{Zn}$ & $\begin{array}{l}\text { ICP-AES } \\
\text { ICP-MS }^{2}\end{array}$ & $\begin{array}{l}\text { LA-505-161 } \\
\text { LA-506-102 }\end{array}$ & $\begin{array}{l}\text { LA-504-101 } \\
\text { LA-505-112 } \\
\text { LA-505-114 } \\
\text { LA-505-158 } \\
\text { LA-505-163 }\end{array}$ & Concur & $\mathrm{X}$ & & \\
\hline 84.1 & $\mathrm{Zr}$ & $\begin{array}{l}\text { ICP-AES } \\
\text { ICP-MS }\end{array}$ & $\begin{array}{l}\text { LA-505-161 } \\
\text { LA-506-102 }\end{array}$ & $\begin{array}{c}\text { LA-504-101 } \\
\text { LA-505-112 } \\
\text { LA-505-114 } \\
\text { LA-505-158 } \\
\text { LA-505-163 } \\
\text { WV-1906 } \\
\end{array}$ & $\begin{array}{l}\text { Fusion or use of HF is likely } \\
\text { necessary for dissolution. } \\
\text { Please ensure crucibles are } \\
\text { appropriate for this element. }\end{array}$ & $X$ & & \\
\hline 84.2 & Oxalate & $\begin{array}{l}\text { Anion } \\
\text { IC }\end{array}$ & LA-533-115 & N/A & & $X$ & & \\
\hline
\end{tabular}




\section{${ }^{1}$ Note:}

AAS: atomic absorption spectroscopy

AEA: alpha energy analysis

CVAA: cold vapor atomic absorption spectrometry

DQO: data quality objective

EPA: US Environmental Protection Agency (SW-846 reference method)

HLW: high-level waste

IC: ion chromatography

ICD: interface control document

ICP-AES: inductively coupled plasma - atomic emission spectroscopy

ICP-MS: inductively coupled plasma - mass spectroscopy

LAW: low-activity waste

N/A: not applicable

SRNL: Savannah River National Laboratory

WAC: waste acceptance criteria

WTP: Hanford Tank Waste Treatment and Immobilization Plant

${ }^{2}$ Note: Need to address detection limits if ICP-MS is used

${ }^{3}$ Note: Need to address detection limits if ICP-AES is used. 
Table A-3. Review of WAC-DQO “Rad Chem” Worksheet

\begin{tabular}{|c|c|c|c|c|c|c|c|c|}
\hline \multirow{2}{*}{ Number } & \multirow{2}{*}{$\begin{array}{c}\text { WTP } \\
\text { Processability } \\
\text { Parameter }\end{array}$} & \multirow{2}{*}{$\begin{array}{l}\text { WTP Proposed } \\
\text { Analytical } \\
\text { Methodology }\end{array}$} & \multirow{2}{*}{$\begin{array}{l}\text { WTP Suggested } \\
\text { Analytical } \\
\text { Methods } \\
\text { (Reference Only) }\end{array}$} & \multirow{2}{*}{$\begin{array}{c}\text { WTP Suggested } \\
\text { Sample } \\
\text { Preparations } \\
\text { (Reference Only) }\end{array}$} & \multirow{2}{*}{ SRNL Review Comments ${ }^{1}$} & \multicolumn{3}{|c|}{$\begin{array}{c}\text { SRNL Assessment of WTP } \\
\text { Proposed } \\
\text { Analytical Methodology } \\
\end{array}$} \\
\hline & & & & & & Concur & $\begin{array}{c}\text { Proposed } \\
\text { Alternative }\end{array}$ & $\begin{array}{c}\text { Remains } \\
\text { GAP }\end{array}$ \\
\hline 85 & ${ }^{227} \mathrm{Ac}$ & $\begin{array}{c}\text { Gamma } \\
\text { GEA }\end{array}$ & LA-508-165 & LA-548-121 & $\begin{array}{c}\text { Concur, need to ensure } \\
\text { dissolution is adequate and } \\
\text { separation from other gamma } \\
\text { emitters. }\end{array}$ & $\mathrm{X}$ & & \\
\hline 86 & ${ }^{241} \mathrm{Am}$ & $\begin{array}{l}\text { Alpha } \\
\text { AEA }\end{array}$ & LA-508-166 & $\begin{array}{l}\text { LA-542-104 } \\
\text { LA-943-129 } \\
\text { LA-953-104 } \\
\end{array}$ & Concur & $X$ & & \\
\hline 87 & ${ }^{243} \mathrm{Am}$ & $\begin{array}{l}\text { Alpha } \\
\text { AEA }\end{array}$ & LA-508-166 & $\begin{array}{l}\text { LA-542-104 } \\
\text { LA-943-129 } \\
\text { LA-549-141 } \\
\text { LA-549-142 }\end{array}$ & $\begin{array}{l}\text { Ensure dissolution (suggest } \\
\text { fusion) and separations are } \\
\text { adequate. } \\
\text { LA-943-129 targets Am-241 } \\
\text { analysis and does not contain } \\
\text { sufficient details regarding Am- } \\
243 \text { analyses (spike/tracer } \\
\text { differences and calculation } \\
\text { differences). }\end{array}$ & $\mathrm{X}$ & & \\
\hline 88 & ${ }^{137 m} \mathrm{Ba}$ & $\begin{array}{c}\text { Gamma } \\
\text { GEA }\end{array}$ & LA-508-165 & LA-548-121 & Concur & $X$ & & \\
\hline 89 & ${ }^{14} \mathrm{C}$ & $\begin{array}{c}\text { Beta } \\
\text { Separate Sample }\end{array}$ & LA-508-121 & LA-348-104 & Concur & $\mathrm{X}$ & & \\
\hline 90 & ${ }^{113 \mathrm{~m}} \mathrm{Cd}$ & $\begin{array}{c}\text { Gamma } \\
\text { GEA }\end{array}$ & LA-508-165 & LA-548-121 & Concur & $X$ & & \\
\hline 91 & ${ }^{242} \mathrm{Cm}$ & $\begin{array}{l}\text { Alpha } \\
\text { AEA } \\
\text { ICP-MS }\end{array}$ & $\begin{array}{l}\text { LA-508-166 } \\
\text { LA-506-102 }\end{array}$ & $\begin{array}{l}\text { LA-943-129 } \\
\text { LA-953-104 } \\
\text { LA-549-141 } \\
\text { LA-549-142 }\end{array}$ & $\begin{array}{l}\text { Concur, need to ensure } \\
\text { dissolution (suggest fusion) and } \\
\text { separations are adequate. }\end{array}$ & $\mathrm{X}$ & & \\
\hline
\end{tabular}




\begin{tabular}{|c|c|c|c|c|c|c|c|c|}
\hline \multirow{2}{*}{ Number } & \multirow{2}{*}{$\begin{array}{c}\text { WTP } \\
\text { Processability } \\
\text { Parameter }\end{array}$} & \multirow{2}{*}{$\begin{array}{l}\text { WTP Proposed } \\
\text { Analytical } \\
\text { Methodology }\end{array}$} & \multirow{2}{*}{$\begin{array}{l}\text { WTP Suggested } \\
\text { Analytical } \\
\text { Methods } \\
\text { (Reference Only) }\end{array}$} & \multirow{2}{*}{$\begin{array}{l}\text { WTP Suggested } \\
\text { Sample } \\
\text { Preparations } \\
\text { (Reference Only) }\end{array}$} & \multirow{2}{*}{ SRNL Review Comments ${ }^{1}$} & \multicolumn{3}{|c|}{$\begin{array}{c}\text { SRNL Assessment of WTP } \\
\text { Proposed } \\
\text { Analytical Methodology } \\
\end{array}$} \\
\hline & & & & & & Concur & $\begin{array}{l}\text { Proposed } \\
\text { Alternative }\end{array}$ & $\begin{array}{c}\text { Remains } \\
\text { GAP }\end{array}$ \\
\hline 92 & ${ }^{243+244} \mathrm{Cm}$ & $\begin{array}{l}\text { Alpha } \\
\text { AEA }\end{array}$ & LA-508-166 & $\begin{array}{l}\text { LA-943-129 } \\
\text { LA-953-104 } \\
\text { LA-549-141 } \\
\text { LA-549-142 }\end{array}$ & $\begin{array}{l}\text { Concur, need to ensure } \\
\text { dissolution (suggest fusion) and } \\
\text { separations are adequate. }\end{array}$ & $\mathrm{X}$ & & \\
\hline 93 & ${ }^{60} \mathrm{Co}$ & $\begin{array}{l}\text { Gamma } \\
\text { GEA }\end{array}$ & LA-508-165 & LA-548-121 & Concur & $\mathrm{X}$ & & \\
\hline 94 & ${ }^{134} \mathrm{Cs}$ & $\begin{array}{l}\text { Gamma } \\
\text { GEA }\end{array}$ & LA-508-165 & LA-548-121 & Concur & $\mathrm{X}$ & & \\
\hline 95 & ${ }^{137} \mathrm{Cs}$ & $\begin{array}{c}\text { Gamma } \\
\text { GEA }\end{array}$ & LA-508-165 & LA-548-121 & Concur & $\mathrm{X}$ & & \\
\hline 96 & ${ }^{152} \mathrm{Eu}$ & $\begin{array}{c}\text { Gamma } \\
\text { GEA }\end{array}$ & LA-508-165 & LA-548-121 & Concur & $\mathrm{X}$ & & \\
\hline 97 & ${ }^{154} \mathrm{Eu}$ & $\begin{array}{l}\text { Gamma } \\
\text { GEA }\end{array}$ & LA-508-165 & LA-548-121 & Concur, likely needs separation. & $\mathrm{X}$ & & \\
\hline 98 & ${ }^{155} \mathrm{Eu}$ & $\begin{array}{l}\text { Gamma } \\
\text { GEA }\end{array}$ & LA-508-165 & LA-548-121 & Concur, likely needs separation. & $\mathrm{X}$ & & \\
\hline 99 & ${ }^{3} \mathrm{H}$ & $\begin{array}{l}\text { Beta } \\
\text { LSC }\end{array}$ & LA-508-121 & LA-218-111 & Concur & $\mathrm{X}$ & & \\
\hline 100 & ${ }^{129} \mathrm{I}$ & $\begin{array}{l}\text { Gamma, low } \\
\text { energy } \\
\text { GEA }\end{array}$ & LA-508-165 & N/A & Concur, likely needs separation. & $\mathrm{X}$ & & \\
\hline
\end{tabular}




\begin{tabular}{|c|c|c|c|c|c|c|c|c|}
\hline \multirow{2}{*}{ Number } & \multirow{2}{*}{$\begin{array}{c}\text { WTP } \\
\text { Processability } \\
\text { Parameter }\end{array}$} & \multirow{2}{*}{$\begin{array}{l}\text { WTP Proposed } \\
\text { Analytical } \\
\text { Methodology }\end{array}$} & \multirow{2}{*}{$\begin{array}{l}\text { WTP Suggested } \\
\text { Analytical } \\
\text { Methods } \\
\text { (Reference Only) }\end{array}$} & \multirow{2}{*}{$\begin{array}{l}\text { WTP Suggested } \\
\text { Sample } \\
\text { Preparations } \\
\text { (Reference Only) }\end{array}$} & \multirow{2}{*}{ SRNL Review Comments ${ }^{1}$} & \multicolumn{3}{|c|}{$\begin{array}{c}\text { SRNL Assessment of WTP } \\
\text { Proposed } \\
\text { Analytical Methodology } \\
\end{array}$} \\
\hline & & & & & & Concur & $\begin{array}{l}\text { Proposed } \\
\text { Alternative }\end{array}$ & $\begin{array}{c}\text { Remains } \\
\text { GAP }\end{array}$ \\
\hline 101 & ${ }^{93 \mathrm{~m}} \mathrm{Nb}$ & $\begin{array}{l}\text { Beta } \\
\text { LSC }^{2}\end{array}$ & $\begin{array}{c}\text { Calculation Based } \\
\text { on }{ }^{93} \mathrm{Zr}(\text { See Item } \\
\# 130)\end{array}$ & N/A & $\begin{array}{l}\text { Calculate } \mathrm{Nb}-93 \mathrm{~m} \text { in-growth } \\
\text { based on } \mathrm{Zr}-93 \text { result and age of } \\
\text { waste. For conservatism, use } \\
\text { maximum possible waste age. }\end{array}$ & $X$ & & \\
\hline 102 & ${ }^{59} \mathrm{Ni}$ & $\begin{array}{l}\text { Gamma } \\
\text { GEA }\end{array}$ & LA-508-165 & $\begin{array}{l}\text { DMG separation } \\
\text { using LA-285-102 } \\
\text { Preparation for } \\
\text { gamma counting } \\
\text { per LA-548-121 }\end{array}$ & $\begin{array}{l}\text { SRNL typically uses DMG } \\
\text { separation + LEPS }\end{array}$ & & $X$ & \\
\hline 103 & ${ }^{63} \mathrm{Ni}$ & $\begin{array}{c}\text { Beta } \\
\text { Separate Sample }\end{array}$ & LA-508-121 & $\begin{array}{l}\text { DMG separation } \\
\text { and sample } \\
\text { preparation for } \\
\text { LSC per LA-285- } \\
102\end{array}$ & Concur & $\mathrm{X}$ & & \\
\hline 104 & ${ }^{237} \mathrm{~Np}$ & $\begin{array}{l}\text { Alpha } \\
\text { AEA } \\
\text { ICP-MS }\end{array}$ & $\begin{array}{l}\text { LA-506-102 } \\
\text { LA-508-166 }\end{array}$ & $\begin{array}{l}\text { LA-953-104 } \\
\text { LA-549-141 } \\
\text { LA-549-142 }\end{array}$ & $\begin{array}{l}\text { Ensure digestion is adequate for } \\
\text { Np dissolution (suggest fusion). } \\
\text { LA-953-104 does not contain } \\
\text { sufficient details regarding Np } \\
\text { isolation, applicable } \\
\text { spikes/tracers, and applicable } \\
\text { calculations. }\end{array}$ & $\mathrm{X}$ & & \\
\hline 105 & ${ }^{231} \mathrm{~Pa}$ & $\begin{array}{l}\text { Gamma } \\
\text { GEA }^{3}\end{array}$ & LA-508-165 & LA-548-121 & $\begin{array}{l}\text { Cesium-removal followed by } \\
\text { LEPS. For higher sensitivity, } \\
\text { extract protactinium prior to } \\
\text { LEPS. }\end{array}$ & & & $\mathrm{X}$ \\
\hline
\end{tabular}




\begin{tabular}{|c|c|c|c|c|c|c|c|c|}
\hline \multirow{2}{*}{ Number } & \multirow{2}{*}{$\begin{array}{c}\text { WTP } \\
\text { Processability } \\
\text { Parameter }\end{array}$} & \multirow{2}{*}{$\begin{array}{l}\text { WTP Proposed } \\
\text { Analytical } \\
\text { Methodology }\end{array}$} & \multirow{2}{*}{$\begin{array}{l}\text { WTP Suggested } \\
\text { Analytical } \\
\text { Methods } \\
\text { (Reference Only) }\end{array}$} & \multirow{2}{*}{$\begin{array}{l}\text { WTP Suggested } \\
\text { Sample } \\
\text { Preparations } \\
\text { (Reference Only) }\end{array}$} & \multirow{2}{*}{ SRNL Review Comments ${ }^{1}$} & \multicolumn{3}{|c|}{$\begin{array}{c}\text { SRNL Assessment of WTP } \\
\text { Proposed } \\
\text { Analytical Methodology } \\
\end{array}$} \\
\hline & & & & & & Concur & $\begin{array}{c}\text { Proposed } \\
\text { Alternative }\end{array}$ & $\begin{array}{c}\text { Remains } \\
\text { GAP }\end{array}$ \\
\hline 106 & ${ }^{238} \mathrm{Pu}$ & $\begin{array}{l}\text { Alpha } \\
\text { AEA }\end{array}$ & LA-508-166 & $\begin{array}{l}\text { LA-943-129 } \\
\text { LA-953-104 } \\
\text { LA-549-141 } \\
\text { LA-549-142 }\end{array}$ & $\begin{array}{l}\text { Concur, digestion is important. } \\
\text { Suggest using fusion. }\end{array}$ & $X$ & & \\
\hline 107 & ${ }^{239} \mathrm{Pu}$ & $\begin{array}{l}\text { Alpha } \\
\text { AEA } \\
\text { ICP-MS }\end{array}$ & $\begin{array}{l}\text { LA-506-102 } \\
\text { LA-508-166 }\end{array}$ & $\begin{array}{l}\text { LA-943-129 } \\
\text { LA-953-104 } \\
\text { LA-549-141 } \\
\text { LA-549-142 }\end{array}$ & $\begin{array}{l}\text { Concur, digestion is important. } \\
\text { Suggest using fusion. } \\
\text { AEA biases the Pu- } 239 \text { result } \\
\text { high, since it provides a sum of } \\
\text { the } \mathrm{Pu}-239 \text { and } \mathrm{Pu}-240 \text { activity. } \\
\text { Use ICP-MS to quantify Pu- } 239 \\
\text { by itself. }\end{array}$ & $X$ & & \\
\hline 108 & ${ }^{241} \mathrm{Pu}$ & $\begin{array}{l}\text { Beta } \\
\text { ICP-MS } \\
\text { LSC }\end{array}$ & $\begin{array}{l}\text { LA-506-102 } \\
\text { LA-508-121 }\end{array}$ & $\begin{array}{c}\text { LA-549-141 } \\
\text { LA-549-142 } \\
\text { LA-943-129 } \\
\& \\
\text { LA-548-111 } \\
\end{array}$ & $\begin{array}{l}\text { Concur, digestion is important. } \\
\text { Suggest using fusion. }\end{array}$ & $\mathrm{X}$ & & \\
\hline 109 & ${ }^{242} \mathrm{Pu}$ & $\begin{array}{l}\text { Alpha } \\
\text { AEA }\end{array}$ & LA-508-166 & $\begin{array}{l}\text { LA-549-141 } \\
\text { LA-549-142 } \\
\text { LA-943-129 } \\
\text { LA-953-104 } \\
\end{array}$ & $\begin{array}{l}\text { Concur, digestion is important. } \\
\text { Suggest using fusion. }\end{array}$ & $\mathrm{X}$ & & \\
\hline 110 & ${ }^{226} \mathrm{Ra}$ & $\begin{array}{l}\text { Alpha } \\
\text { AEA }\end{array}$ & LA-508-166 & N/A & $\begin{array}{l}\text { Additional methods may be } \\
\text { required for low level } \\
\text { measurements, SRNL to support } \\
\text { method development activities }\end{array}$ & $X$ & & \\
\hline
\end{tabular}




\begin{tabular}{|c|c|c|c|c|c|c|c|c|}
\hline \multirow{2}{*}{ Number } & \multirow{2}{*}{$\begin{array}{c}\text { WTP } \\
\text { Processability } \\
\text { Parameter }\end{array}$} & \multirow{2}{*}{$\begin{array}{l}\text { WTP Proposed } \\
\text { Analytical } \\
\text { Methodology }\end{array}$} & \multirow{2}{*}{$\begin{array}{l}\text { WTP Suggested } \\
\text { Analytical } \\
\text { Methods } \\
\text { (Reference Only) }\end{array}$} & \multirow{2}{*}{$\begin{array}{l}\text { WTP Suggested } \\
\text { Sample } \\
\text { Preparations } \\
\text { (Reference Only) }\end{array}$} & \multirow{2}{*}{ SRNL Review Comments ${ }^{1}$} & \multicolumn{3}{|c|}{$\begin{array}{c}\text { SRNL Assessment of WTP } \\
\text { Proposed } \\
\text { Analytical Methodology } \\
\end{array}$} \\
\hline & & & & & & Concur & $\begin{array}{c}\text { Proposed } \\
\text { Alternative }\end{array}$ & $\begin{array}{l}\text { Remains } \\
\text { GAP }\end{array}$ \\
\hline 111 & ${ }^{228} \mathrm{Ra}$ & ICP-MS ${ }^{4}$ & LA-506-102 & $\begin{array}{l}\text { LA-549-141 } \\
\text { LA-549-142 }\end{array}$ & $\begin{array}{l}\text { Need to ensure dissolution } \\
\text { (suggest fusion) } \\
\text { is adequate. } \\
\text { May want to consider } \\
\text { calculating Ra-228 based on Th- } \\
\text { 232. This approach is accurate } \\
\text { for long-term inventories ( } \geq 50 \\
\text { years from now). } \\
\text { ICP-MS biases the result high, } \\
\text { since it provides a sum of the } \\
\text { Th-228 and Ra-228 mass. }\end{array}$ & X & & \\
\hline 112 & ${ }^{106} \mathrm{Ru}$ & $\begin{array}{c}\text { Gamma } \\
\text { GEA }\end{array}$ & LA-508-165 & LA- $548-121$ & Concur & $\mathrm{X}$ & & \\
\hline 113 & ${ }^{125} \mathrm{Sb}$ & $\begin{array}{l}\text { Gamma } \\
\text { GEA }\end{array}$ & LA-508-165 & LA-548-121 & Concur & $\mathrm{X}$ & & \\
\hline 114 & ${ }^{79} \mathrm{Se}$ & $\begin{array}{l}\text { Separation and } \\
\text { Beta Counting } \\
\text { LSC } \\
\end{array}$ & LA-508-121 & LA-365-132 & Concur & $\mathrm{X}$ & & \\
\hline
\end{tabular}




\begin{tabular}{|c|c|c|c|c|c|c|c|c|}
\hline \multirow{2}{*}{ Number } & \multirow{2}{*}{$\begin{array}{c}\text { WTP } \\
\text { Processability } \\
\text { Parameter }\end{array}$} & \multirow{2}{*}{$\begin{array}{l}\text { WTP Proposed } \\
\text { Analytical } \\
\text { Methodology }\end{array}$} & \multirow{2}{*}{$\begin{array}{l}\text { WTP Suggested } \\
\text { Analytical } \\
\text { Methods } \\
\text { (Reference Only) }\end{array}$} & \multirow{2}{*}{$\begin{array}{l}\text { WTP Suggested } \\
\text { Sample } \\
\text { Preparations } \\
\text { (Reference Only) }\end{array}$} & \multirow{2}{*}{ SRNL Review Comments ${ }^{1}$} & \multicolumn{3}{|c|}{$\begin{array}{c}\text { SRNL Assessment of WTP } \\
\text { Proposed } \\
\text { Analytical Methodology }\end{array}$} \\
\hline & & & & & & Concur & $\begin{array}{c}\text { Proposed } \\
\text { Alternative }\end{array}$ & $\begin{array}{c}\text { Remains } \\
\text { GAP }\end{array}$ \\
\hline 115 & ${ }^{151} \mathrm{Sm}$ & $\begin{array}{l}\text { Beta } \\
\text { LSC }\end{array}$ & $\begin{array}{l}\text { SRNL Procedure } \\
\text { ADS-2424 }\end{array}$ & $\begin{array}{l}\text { 222-S Procedure } \\
\text { Eichrom LN }\end{array}$ & $\begin{array}{l}\text { SRNL uses CMPO/TBP and } \\
\text { HDEHP extractions to purify } \\
\text { Sm. This is typically necessary } \\
\text { to obtain adequate } \\
\text { decontamination of the } \\
\text { samarium prior to measurement. } \\
\text { If you're depending solely on } \\
\text { extraction by Eichrom LN (in } \\
\text { the absence of a secondary } \\
\text { separation approach such } \\
\text { CMPO/TBP), you may need } \\
\text { multiple cycles of the Eichrom } \\
\text { LN extractions to get sufficient } \\
\text { decontamination. } \\
\text { ADS-2424 only addresses the } \\
\text { beta counting. It does not } \\
\text { address the Sm separation. }\end{array}$ & $\mathrm{X}$ & & \\
\hline 116 & ${ }^{126} \mathrm{Sn}$ & $\begin{array}{l}\text { Gamma } \\
\text { GEA }\end{array}$ & LA-508-165 & LA-548-121 & Concur & $\mathrm{X}$ & & \\
\hline $117 \mathrm{a}$ & ${ }^{121 \mathrm{~m}} \mathrm{Sn}$ & $\begin{array}{l}\text { Beta } \\
\operatorname{LSC}^{5}\end{array}$ & LA-508-121 & $\mathrm{N} / \mathrm{A}$ & $\begin{array}{l}\text { Measure Sn- } 121 \mathrm{~m} \text { by LEPS after } \\
\text { removing cesium. }\end{array}$ & & $\mathrm{X}$ & \\
\hline $117 \mathrm{~b}$ & ${ }^{135} \mathrm{Cs}$ & ICP-MS & LA-506-102 & N/A & $\begin{array}{c}\text { Determine }{ }^{135} \mathrm{Cs} \text { via MS of } \\
\text { extracted cesium and application } \\
\text { of }{ }^{177} \mathrm{Cs} \text { quantity identified by } \\
\text { gamma spec. }\end{array}$ & $\mathrm{X}$ & & \\
\hline 118 & ${ }^{90} \mathrm{Sr}$ & $\begin{array}{l}\text { Beta } \\
\text { LSC }\end{array}$ & LA-508-121 & $\begin{array}{l}\text { LA-220-101 } \\
\quad \& \\
\text { LA-220-106 }\end{array}$ & Concur, likely needs separation. & $\mathrm{X}$ & & \\
\hline
\end{tabular}




\begin{tabular}{|c|c|c|c|c|c|c|c|c|}
\hline \multirow{2}{*}{ Number } & \multirow{2}{*}{$\begin{array}{c}\text { WTP } \\
\text { Processability } \\
\text { Parameter }\end{array}$} & \multirow{2}{*}{$\begin{array}{l}\text { WTP Proposed } \\
\text { Analytical } \\
\text { Methodology }\end{array}$} & \multirow{2}{*}{$\begin{array}{l}\text { WTP Suggested } \\
\text { Analytical } \\
\text { Methods } \\
\text { (Reference Only) }\end{array}$} & \multirow{2}{*}{$\begin{array}{l}\text { WTP Suggested } \\
\text { Sample } \\
\text { Preparations } \\
\text { (Reference Only) }\end{array}$} & \multirow{2}{*}{ SRNL Review Comments ${ }^{1}$} & \multicolumn{3}{|c|}{$\begin{array}{c}\text { SRNL Assessment of WTP } \\
\text { Proposed } \\
\text { Analytical Methodology } \\
\end{array}$} \\
\hline & & & & & & Concur & $\begin{array}{c}\text { Proposed } \\
\text { Alternative }\end{array}$ & $\begin{array}{c}\text { Remains } \\
\text { GAP }\end{array}$ \\
\hline 119 & ${ }^{99} \mathrm{Tc}$ & $\begin{array}{l}\text { Beta } \\
\text { ICP-MS } \\
\text { LSC }\end{array}$ & $\begin{array}{l}\text { LA-506-102 } \\
\text { LA-508-121 }\end{array}$ & $\begin{array}{l}\text { LSC sample } \\
\text { preparation per } \\
\text { LA-438-101 }\end{array}$ & $\begin{array}{l}\text { Concur, may need separation for } \\
\text { beta }\end{array}$ & $\mathrm{X}$ & & \\
\hline 120 & ${ }^{229} \mathrm{Th}$ & $\begin{array}{l}\text { Alpha } \\
\text { ICP-MS }\end{array}$ & $\begin{array}{l}\text { LA-506-102 } \\
\text { LA-508-166 }\end{array}$ & $\begin{array}{l}\text { TEVA Resin } \\
\text { Separation / Co- } \\
\text { precipitation and } \\
\text { Alpha Counting } \\
\text { LA-943-129 } \\
\text { LA-953-104 } \\
\text { LA-549-141 } \\
\text { LA-549-142 }\end{array}$ & $\begin{array}{l}\text { Additional methods may be } \\
\text { required for low level } \\
\text { measurements. } \\
\text { Ensure digestion is adequate for } \\
\text { Th dissolution (suggest fusion). } \\
\text { LA-953-104 addresses Th } \\
\text { purification but it does not } \\
\text { contain sufficient details } \\
\text { regarding Th spikes/tracers and } \\
\text { applicable calculations. LA- } \\
\text { 943-129 does not contain } \\
\text { sufficient details regarding Th } \\
\text { isolation, applicable } \\
\text { spikes/tracers, and applicable } \\
\text { calculations. }\end{array}$ & $\mathrm{X}$ & & \\
\hline 121 & ${ }^{232} \mathrm{Th}$ & $\begin{array}{l}\text { Alpha } \\
\text { AEA } \\
\text { ICP-MS }\end{array}$ & $\begin{array}{l}\text { LA-508-166 } \\
\text { LA-506-102 }\end{array}$ & $\begin{array}{l}\text { LA-943-129 } \\
\text { LA-953-104 }\end{array}$ & $\begin{array}{c}\text { Concur, need to ensure } \\
\text { dissolution (suggest fusion) is } \\
\text { adequate. Typically use ICP- } \\
\text { MS for }{ }^{232} \text { Th. } \\
\text { Same comment as above } \\
\text { regarding the cited procedures. }\end{array}$ & $\mathrm{X}$ & & \\
\hline 122 & TRU & $\begin{array}{l}\text { Alpha or ICP-MS } \\
\text { Results }\end{array}$ & $\begin{array}{c}\text { Calculation Based } \\
\text { on Am, Cm, Np, \& } \\
\text { Pu Isotopes } \\
\text { (See Items \#86, 87, } \\
91,92,104, \& 61)\end{array}$ & N/A & Concur & $\mathrm{X}$ & & \\
\hline
\end{tabular}




\begin{tabular}{|c|c|c|c|c|c|c|c|c|}
\hline \multirow{2}{*}{ Number } & \multirow{2}{*}{$\begin{array}{c}\text { WTP } \\
\text { Processability } \\
\text { Parameter }\end{array}$} & \multirow{2}{*}{$\begin{array}{l}\text { WTP Proposed } \\
\text { Analytical } \\
\text { Methodology }\end{array}$} & \multirow{2}{*}{$\begin{array}{l}\text { WTP Suggested } \\
\text { Analytical } \\
\text { Methods } \\
\text { (Reference Only) }\end{array}$} & \multirow{2}{*}{$\begin{array}{l}\text { WTP Suggested } \\
\text { Sample } \\
\text { Preparations } \\
\text { (Reference Only) }\end{array}$} & \multirow{2}{*}{ SRNL Review Comments ${ }^{1}$} & \multicolumn{3}{|c|}{$\begin{array}{c}\text { SRNL Assessment of WTP } \\
\text { Proposed } \\
\text { Analytical Methodology } \\
\end{array}$} \\
\hline & & & & & & Concur & $\begin{array}{c}\text { Proposed } \\
\text { Alternative }\end{array}$ & $\begin{array}{c}\text { Remains } \\
\text { GAP }\end{array}$ \\
\hline 123 & ${ }^{232} \mathrm{U}$ & $\begin{array}{l}\text { Alpha } \\
\text { AEA } \\
\text { ICP-MS }\end{array}$ & $\begin{array}{l}\text { LA-508-166 } \\
\text { LA-506-102 }\end{array}$ & $\begin{array}{l}\text { LA-943-129 } \\
\text { LA-953-104 } \\
\text { LA-549-141 } \\
\text { LA-549-142 }\end{array}$ & $\begin{array}{l}\text { Concur, need to ensure } \\
\text { dissolution (suggest fusion) and } \\
\text { separations are adequate. } \\
\text { ICP-MS is not recommended, } \\
\text { due to likely extreme dominance } \\
\text { by Th-232, which will bias the } \\
\text { result high. } \\
\text { Neither LA-943-129 nor LA- } \\
\text { 953-104 contains sufficient } \\
\text { details regarding U elution, } \\
\text { applicable spikes/tracers, and } \\
\text { applicable calculations. }\end{array}$ & $\mathrm{X}$ & & \\
\hline 124 & ${ }^{233} \mathrm{U}$ & $\begin{array}{l}\text { Alpha } \\
\text { AEA } \\
\text { ICP-MS }\end{array}$ & $\begin{array}{l}\text { LA-508-166 } \\
\text { LA-506-102 }\end{array}$ & $\begin{array}{l}\text { LA-943-129 } \\
\text { LA-953-104 } \\
\text { LA-549-141 } \\
\text { LA-549-142 }\end{array}$ & $\begin{array}{l}\text { Concur } \\
\text { AEA biases the U-233 result } \\
\text { high, since it provides a sum of } \\
\text { the U-233 and U-234 activity. } \\
\text { Use ICP-MS to quantify U-233 } \\
\text { by itself. } \\
\text { Same comment as above } \\
\text { regarding the cited procedures. }\end{array}$ & $X$ & & \\
\hline 125 & ${ }^{234} \mathrm{U}$ & $\begin{array}{l}\text { Alpha } \\
\text { AEA } \\
\text { ICP-MS }\end{array}$ & $\begin{array}{l}\text { LA-508-166 } \\
\text { LA-506-102 }\end{array}$ & $\begin{array}{l}\text { LA-943-129 } \\
\text { LA-953-104 } \\
\text { LA-549-141 } \\
\text { LA-549-142 }\end{array}$ & $\begin{array}{c}\text { Concur } \\
\text { AEA biases the U-234 result } \\
\text { high, since it provides a sum of } \\
\text { the U-233 and U-234 activity. } \\
\text { Use ICP-MS to quantify U-234 } \\
\text { by itself. } \\
\text { Same comment as above } \\
\text { regarding the cited procedures. }\end{array}$ & $X$ & & \\
\hline
\end{tabular}




\begin{tabular}{|c|c|c|c|c|c|c|c|c|}
\hline \multirow{2}{*}{ Number } & \multirow{2}{*}{$\begin{array}{c}\text { WTP } \\
\text { Processability } \\
\text { Parameter }\end{array}$} & \multirow{2}{*}{$\begin{array}{l}\text { WTP Proposed } \\
\text { Analytical } \\
\text { Methodology }\end{array}$} & \multirow{2}{*}{$\begin{array}{l}\text { WTP Suggested } \\
\text { Analytical } \\
\text { Methods } \\
\text { (Reference Only) }\end{array}$} & \multirow{2}{*}{$\begin{array}{c}\text { WTP Suggested } \\
\text { Sample } \\
\text { Preparations } \\
\text { (Reference Only) }\end{array}$} & \multirow{2}{*}{ SRNL Review Comments ${ }^{1}$} & \multicolumn{3}{|c|}{$\begin{array}{c}\text { SRNL Assessment of WTP } \\
\text { Proposed } \\
\text { Analytical Methodology }\end{array}$} \\
\hline & & & & & & Concur & $\begin{array}{c}\text { Proposed } \\
\text { Alternative }\end{array}$ & $\begin{array}{c}\text { Remains } \\
\text { GAP }\end{array}$ \\
\hline 126 & ${ }^{235} \mathrm{U}$ & $\begin{array}{l}\text { Alpha } \\
\text { AEA } \\
\text { ICP-MS }\end{array}$ & $\begin{array}{l}\text { LA-508-166 } \\
\text { LA-506-102 }\end{array}$ & $\begin{array}{l}\text { LA-943-129 } \\
\text { LA-953-104 } \\
\text { LA-549-141 } \\
\text { LA-549-142 }\end{array}$ & $\begin{array}{l}\text { Concur } \\
\text { AEA biases the U-235 result } \\
\text { high, since it provides a sum of } \\
\text { the U- } 235 \text { and U- } 236 \text { activity. } \\
\text { Use ICP-MS to quantify U-235 } \\
\text { by itself. } \\
\text { Same comment as above } \\
\text { regarding the cited procedures. }\end{array}$ & $X$ & & \\
\hline 127 & ${ }^{236} \mathrm{U}$ & $\begin{array}{l}\text { Alpha } \\
\text { AEA } \\
\text { ICP-MS }\end{array}$ & $\begin{array}{l}\text { LA-508-166 } \\
\text { LA-506-102 }\end{array}$ & $\begin{array}{l}\text { LA-943-129 } \\
\text { LA-953-104 } \\
\text { LA-549-141 } \\
\text { LA-549-142 }\end{array}$ & $\begin{array}{l}\text { Concur } \\
\text { AEA biases the U-236 result } \\
\text { high, since it provides a sum of } \\
\text { the U- } 235 \text { and U-236 activity. } \\
\text { Use ICP-MS to quantify U-236 } \\
\text { by itself. } \\
\text { Same comment as above } \\
\text { regarding the cited procedures. }\end{array}$ & $X$ & & \\
\hline 128 & ${ }^{238} \mathrm{U}$ & $\begin{array}{l}\text { Alpha } \\
\text { AEA } \\
\text { ICP-MS }\end{array}$ & $\begin{array}{l}\text { LA-508-166 } \\
\text { LA-506-102 }\end{array}$ & $\begin{array}{l}\text { LA-943-129 } \\
\text { LA-953-104 } \\
\text { LA-549-141 } \\
\text { LA-549-142 } \\
\end{array}$ & $\begin{array}{l}\text { Concur } \\
\text { Same comment as above } \\
\text { regarding the cited procedures. }\end{array}$ & $\mathrm{X}$ & & \\
\hline 129 & ${ }^{90} \mathrm{Y}$ & $\begin{array}{l}\text { Calculation } \\
\text { Based } \\
\text { on }{ }^{90} \mathrm{Sr} \text { Result } \\
\text { (See Item \#118) } \\
\end{array}$ & N/A & N/A & Concur & $\mathrm{X}$ & & \\
\hline
\end{tabular}




\begin{tabular}{|c|c|c|c|c|c|c|c|c|}
\hline \multirow{2}{*}{ Number } & \multirow{2}{*}{$\begin{array}{c}\text { WTP } \\
\text { Processability } \\
\text { Parameter }\end{array}$} & \multirow{2}{*}{$\begin{array}{l}\text { WTP Proposed } \\
\text { Analytical } \\
\text { Methodology }{ }^{1}\end{array}$} & \multirow{2}{*}{$\begin{array}{l}\text { WTP Suggested } \\
\text { Analytical } \\
\text { Methods } \\
\text { (Reference Only) }\end{array}$} & \multirow{2}{*}{$\begin{array}{l}\text { WTP Suggested } \\
\text { Sample } \\
\text { Preparations } \\
\text { (Reference Only) }\end{array}$} & \multirow{2}{*}{ SRNL Review Comments ${ }^{1}$} & \multicolumn{3}{|c|}{$\begin{array}{c}\text { SRNL Assessment of WTP } \\
\text { Proposed } \\
\text { Analytical Methodology } \\
\end{array}$} \\
\hline & & & & & & Concur & $\begin{array}{c}\text { Proposed } \\
\text { Alternative }\end{array}$ & $\begin{array}{c}\text { Remains } \\
\text { GAP }\end{array}$ \\
\hline 130 & ${ }^{93} \mathrm{Zr}$ & $\begin{array}{c}\text { Beta } \\
\text { ICP-MS } \\
\text { LSC Counting }\end{array}$ & LA-506-102 & $\begin{array}{l}\text { Chemical } \\
\text { Separation } \\
\text { Required }\end{array}$ & $\begin{array}{l}\text { Use MS for Waste Acceptance } \\
\text { Product Specifications samples } \\
\text { and this give supper bound. Use } \\
\text { separations for Tank Closure to } \\
\text { get lower detection limit. SRNL } \\
\text { provided methodology for } \\
\text { separation (CMPO and tributyl } \\
\text { phosphate for separation } \\
\text { followed by ICP-MS). }\end{array}$ & $\mathrm{X}$ & & \\
\hline 130.1 & ${ }^{95} \mathrm{Zr}$ & $\begin{array}{l}\text { Gamma } \\
\text { GEA }\end{array}$ & LA-508-165 & LA- $548-121$ & $\begin{array}{l}\text { Due to the short half-life of }{ }^{95} \mathrm{Zr} \text {, } \\
\text { SRNL only analyzes }{ }^{95} \mathrm{Zr} \text { in fresh } \\
\text { waste samples, not in Tank Farm } \\
\text { samples. }\end{array}$ & $\mathrm{X}$ & & \\
\hline
\end{tabular}

${ }^{1}$ Note:

AEA: alpha energy analysis

CMPO: carbamoylmethylphosphine oxide

DMG: dimethylgloyoxime

DQO: data quality objective

GEA: gamma energy analysis

HDEHP: bis-(2-ethylhexyl) phosphoric acid

IC: ion chromatography

ICP-MS: inductively coupled plasma - mass spectroscopy

LEPS: low energy photon spectroscopy

LSC: liquid scintillation counting

N/A: not applicable

TBP: tribuyl phosphate

TEVA: tetravalent actinide

SRNL: Savannah River National Laboratory

WAC: waste acceptance criteria

WTP: Hanford Tank Waste Treatment and Immobilization Plant 
SRNL-STI-2011-00724

Revision 0

${ }^{2}$ Note: This trace radionuclide can be scaled from ${ }^{93} \mathrm{Zr}$; WTP does not plan to measure/analyze; will perform calculation

${ }^{3}$ Note: Contribution insignificant; will use predictable list or scaling factor from ${ }^{235} \mathrm{U}$ decay

${ }^{4}$ Note: Need to address minimum detectable activity (MDA) if ICP-MS is used.

${ }^{5}$ Note: Need to address minimum detectable activity (MDA) for LSC counting. 
Table A-4. Review of WAC-DQO “Organics” Worksheet

\begin{tabular}{|c|c|c|c|c|c|c|c|c|}
\hline \multirow{2}{*}{ Number } & \multirow{2}{*}{$\begin{array}{l}\text { WTP Processability } \\
\text { Parameter }\end{array}$} & \multirow{2}{*}{$\begin{array}{l}\text { WTP Proposed } \\
\text { Analytical } \\
\text { Methodology }\end{array}$} & \multirow{2}{*}{$\begin{array}{l}\text { WTP Suggested } \\
\text { Analytical } \\
\text { Methods } \\
\text { (Reference Only) }\end{array}$} & \multirow{2}{*}{$\begin{array}{c}\text { WTP Suggested } \\
\text { Sample } \\
\text { Preparations } \\
\text { (Reference Only) }\end{array}$} & \multirow{2}{*}{ SRNL Review Comments ${ }^{1}$} & \multicolumn{3}{|c|}{$\begin{array}{c}\text { SRNL Assessment of WTP } \\
\text { Proposed } \\
\text { Analytical Methodology }\end{array}$} \\
\hline & & & & & & Concur & $\begin{array}{c}\text { Proposed } \\
\text { Alternative }\end{array}$ & $\begin{array}{c}\text { Remains } \\
\text { GAP }\end{array}$ \\
\hline 131 & p-Nitrochlorobenzene & $\begin{array}{l}\text { SVOA } \\
\text { GC-MS }\end{array}$ & $\begin{array}{c}\text { EPA } 8270 \\
\text { LA-523-135 }\end{array}$ & $\begin{array}{l}\text { LA-523-115 } \\
\text { LA-523-138 } \\
\text { LA-523-141 } \\
\text { LA-523-144 } \\
\text { LA-523-145 }\end{array}$ & & $\mathrm{X}$ & & \\
\hline 132 & 1,4-Dinitrobenzene & $\begin{array}{l}\text { SVOA } \\
\text { GC-MS }\end{array}$ & $\begin{array}{c}\text { EPA } 8270 \\
\text { LA-523-135 }\end{array}$ & $\begin{array}{l}\text { LA-523-115 } \\
\text { LA-523-138 } \\
\text { LA-523-141 } \\
\text { LA-523-144 } \\
\text { LA-523-145 }\end{array}$ & & $\mathrm{X}$ & & \\
\hline 133 & 1,4-Dichlorobenzene & $\begin{array}{c}\text { SVOA/VOA } \\
\text { GC-MS }\end{array}$ & $\begin{array}{l}\text { EPA } 8260 / 8270 \\
\text { LA-523-135 } \\
\text { LA-523-118 }\end{array}$ & $\begin{array}{l}\text { LA-523-115 } \\
\text { LA-523-138 } \\
\text { LA-523-141 } \\
\text { LA-523-144 } \\
\text { LA-523-145 }\end{array}$ & & $X$ & & \\
\hline 134 & Phenol & $\begin{array}{l}\text { SVOA } \\
\text { GC-MS }\end{array}$ & $\begin{array}{c}\text { EPA } 8270 \\
\text { LA-523-135 }\end{array}$ & $\begin{array}{l}\text { LA-523-115 } \\
\text { LA-523-138 } \\
\text { LA-523-141 } \\
\text { LA-523-144 } \\
\text { LA-523-145 }\end{array}$ & & $X$ & & \\
\hline 135 & Pyridine & $\begin{array}{l}\text { SVOA/VOA } \\
\text { GC-MS }\end{array}$ & $\begin{array}{l}\text { EPA } 8260 / 8270 \\
\text { LA-523-135 } \\
\text { LA-523-118 }\end{array}$ & $\begin{array}{l}\text { LA-523-115 } \\
\text { LA-523-138 } \\
\text { LA-523-141 } \\
\text { LA-523-144 } \\
\text { LA-523-145 }\end{array}$ & $\begin{array}{c}\text { EPA } 8015,8260,8261, \\
\text { proposed alternative EPA } \\
8260 \text { only }\end{array}$ & & $X$ & \\
\hline 136 & $\begin{array}{c}1,2,4- \\
\text { Trichlorobenzene }\end{array}$ & $\begin{array}{l}\text { SVOA/VOA } \\
\text { GC-MS }\end{array}$ & $\begin{array}{l}\text { EPA } 8260 / 8270 \\
\text { LA-523-135 } \\
\text { LA-523-118 }\end{array}$ & $\begin{array}{l}\text { LA-523-115 } \\
\text { LA-523-138 } \\
\text { LA-523-141 } \\
\text { LA-523-144 } \\
\text { LA-523-145 }\end{array}$ & & $\mathrm{X}$ & & \\
\hline
\end{tabular}




\begin{tabular}{|c|c|c|c|c|c|c|c|c|}
\hline \multirow{2}{*}{ Number } & \multirow{2}{*}{$\begin{array}{l}\text { WTP Processability } \\
\text { Parameter }\end{array}$} & \multirow{2}{*}{$\begin{array}{l}\text { WTP Proposed } \\
\text { Analytical } \\
\text { Methodology }\end{array}$} & \multirow{2}{*}{$\begin{array}{l}\text { WTP Suggested } \\
\text { Analytical } \\
\text { Methods } \\
\text { (Reference Only) }\end{array}$} & \multirow{2}{*}{$\begin{array}{l}\text { WTP Suggested } \\
\text { Sample } \\
\text { Preparations } \\
\text { (Reference Only) }\end{array}$} & \multirow{2}{*}{ SRNL Review Comments ${ }^{1}$} & \multicolumn{3}{|c|}{$\begin{array}{c}\text { SRNL Assessment of WTP } \\
\text { Proposed } \\
\text { Analytical Methodology } \\
\end{array}$} \\
\hline & & & & & & Concur & $\begin{array}{c}\text { Proposed } \\
\text { Alternative }\end{array}$ & $\begin{array}{l}\text { Remains } \\
\text { GAP }\end{array}$ \\
\hline 137 & 2,4-Dichlorophenol & $\begin{array}{c}\text { SVOA } \\
\text { GC-MS }\end{array}$ & $\begin{array}{c}\text { EPA 8270 } \\
\text { LA-523-135 }\end{array}$ & $\begin{array}{l}\text { LA-523-115 } \\
\text { LA-523-138 } \\
\text { LA-523-141 } \\
\text { LA-523-144 } \\
\text { LA-523-145 }\end{array}$ & & $\mathrm{X}$ & & \\
\hline 138 & N,N-Diphenylamine & $\begin{array}{c}\text { SVOA } \\
\text { GC-MS }\end{array}$ & $\begin{array}{c}\text { EPA 8270 } \\
\text { LA-523-135 }\end{array}$ & $\begin{array}{l}\text { LA-523-115 } \\
\text { LA-523-138 } \\
\text { LA-523-141 } \\
\text { LA-523-144 } \\
\text { LA-523-145 }\end{array}$ & & $\mathrm{X}$ & & \\
\hline 139 & Tributyl phosphate & $\begin{array}{c}\text { SVOA } \\
\text { GC-MS }\end{array}$ & $\begin{array}{c}\text { EPA } 8270 \\
\text { LA-523-135 }\end{array}$ & $\begin{array}{l}\text { LA-523-115 } \\
\text { LA-523-138 } \\
\text { LA-523-141 } \\
\text { LA-523-144 } \\
\text { LA-523-145 } \\
\end{array}$ & & $\mathrm{X}$ & & \\
\hline 140 & $\begin{array}{l}\text { 2,6-Bis(tert-butyl)-4- } \\
\text { methylphenol }\end{array}$ & $\begin{array}{c}\text { SVOA } \\
\text { GC-MS }\end{array}$ & $\begin{array}{l}\text { EPA } 8270 \\
\text { LA-523-135 }\end{array}$ & $\begin{array}{l}\text { LA-523-115 } \\
\text { LA-523-138 } \\
\text { LA-523-141 } \\
\text { LA-523-144 } \\
\text { LA-523-145 }\end{array}$ & & $\mathrm{X}$ & & \\
\hline 141 & Benzo(a)pyrene & $\begin{array}{c}\text { SVOA } \\
\text { GC-MS }\end{array}$ & $\begin{array}{l}\text { EPA } 8270 \\
\text { LA-523-135 }\end{array}$ & $\begin{array}{l}\text { LA-523-115 } \\
\text { LA-523-138 } \\
\text { LA-523-141 } \\
\text { LA-523-144 } \\
\text { LA-523-145 } \\
\end{array}$ & & $\mathrm{X}$ & & \\
\hline 142 & $\begin{array}{c}\operatorname{Dibenz}[\mathrm{a}, \mathrm{h}] \mathrm{anthracen} \\
\mathrm{e}\end{array}$ & $\begin{array}{l}\text { SVOA } \\
\text { GC-MS }\end{array}$ & $\begin{array}{l}\text { EPA } 8270 \\
\text { LA-523-135 }\end{array}$ & $\begin{array}{l}\text { LA-523-115 } \\
\text { LA-523-138 } \\
\text { LA-523-141 } \\
\text { LA-523-144 } \\
\text { LA-523-145 }\end{array}$ & & $\mathrm{X}$ & & \\
\hline
\end{tabular}




\begin{tabular}{|c|c|c|c|c|c|c|c|c|}
\hline \multirow{2}{*}{ Number } & \multirow{2}{*}{$\begin{array}{l}\text { WTP Processability } \\
\text { Parameter }\end{array}$} & \multirow{2}{*}{$\begin{array}{c}\text { WTP Proposed } \\
\text { Analytical } \\
\text { Methodology }\end{array}$} & \multirow{2}{*}{$\begin{array}{l}\text { WTP Suggested } \\
\text { Analytical } \\
\text { Methods } \\
\text { (Reference Only) }\end{array}$} & \multirow{2}{*}{$\begin{array}{l}\text { WTP Suggested } \\
\text { Sample } \\
\text { Preparations } \\
\text { (Reference Only) }\end{array}$} & \multirow{2}{*}{ SRNL Review Comments ${ }^{1}$} & \multicolumn{3}{|c|}{$\begin{array}{c}\text { SRNL Assessment of WTP } \\
\text { Proposed } \\
\text { Analytical Methodology } \\
\end{array}$} \\
\hline & & & & & & Concur & $\begin{array}{l}\text { Proposed } \\
\text { Alternative }\end{array}$ & $\begin{array}{l}\text { Remains } \\
\text { GAP }\end{array}$ \\
\hline 143 & 1,3-Dichlorobenzene & $\begin{array}{l}\text { SVOA/VOA } \\
\text { GC-MS }\end{array}$ & $\begin{array}{l}\text { EPA } 8260 / 8270 \\
\text { LA-523-135 } \\
\text { LA-523-118 }\end{array}$ & $\begin{array}{l}\text { LA-523-115 } \\
\text { LA-523-138 } \\
\text { LA-523-141 } \\
\text { LA-523-144 } \\
\text { LA-523-145 }\end{array}$ & & $X$ & & \\
\hline 144 & $\begin{array}{l}\text { 4-Chloro-3- } \\
\text { methylphenol }\end{array}$ & $\begin{array}{c}\text { SVOA } \\
\text { GC-MS }\end{array}$ & $\begin{array}{l}\text { EPA } 8270 \\
\text { LA-523-135 }\end{array}$ & $\begin{array}{l}\text { LA-523-115 } \\
\text { LA-523-138 } \\
\text { LA-523-141 } \\
\text { LA-523-144 } \\
\text { LA-523-145 } \\
\end{array}$ & & $X$ & & \\
\hline 145 & $\begin{array}{l}\text { Nitric acid, propyl } \\
\text { ester } \\
\text { (n-propyl nitrate) }\end{array}$ & $\begin{array}{l}\text { SVOA/VOA } \\
\text { GC-MS }\end{array}$ & $\begin{array}{l}\text { EPA } 8260 / 8270 \\
\text { LA-523-135 } \\
\text { LA-523-118 }\end{array}$ & $\begin{array}{l}\text { LA-523-115 } \\
\text { LA-523-138 } \\
\text { LA-523-141 } \\
\text { LA-523-144 } \\
\text { LA-523-145 }\end{array}$ & $\begin{array}{l}\text { CAS No. 627-13-4 } \\
\text { (corrected), Hanford } \\
\text { experience with running this } \\
\text { analysis }\end{array}$ & $\mathrm{X}$ & & \\
\hline 146 & $\begin{array}{l}\text { N-Nitroso-N,N- } \\
\text { dimethylamine }\end{array}$ & $\begin{array}{c}\text { SVOA } \\
\text { GC-MS }\end{array}$ & $\begin{array}{l}\text { EPA } 8270 \\
\text { LA-523-135 }\end{array}$ & $\begin{array}{l}\text { LA-523-115 } \\
\text { LA-523-138 } \\
\text { LA-523-141 } \\
\text { LA-523-144 } \\
\text { LA-523-145 }\end{array}$ & thermally labile & $\mathrm{X}$ & & \\
\hline 147 & Hexachloroethane & $\begin{array}{c}\text { SVOA } \\
\text { GC-MS }\end{array}$ & $\begin{array}{l}\text { EPA } 8270 \\
\text { LA-523-135 }\end{array}$ & $\begin{array}{l}\text { LA-523-115 } \\
\text { LA-523-138 } \\
\text { LA-523-141 } \\
\text { LA-523-144 } \\
\text { LA-523-145 } \\
\end{array}$ & & $\mathrm{X}$ & & \\
\hline 148 & $\begin{array}{l}\text { Pentachloronitrobenz } \\
\text { ene (PCNB) }\end{array}$ & $\begin{array}{l}\text { SVOA } \\
\text { GC-MS }\end{array}$ & $\begin{array}{l}\text { EPA } 8270 \\
\text { LA-523-135 }\end{array}$ & $\begin{array}{l}\text { LA-523-115 } \\
\text { LA-523-138 } \\
\text { LA-523-141 } \\
\text { LA-523-144 } \\
\text { LA-523-145 } \\
\end{array}$ & & $\mathrm{X}$ & & \\
\hline
\end{tabular}




\begin{tabular}{|c|c|c|c|c|c|c|c|c|}
\hline \multirow{2}{*}{ Number } & \multirow{2}{*}{$\begin{array}{l}\text { WTP Processability } \\
\text { Parameter }\end{array}$} & \multirow{2}{*}{$\begin{array}{l}\text { WTP Proposed } \\
\text { Analytical } \\
\text { Methodology }\end{array}$} & \multirow{2}{*}{$\begin{array}{l}\text { WTP Suggested } \\
\text { Analytical } \\
\text { Methods } \\
\text { (Reference Only) }\end{array}$} & \multirow{2}{*}{$\begin{array}{l}\text { WTP Suggested } \\
\text { Sample } \\
\text { Preparations } \\
\text { (Reference Only) }\end{array}$} & \multirow{2}{*}{ SRNL Review Comments ${ }^{1}$} & \multicolumn{3}{|c|}{$\begin{array}{c}\text { SRNL Assessment of WTP } \\
\text { Proposed } \\
\text { Analytical Methodology } \\
\end{array}$} \\
\hline & & & & & & Concur & $\begin{array}{c}\text { Proposed } \\
\text { Alternative }\end{array}$ & $\begin{array}{c}\text { Remains } \\
\text { GAP }\end{array}$ \\
\hline 149 & Hexachlorobutadiene & $\begin{array}{l}\text { SVOA/VOA } \\
\text { GC-MS }\end{array}$ & $\begin{array}{l}\text { EPA } 8260 / 8270 \\
\text { LA-523-135 } \\
\text { LA-523-118 }\end{array}$ & $\begin{array}{l}\text { LA-523-115 } \\
\text { LA-523-138 } \\
\text { LA-523-141 } \\
\text { LA-523-144 } \\
\text { LA-523-145 }\end{array}$ & & $\mathrm{X}$ & & \\
\hline 150 & Pentachlorophenol & $\begin{array}{l}\text { SVOA } \\
\text { GC-MS }\end{array}$ & $\begin{array}{l}\text { EPA } 8270 \\
\text { LA-523-135 }\end{array}$ & $\begin{array}{l}\text { LA-523-115 } \\
\text { LA-523-138 } \\
\text { LA-523-141 } \\
\text { LA-523-144 } \\
\text { LA-523-145 }\end{array}$ & & $\mathrm{X}$ & & \\
\hline 151 & $\begin{array}{l}\text { 2-sec-Butyl-4,6- } \\
\text { dinitrophenol } \\
\text { (Dinoseb) }\end{array}$ & $\begin{array}{l}\text { SVOA } \\
\text { GC-MS }\end{array}$ & $\begin{array}{l}\text { EPA } 8270 \\
\text { LA-523-135 }\end{array}$ & $\begin{array}{l}\text { LA-523-115 } \\
\text { LA-523-138 } \\
\text { LA-523-141 } \\
\text { LA-523-144 } \\
\text { LA-523-145 }\end{array}$ & & $\mathrm{X}$ & & \\
\hline 152 & 1,1’-Biphenyl & $\begin{array}{l}\text { SVOA } \\
\text { GC-MS }\end{array}$ & $\begin{array}{c}\text { EPA 8270 } \\
\text { LA-523-135 }\end{array}$ & $\begin{array}{l}\text { LA-523-115 } \\
\text { LA-523-138 } \\
\text { LA-523-141 } \\
\text { LA-523-144 } \\
\text { LA-523-145 }\end{array}$ & & $\mathrm{X}$ & & \\
\hline 153 & 1,2-Dichlorobenzene & $\begin{array}{l}\text { SVOA/VOA } \\
\text { GC-MS }\end{array}$ & $\begin{array}{l}\text { EPA } 8260 / 8270 \\
\text { LA-523-135 } \\
\text { LA-523-118 }\end{array}$ & $\begin{array}{l}\text { LA-523-115 } \\
\text { LA-523-138 } \\
\text { LA-523-141 } \\
\text { LA-523-144 } \\
\text { LA-523-145 }\end{array}$ & & $\mathrm{X}$ & & \\
\hline 154 & Acetophenone & $\begin{array}{l}\text { SVOA } \\
\text { GC-MS }\end{array}$ & $\begin{array}{l}\text { EPA } 8270 \\
\text { LA-523-135 }\end{array}$ & $\begin{array}{l}\text { LA-523-115 } \\
\text { LA-523-138 } \\
\text { LA-523-141 } \\
\text { LA-523-144 } \\
\text { LA-523-145 }\end{array}$ & & $\mathrm{X}$ & & \\
\hline
\end{tabular}




\begin{tabular}{|c|c|c|c|c|c|c|c|c|}
\hline \multirow{2}{*}{ Number } & \multirow{2}{*}{$\begin{array}{l}\text { WTP Processability } \\
\text { Parameter }\end{array}$} & \multirow{2}{*}{$\begin{array}{l}\text { WTP Proposed } \\
\text { Analytical } \\
\text { Methodology }\end{array}$} & \multirow{2}{*}{$\begin{array}{l}\text { WTP Suggested } \\
\text { Analytical } \\
\text { Methods } \\
\text { (Reference Only) }\end{array}$} & \multirow{2}{*}{$\begin{array}{l}\text { WTP Suggested } \\
\text { Sample } \\
\text { Preparations } \\
\text { (Reference Only) }\end{array}$} & \multirow{2}{*}{ SRNL Review Comments ${ }^{1}$} & \multicolumn{3}{|c|}{$\begin{array}{c}\text { SRNL Assessment of WTP } \\
\text { Proposed } \\
\text { Analytical Methodology } \\
\end{array}$} \\
\hline & & & & & & Concur & $\begin{array}{c}\text { Proposed } \\
\text { Alternative }\end{array}$ & $\begin{array}{l}\text { Remains } \\
\text { GAP }\end{array}$ \\
\hline 155 & Nitrobenzene & $\begin{array}{l}\text { SVOA } \\
\text { GC-MS }\end{array}$ & $\begin{array}{l}\text { EPA } 8270 \\
\text { LA-523-135 }\end{array}$ & $\begin{array}{l}\text { LA-523-115 } \\
\text { LA-523-138 } \\
\text { LA-523-141 } \\
\text { LA-523-144 } \\
\text { LA-523-145 }\end{array}$ & & $\mathrm{X}$ & & \\
\hline 156 & Ethyl benzene & $\begin{array}{l}\text { VOA } \\
\text { GC-MS }\end{array}$ & $\begin{array}{l}\text { EPA } 8260 \\
\text { LA-523-118 }\end{array}$ & N/A & & $\mathrm{X}$ & & \\
\hline 157 & Styrene & $\begin{array}{l}\text { VOA } \\
\text { GC-MS }\end{array}$ & $\begin{array}{c}\text { EPA } 8260 \\
\text { LA-523-118 }\end{array}$ & N/A & & $\mathrm{X}$ & & \\
\hline 158 & $\begin{array}{c}\text { cis-1,3- } \\
\text { Dichloropropene }\end{array}$ & $\begin{array}{l}\text { VOA } \\
\text { GC-MS }\end{array}$ & $\begin{array}{c}\text { EPA } 8260 \\
\text { LA-523-118 }\end{array}$ & N/A & & $\mathrm{X}$ & & \\
\hline 159 & $\begin{array}{c}\text { trans-1,3- } \\
\text { Dichloropropene }\end{array}$ & $\begin{array}{l}\text { VOA } \\
\text { GC-MS }\end{array}$ & $\begin{array}{l}\text { EPA } 8260 \\
\text { LA-523-118 }\end{array}$ & N/A & & $\mathrm{X}$ & & \\
\hline 160 & 3-Heptanone & $\begin{array}{l}\text { VOA } \\
\text { GC-MS }\end{array}$ & $\begin{array}{l}\text { EPA } 8260^{2} \\
\text { LA-523-118 }\end{array}$ & N/A & $\begin{array}{c}\text { proposed alternative EPA } \\
8315 \text { HPLC }\end{array}$ & & $\mathrm{X}$ & \\
\hline 161 & $\begin{array}{c}\text { p-Xylene \& m- } \\
\text { Xylene }\end{array}$ & $\begin{array}{l}\text { VOA } \\
\text { GC-MS }\end{array}$ & $\begin{array}{c}\text { EPA } 8260 \\
\text { LA-523-118 }\end{array}$ & N/A & & $\mathrm{X}$ & & \\
\hline 162 & Ethylene dibromide & $\begin{array}{l}\text { VOA } \\
\text { GC-MS }\end{array}$ & $\begin{array}{l}\text { EPA } 8260 \\
\text { LA-523-118 }\end{array}$ & N/A & & $\mathrm{X}$ & & \\
\hline 163 & Butane & $\begin{array}{l}\text { VOA } \\
\text { GC-MS }\end{array}$ & $\begin{array}{l}\text { EPA } 8260^{2} \\
\text { LA-523-118 }\end{array}$ & N/A & & $\mathrm{X}$ & & \\
\hline 164 & 1,3-Butadiene & $\begin{array}{l}\text { VOA } \\
\text { GC-MS }\end{array}$ & $\begin{array}{l}\text { EPA } 8260^{2} \\
\text { LA-523-118 }\end{array}$ & N/A & & $\mathrm{X}$ & & \\
\hline 165 & Acrolein & $\begin{array}{l}\text { VOA } \\
\text { GC-MS }\end{array}$ & $\begin{array}{l}\text { EPA } 8260 \\
\text { LA-523-118 }\end{array}$ & N/A & & $\mathrm{X}$ & & \\
\hline
\end{tabular}




\begin{tabular}{|c|c|c|c|c|c|c|c|c|}
\hline \multirow{2}{*}{ Number } & \multirow{2}{*}{$\begin{array}{l}\text { WTP Processability } \\
\text { Parameter }\end{array}$} & \multirow{2}{*}{$\begin{array}{l}\text { WTP Proposed } \\
\text { Analytical } \\
\text { Methodology }\end{array}$} & \multirow{2}{*}{$\begin{array}{l}\text { WTP Suggested } \\
\text { Analytical } \\
\text { Methods } \\
\text { (Reference Only) }\end{array}$} & \multirow{2}{*}{$\begin{array}{c}\text { WTP Suggested } \\
\text { Sample } \\
\text { Preparations } \\
\text { (Reference Only) }\end{array}$} & \multirow{2}{*}{ SRNL Review Comments ${ }^{1}$} & \multicolumn{3}{|c|}{$\begin{array}{c}\text { SRNL Assessment of WTP } \\
\text { Proposed } \\
\text { Analytical Methodology } \\
\end{array}$} \\
\hline & & & & & & Concur & $\begin{array}{c}\text { Proposed } \\
\text { Alternative }\end{array}$ & $\begin{array}{c}\text { Remains } \\
\text { GAP }\end{array}$ \\
\hline 166 & 3-Chloropropene & $\begin{array}{c}\text { VOA } \\
\text { GC-MS }\end{array}$ & $\begin{array}{l}\text { EPA } 8260^{2} \\
\text { LA-523-118 }\end{array}$ & N/A & & $X$ & & \\
\hline 167 & 1,2-Dichloroethane & $\begin{array}{c}\text { VOA } \\
\text { GC-MS }\end{array}$ & $\begin{array}{c}\text { EPA } 8260 \\
\text { LA-523-118 }\end{array}$ & N/A & & $\mathrm{X}$ & & \\
\hline 168 & Propionitrile & $\begin{array}{l}\text { VOA } \\
\text { GC-MS }\end{array}$ & $\begin{array}{c}\text { EPA } 8260 \\
\text { LA-523-118 }\end{array}$ & N/A & ethyl cyanide & $\mathrm{X}$ & & \\
\hline 169 & Acrylonitrile & $\begin{array}{l}\text { VOA } \\
\text { GC-MS }\end{array}$ & $\begin{array}{c}\text { EPA } 8260 \\
\text { LA-523-118 }\end{array}$ & N/A & & $\mathrm{X}$ & & \\
\hline 170 & 2-Pentanone & $\begin{array}{c}\text { VOA } \\
\text { GC-MS }\end{array}$ & $\begin{array}{c}\text { EPA } 8260 \\
\text { LA-523-118 }\end{array}$ & N/A & & $X$ & & \\
\hline 171 & $\begin{array}{l}\text { 4-Methyl-2- } \\
\text { pentanone }\end{array}$ & $\begin{array}{c}\text { VOA } \\
\text { GC-MS }\end{array}$ & $\begin{array}{c}\text { EPA } 8260 \\
\text { LA-523-118 }\end{array}$ & N/A & & $X$ & & \\
\hline 172 & m-Xylene & $\begin{array}{l}\text { VOA } \\
\text { GC-MS }\end{array}$ & $\begin{array}{c}\text { EPA } 8260 \\
\text { LA-523-118 }\end{array}$ & N/A & & $\mathrm{X}$ & & \\
\hline 173 & Methylcyclohexane & $\begin{array}{l}\text { VOA } \\
\text { GC-MS }\end{array}$ & $\begin{array}{l}\text { EPA } 8260^{2} \\
\text { LA-523-118 }\end{array}$ & N/A & & $\mathrm{X}$ & & \\
\hline 174 & Toluene & $\begin{array}{c}\text { VOA } \\
\text { GC-MS }\end{array}$ & $\begin{array}{c}\text { EPA } 8260 \\
\text { LA-523-118 }\end{array}$ & $\mathrm{N} / \mathrm{A}$ & & $X$ & & \\
\hline 175 & Chlorobenzene & $\begin{array}{c}\text { VOA } \\
\text { GC-MS }\end{array}$ & $\begin{array}{c}\text { EPA } 8260 \\
\text { LA-523-118 }\end{array}$ & N/A & & $\mathrm{X}$ & & \\
\hline 176 & Cyclohexanone & $\begin{array}{c}\text { VOA } \\
\text { GC-MS }\end{array}$ & $\begin{array}{l}\text { EPA } 8260^{2} \\
\text { LA-523-118 }\end{array}$ & N/A & $\begin{array}{c}\text { proposed alternative EPA } \\
8315 \text { HPLC }\end{array}$ & & $\mathrm{X}$ & \\
\hline
\end{tabular}




\begin{tabular}{|c|c|c|c|c|c|c|c|c|}
\hline \multirow{2}{*}{ Number } & \multirow{2}{*}{$\begin{array}{l}\text { WTP Processability } \\
\text { Parameter }\end{array}$} & \multirow{2}{*}{$\begin{array}{l}\text { WTP Proposed } \\
\text { Analytical } \\
\text { Methodology }\end{array}$} & \multirow{2}{*}{$\begin{array}{l}\text { WTP Suggested } \\
\text { Analytical } \\
\text { Methods } \\
\text { (Reference Only) }\end{array}$} & \multirow{2}{*}{$\begin{array}{l}\text { WTP Suggested } \\
\text { Sample } \\
\text { Preparations } \\
\text { (Reference Only) }\end{array}$} & \multirow{2}{*}{ SRNL Review Comments ${ }^{1}$} & \multicolumn{3}{|c|}{$\begin{array}{c}\text { SRNL Assessment of WTP } \\
\text { Proposed } \\
\text { Analytical Methodology }\end{array}$} \\
\hline & & & & & & Concur & $\begin{array}{c}\text { Proposed } \\
\text { Alternative }\end{array}$ & $\begin{array}{l}\text { Remains } \\
\text { GAP }\end{array}$ \\
\hline 177 & n-Pentane & $\begin{array}{l}\text { VOA } \\
\text { GC-MS }\end{array}$ & $\begin{array}{l}\text { EPA } 8260^{2} \\
\text { LA-523-118 }\end{array}$ & $\mathrm{N} / \mathrm{A}$ & & $X$ & & \\
\hline 178 & Tetrahydrofuran & $\begin{array}{l}\text { VOA } \\
\text { GC-MS }\end{array}$ & $\begin{array}{l}\text { EPA } 8260^{2} \\
\text { LA-523-118 }\end{array}$ & N/A & $\begin{array}{l}\text { proposed alternative EPA } \\
8261 \mathrm{VD} / \mathrm{GC} / \mathrm{MS}\end{array}$ & & $\mathrm{X}$ & \\
\hline 179 & 5-Methyl-2-hexanone & $\begin{array}{l}\text { VOA } \\
\text { GC-MS }\end{array}$ & $\begin{array}{l}\text { EPA } 8260 \\
\text { LA-523-118 }\end{array}$ & N/A & $\begin{array}{c}\text { proposed alternative EPA } \\
8315 \text { HPLC }\end{array}$ & & $\mathrm{X}$ & \\
\hline 180 & 2-Heptanone & $\begin{array}{l}\text { VOA } \\
\text { GC-MS }\end{array}$ & $\begin{array}{l}\text { EPA } 8260^{2} \\
\text { LA-523-118 }\end{array}$ & N/A & $\begin{array}{c}\text { proposed alternative EPA } \\
8315 \text { HPLC }\end{array}$ & & $\mathrm{X}$ & \\
\hline 181 & n-Hexane & $\begin{array}{l}\text { VOA } \\
\text { GC-MS }\end{array}$ & $\begin{array}{l}\text { EPA } 8260^{2} \\
\text { LA-523-118 }\end{array}$ & N/A & & $X$ & & \\
\hline 182 & Cyclohexane & $\begin{array}{l}\text { VOA } \\
\text { GC-MS }\end{array}$ & $\begin{array}{l}\text { EPA } 8260^{2} \\
\text { LA-523-118 }\end{array}$ & $\mathrm{N} / \mathrm{A}$ & & $X$ & & \\
\hline 183 & Cyclohexene & $\begin{array}{c}\text { VOA } \\
\text { GC-MS }\end{array}$ & $\begin{array}{l}\text { EPA } 8260^{2} \\
\text { LA-523-118 }\end{array}$ & N/A & & $X$ & & \\
\hline 184 & n-Octane & $\begin{array}{l}\text { VOA } \\
\text { GC-MS }\end{array}$ & $\begin{array}{l}\text { EPA } 8260^{2} \\
\text { LA-523-118 }\end{array}$ & N/A & & $\mathrm{X}$ & & \\
\hline 185 & n-Nonane & $\begin{array}{l}\text { VOA } \\
\text { GC-MS }\end{array}$ & $\begin{array}{l}\text { EPA } 8260^{2} \\
\text { LA-523-118 }\end{array}$ & N/A & & $X$ & & \\
\hline 186 & 4-Heptanone & $\begin{array}{l}\text { VOA } \\
\text { GC-MS }\end{array}$ & $\begin{array}{l}\text { EPA } 8260^{2} \\
\text { LA-523-118 }\end{array}$ & N/A & $\begin{array}{c}\text { proposed alternative EPA } \\
8315 \text { HPLC }\end{array}$ & & $\mathrm{x}$ & \\
\hline 187 & n-Propionaldehyde & $\begin{array}{l}\text { VOA } \\
\text { GC-MS }\end{array}$ & $\begin{array}{l}\text { EPA } 8260 \\
\text { LA-523-118 }\end{array}$ & N/A & $\begin{array}{c}\text { proposed alternative EPA } \\
8315 \text { HPLC }\end{array}$ & & $\mathrm{x}$ & \\
\hline
\end{tabular}




\begin{tabular}{|c|c|c|c|c|c|c|c|c|}
\hline \multirow{2}{*}{ Number } & \multirow{2}{*}{$\begin{array}{l}\text { WTP Processability } \\
\text { Parameter }\end{array}$} & \multirow{2}{*}{$\begin{array}{l}\text { WTP Proposed } \\
\text { Analytical } \\
\text { Methodology }\end{array}$} & \multirow{2}{*}{$\begin{array}{l}\text { WTP Suggested } \\
\text { Analytical } \\
\text { Methods } \\
\text { (Reference Only) }\end{array}$} & \multirow{2}{*}{$\begin{array}{l}\text { WTP Suggested } \\
\text { Sample } \\
\text { Preparations } \\
\text { (Reference Only) }\end{array}$} & \multirow{2}{*}{ SRNL Review Comments ${ }^{1}$} & \multicolumn{3}{|c|}{$\begin{array}{c}\text { SRNL Assessment of WTP } \\
\text { Proposed } \\
\text { Analytical Methodology } \\
\end{array}$} \\
\hline & & & & & & Concur & $\begin{array}{l}\text { Proposed } \\
\text { Alternative }\end{array}$ & $\begin{array}{l}\text { Remains } \\
\text { GAP }\end{array}$ \\
\hline 188 & $\begin{array}{l}\text { Acetic acid n-butyl } \\
\text { ester }\end{array}$ & $\begin{array}{c}\text { VOA } \\
\text { GC-MS }\end{array}$ & $\begin{array}{l}\text { EPA } 8260^{2} \\
\text { LA-523-118 }\end{array}$ & N/A & & $\mathrm{X}$ & & \\
\hline 189 & 1,4-Dioxane & $\begin{array}{l}\text { VOA } \\
\text { GC-MS }\end{array}$ & $\begin{array}{l}\text { EPA } 8260 \\
\text { LA-523-118 }\end{array}$ & N/A & & $\mathrm{X}$ & & \\
\hline 190 & $\begin{array}{l}\text { 2-Methyl-2- } \\
\text { propenenitrile }\end{array}$ & $\begin{array}{l}\text { VOA } \\
\text { GC-MS }\end{array}$ & $\begin{array}{l}\text { EPA } 8260^{2} \\
\text { LA-523-118 }\end{array}$ & N/A & & $\mathrm{X}$ & & \\
\hline 191 & $\begin{array}{c}1,1,2,2- \\
\text { Tetrachloroethene }\end{array}$ & $\begin{array}{l}\text { VOA } \\
\text { GC-MS }\end{array}$ & $\begin{array}{l}\text { EPA } 8260 \\
\text { LA-523-118 }\end{array}$ & N/A & & $\mathrm{X}$ & & \\
\hline 192 & $\begin{array}{l}\text { Acetic acid ethyl } \\
\text { ester }\end{array}$ & $\begin{array}{l}\text { VOA } \\
\text { GC-MS }\end{array}$ & $\begin{array}{l}\text { EPA } 8260^{2} \\
\text { LA-523-118 }\end{array}$ & N/A & & $\mathrm{X}$ & & \\
\hline 193 & n-Heptane & $\begin{array}{l}\text { VOA } \\
\text { GC-MS }\end{array}$ & $\begin{array}{l}\text { EPA } 8260^{2} \\
\text { LA-523-118 }\end{array}$ & N/A & & $\mathrm{X}$ & & \\
\hline 194 & Cyclopentane & $\begin{array}{l}\text { VOA } \\
\text { GC-MS }\end{array}$ & $\begin{array}{l}\text { EPA } 8260^{2} \\
\text { LA-523-118 }\end{array}$ & N/A & & $\mathrm{X}$ & & \\
\hline 195 & $\begin{array}{c}\text { 2-Butenaldehyde (2- } \\
\text { Butenal) }\end{array}$ & $\begin{array}{l}\text { VOA } \\
\text { GC-MS }\end{array}$ & $\begin{array}{l}\text { EPA } 8260^{2} \\
\text { LA-523-118 }\end{array}$ & $\mathrm{N} / \mathrm{A}$ & $\begin{array}{c}\text { proposed alternative EPA } \\
8315 \text { HPLC }\end{array}$ & & $\mathrm{X}$ & \\
\hline 196 & Carbon tetrachloride & $\begin{array}{l}\text { VOA } \\
\text { GC-MS }\end{array}$ & $\begin{array}{l}\text { EPA } 8260 \\
\text { LA-523-118 }\end{array}$ & N/A & & $\mathrm{X}$ & & \\
\hline 197 & 3-Methyl-2-butanone & $\begin{array}{l}\text { VOA } \\
\text { GC-MS }\end{array}$ & $\begin{array}{l}\text { EPA } 8260^{2} \\
\text { LA-523-118 }\end{array}$ & N/A & & $\mathrm{X}$ & & \\
\hline 198 & 2-Hexanone & $\begin{array}{l}\text { VOA } \\
\text { GC-MS }\end{array}$ & $\begin{array}{l}\text { EPA } 8260 \\
\text { LA-523-118 }\end{array}$ & N/A & & $\mathrm{X}$ & & \\
\hline
\end{tabular}




\begin{tabular}{|c|c|c|c|c|c|c|c|c|}
\hline \multirow{2}{*}{ Number } & \multirow{2}{*}{$\begin{array}{l}\text { WTP Processability } \\
\text { Parameter }\end{array}$} & \multirow{2}{*}{$\begin{array}{l}\text { WTP Proposed } \\
\text { Analytical } \\
\text { Methodology }\end{array}$} & \multirow{2}{*}{$\begin{array}{l}\text { WTP Suggested } \\
\text { Analytical } \\
\text { Methods } \\
\text { (Reference Only) }\end{array}$} & \multirow{2}{*}{$\begin{array}{l}\text { WTP Suggested } \\
\text { Sample } \\
\text { Preparations } \\
\text { (Reference Only) }\end{array}$} & \multirow{2}{*}{ SRNL Review Comments ${ }^{1}$} & \multicolumn{3}{|c|}{$\begin{array}{c}\text { SRNL Assessment of WTP } \\
\text { Proposed } \\
\text { Analytical Methodology } \\
\end{array}$} \\
\hline & & & & & & Concur & $\begin{array}{c}\text { Proposed } \\
\text { Alternative }\end{array}$ & $\begin{array}{l}\text { Remains } \\
\text { GAP }\end{array}$ \\
\hline 199 & Ethyl alcohol & $\begin{array}{l}\text { VOA } \\
\text { GC-MS }\end{array}$ & $\begin{array}{l}\text { EPA } 8260 \\
\text { LA-523-118 }\end{array}$ & N/A & & $\mathrm{X}$ & & \\
\hline 200 & Methyl alcohol & $\begin{array}{l}\text { VOA } \\
\text { GC-MS }\end{array}$ & $\begin{array}{c}\text { EPA } 8260 \\
\text { LA-523-118 }\end{array}$ & N/A & & $\mathrm{X}$ & & \\
\hline 201 & $\begin{array}{l}\text { 2-Propyl alcohol } \\
\text { (isopropanol) }\end{array}$ & $\begin{array}{l}\text { VOA } \\
\text { GC-MS }\end{array}$ & $\begin{array}{l}\text { EPA } 8260 \\
\text { LA-523-118 }\end{array}$ & N/A & & $\mathrm{X}$ & & \\
\hline 202 & $\begin{array}{l}\text { 2-Propanone } \\
\text { (Acetone) }\end{array}$ & $\begin{array}{l}\text { VOA } \\
\text { GC-MS }\end{array}$ & $\begin{array}{c}\text { EPA } 8260 \\
\text { LA-523-118 }\end{array}$ & N/A & & $\mathrm{X}$ & & \\
\hline 203 & Chloroform & $\begin{array}{c}\text { VOA } \\
\text { GC-MS }\end{array}$ & $\begin{array}{c}\text { EPA } 8260 \\
\text { LA-523-118 }\end{array}$ & N/A & & $\mathrm{X}$ & & \\
\hline 204 & Hexachloroethane & $\begin{array}{l}\text { VOA/SVOA } \\
\text { (VOA first, then } \\
\text { SVOA) } \\
\text { GC-MS }\end{array}$ & $\begin{array}{l}\text { EPA } 8260 / 8270 \\
\text { LA-523-118 } \\
\text { LA-523-135 }\end{array}$ & N/A & & $\mathrm{X}$ & & \\
\hline 205 & $\begin{array}{l}\text { n-Propyl alcohol (1- } \\
\text { propanol) }\end{array}$ & $\begin{array}{l}\text { VOA } \\
\text { GC-MS }\end{array}$ & $\begin{array}{l}\text { EPA } 8260 \\
\text { LA-523-118 }\end{array}$ & N/A & & $\mathrm{X}$ & & \\
\hline 206 & n-Butyl alcohol & $\begin{array}{l}\text { VOA } \\
\text { GC-MS }\end{array}$ & $\begin{array}{c}\text { EPA } 8260 \\
\text { LA-523-118 }\end{array}$ & N/A & & $\mathrm{X}$ & & \\
\hline 207 & Benzene & $\begin{array}{l}\text { VOA } \\
\text { GC-MS }\end{array}$ & $\begin{array}{c}\text { EPA } 8260 \\
\text { LA-523-118 }\end{array}$ & N/A & & $\mathrm{X}$ & & \\
\hline 208 & 1,1,1-Trichloroethane & $\begin{array}{c}\text { VOA } \\
\text { GC-MS }\end{array}$ & $\begin{array}{c}\text { EPA } 8260 \\
\text { LA-523-118 }\end{array}$ & N/A & & $\mathrm{X}$ & & \\
\hline 209 & Bromomethane & $\begin{array}{l}\text { VOA } \\
\text { GC-MS }\end{array}$ & $\begin{array}{c}\text { EPA } 8260 \\
\text { LA-523-118 }\end{array}$ & N/A & & $\mathrm{X}$ & & \\
\hline
\end{tabular}




\begin{tabular}{|c|c|c|c|c|c|c|c|c|}
\hline \multirow{2}{*}{ Number } & \multirow{2}{*}{$\begin{array}{l}\text { WTP Processability } \\
\text { Parameter }\end{array}$} & \multirow{2}{*}{$\begin{array}{c}\text { WTP Proposed } \\
\text { Analytical } \\
\text { Methodology }\end{array}$} & \multirow{2}{*}{$\begin{array}{l}\text { WTP Suggested } \\
\text { Analytical } \\
\text { Methods } \\
\text { (Reference Only) }\end{array}$} & \multirow{2}{*}{$\begin{array}{c}\text { WTP Suggested } \\
\text { Sample } \\
\text { Preparations } \\
\text { (Reference Only) }\end{array}$} & \multirow{2}{*}{ SRNL Review Comments ${ }^{1}$} & \multicolumn{3}{|c|}{$\begin{array}{c}\text { SRNL Assessment of WTP } \\
\text { Proposed } \\
\text { Analytical Methodology } \\
\end{array}$} \\
\hline & & & & & & Concur & $\begin{array}{c}\text { Proposed } \\
\text { Alternative }\end{array}$ & $\begin{array}{l}\text { Remains } \\
\text { GAP }\end{array}$ \\
\hline 210 & Chloromethane & $\begin{array}{l}\text { VOA } \\
\text { GC-MS }\end{array}$ & $\begin{array}{l}\text { EPA } 8260 \\
\text { LA-523-118 }\end{array}$ & N/A & & $\mathrm{x}$ & & \\
\hline 211 & Chloroethane & $\begin{array}{l}\text { VOA } \\
\text { GC-MS }\end{array}$ & $\begin{array}{l}\text { EPA } 8260 \\
\text { LA-523-118 }\end{array}$ & N/A & & $\mathrm{X}$ & & \\
\hline 212 & 1-Chloroethene & $\begin{array}{l}\text { VOA } \\
\text { GC-MS }\end{array}$ & $\begin{array}{l}\text { EPA } 8260 \\
\text { LA-523-118 }\end{array}$ & N/A & & $\mathrm{X}$ & & \\
\hline 213 & Acetonitrile & $\begin{array}{l}\text { VOA } \\
\text { GC-MS }\end{array}$ & $\begin{array}{l}\text { EPA } 8260 \\
\text { LA-523-118 }\end{array}$ & N/A & & $\mathrm{X}$ & & \\
\hline 214 & $\begin{array}{l}\text { Dichloromethane } \\
\text { (methylene chloride) }\end{array}$ & $\begin{array}{l}\text { VOA } \\
\text { GC-MS }\end{array}$ & $\begin{array}{l}\text { EPA } 8260 \\
\text { LA-523-118 }\end{array}$ & N/A & & $\mathrm{X}$ & & \\
\hline 215 & Carbon disulfide & $\begin{array}{l}\text { VOA } \\
\text { GC-MS }\end{array}$ & $\begin{array}{l}\text { EPA } 8260 \\
\text { LA-523-118 }\end{array}$ & N/A & & $\mathrm{x}$ & & \\
\hline 216 & Oxirane & $\begin{array}{l}\text { VOA } \\
\text { GC-MS }\end{array}$ & $\begin{array}{l}\text { EPA } 8260 \\
\text { LA-523-118 }\end{array}$ & N/A & & $\mathrm{X}$ & & \\
\hline 217 & 1,1-Dichloroethane & $\begin{array}{l}\text { VOA } \\
\text { GC-MS }\end{array}$ & $\begin{array}{l}\text { EPA } 8260 \\
\text { LA-523-118 }\end{array}$ & N/A & & $\mathrm{X}$ & & \\
\hline 218 & 1,1-Dichloroethene & $\begin{array}{l}\text { VOA } \\
\text { GC-MS }\end{array}$ & $\begin{array}{l}\text { EPA } 8260 \\
\text { LA-523-118 }\end{array}$ & N/A & & $\mathrm{X}$ & & \\
\hline 219 & $\begin{array}{l}\text { Dichlorofluorometha } \\
\text { ne }\end{array}$ & $\begin{array}{l}\text { VOA } \\
\text { GC-MS }\end{array}$ & $\begin{array}{l}\text { EPA } 8260 \\
\text { LA-523-118 }\end{array}$ & N/A & & $\mathrm{x}$ & & \\
\hline 220 & $\begin{array}{l}\text { Chlorodifluorometha } \\
\text { ne }\end{array}$ & $\begin{array}{l}\text { VOA } \\
\text { GC-MS }\end{array}$ & $\begin{array}{l}\text { EPA } 8260 \\
\text { LA-523-118 }\end{array}$ & N/A & $\begin{array}{l}\text { Gas so unlikely to be present } \\
\text { during analysis }\end{array}$ & $\mathrm{X}$ & & \\
\hline
\end{tabular}




\begin{tabular}{|c|c|c|c|c|c|c|c|c|}
\hline \multirow{2}{*}{ Number } & \multirow{2}{*}{$\begin{array}{l}\text { WTP Processability } \\
\text { Parameter }\end{array}$} & \multirow{2}{*}{$\begin{array}{l}\text { WTP Proposed } \\
\text { Analytical } \\
\text { Methodology }\end{array}$} & \multirow{2}{*}{$\begin{array}{l}\text { WTP Suggested } \\
\text { Analytical } \\
\text { Methods } \\
\text { (Reference Only) }\end{array}$} & \multirow{2}{*}{$\begin{array}{l}\text { WTP Suggested } \\
\text { Sample } \\
\text { Preparations } \\
\text { (Reference Only) }\end{array}$} & \multirow{2}{*}{ SRNL Review Comments ${ }^{1}$} & \multicolumn{3}{|c|}{$\begin{array}{c}\text { SRNL Assessment of WTP } \\
\text { Proposed } \\
\text { Analytical Methodology }\end{array}$} \\
\hline & & & & & & Concur & $\begin{array}{c}\text { Proposed } \\
\text { Alternative }\end{array}$ & $\begin{array}{l}\text { Remains } \\
\text { GAP }\end{array}$ \\
\hline 221 & 2-Methyl-2-propanol & $\begin{array}{c}\text { VOA } \\
\text { GC-MS }\end{array}$ & $\begin{array}{c}\text { EPA 8260 } \\
\text { LA-523-118 }\end{array}$ & N/A & & $\mathrm{X}$ & & \\
\hline 222 & $\begin{array}{l}\text { Trichlorofluorometha } \\
\text { ne }\end{array}$ & $\begin{array}{l}\text { VOA } \\
\text { GC-MS }\end{array}$ & $\begin{array}{c}\text { EPA } 8260 \\
\text { LA-523-118 }\end{array}$ & N/A & & $\mathrm{X}$ & & \\
\hline 223 & $\begin{array}{l}\text { Dichlorodifluorometh } \\
\text { ane }\end{array}$ & $\begin{array}{l}\text { VOA } \\
\text { GC-MS }\end{array}$ & $\begin{array}{l}\text { EPA } 8260 \\
\text { LA-523-118 }\end{array}$ & N/A & & $\mathrm{X}$ & & \\
\hline 224 & $\begin{array}{l}\text { 1,2,2-Trichloro-1,1,2- } \\
\text { trifluoroethane }\end{array}$ & $\begin{array}{l}\text { VOA } \\
\text { GC-MS }\end{array}$ & $\begin{array}{l}\text { EPA } 8260^{2} \\
\text { LA-523-118 }\end{array}$ & N/A & $\begin{array}{l}\text { low boiling, CFC-113, } \\
\text { Procurement of standards may } \\
\text { be difficult, not highly water } \\
\text { soluble }\end{array}$ & $\mathrm{X}$ & & \\
\hline 225 & $\begin{array}{l}\text { 1,2-Dichloro-1,1,2,2- } \\
\text { tetrafluoroethane }\end{array}$ & $\begin{array}{l}\text { VOA } \\
\text { GC-MS }\end{array}$ & $\begin{array}{l}\text { EPA } 8260^{2} \\
\text { LA-523-118 }\end{array}$ & N/A & $\begin{array}{l}\text { low boiling, CFC-113, } \\
\text { Procurement of standards may } \\
\text { be difficult, not highly water } \\
\text { soluble }\end{array}$ & $\mathrm{X}$ & & \\
\hline 226 & 1,2-Dichloropropane & $\begin{array}{l}\text { VOA } \\
\text { GC-MS }\end{array}$ & $\begin{array}{c}\text { EPA } 8260 \\
\text { LA-523-118 }\end{array}$ & N/A & & $\mathrm{X}$ & & \\
\hline 227 & $\begin{array}{l}\text { 1-Methylpropyl } \\
\text { alcohol (2-butanol) }\end{array}$ & $\begin{array}{l}\text { VOA } \\
\text { GC-MS }\end{array}$ & $\begin{array}{c}\text { EPA } 8260 \\
\text { LA-523-118 }\end{array}$ & N/A & & $\mathrm{X}$ & & \\
\hline 228 & 2-Butanone & $\begin{array}{l}\text { VOA } \\
\text { GC-MS }\end{array}$ & $\begin{array}{l}\text { EPA } 8260 \\
\text { LA-523-118 }\end{array}$ & N/A & & $\mathrm{X}$ & & \\
\hline 229 & 1,1,2-Trichloroethane & $\begin{array}{c}\text { VOA } \\
\text { GC-MS }\end{array}$ & $\begin{array}{c}\text { EPA } 8260 \\
\text { LA-523-118 }\end{array}$ & N/A & & $\mathrm{X}$ & & \\
\hline
\end{tabular}




\begin{tabular}{|c|c|c|c|c|c|c|c|c|}
\hline \multirow{2}{*}{ Number } & \multirow{2}{*}{$\begin{array}{l}\text { WTP Processability } \\
\text { Parameter }\end{array}$} & \multirow{2}{*}{$\begin{array}{l}\text { WTP Proposed } \\
\text { Analytical } \\
\text { Methodology }\end{array}$} & \multirow{2}{*}{$\begin{array}{l}\text { WTP Suggested } \\
\text { Analytical } \\
\text { Methods } \\
\text { (Reference Only) }\end{array}$} & \multirow{2}{*}{$\begin{array}{l}\text { WTP Suggested } \\
\text { Sample } \\
\text { Preparations } \\
\text { (Reference Only) }\end{array}$} & \multirow{2}{*}{ SRNL Review Comments ${ }^{1}$} & \multicolumn{3}{|c|}{$\begin{array}{c}\text { SRNL Assessment of WTP } \\
\text { Proposed } \\
\text { Analytical Methodology }\end{array}$} \\
\hline & & & & & & Concur & $\begin{array}{l}\text { Proposed } \\
\text { Alternative }\end{array}$ & $\begin{array}{l}\text { Remains } \\
\text { GAP }\end{array}$ \\
\hline 230 & $\begin{array}{c}1,1,2- \\
\text { Trichloroethylene }\end{array}$ & $\begin{array}{c}\text { VOA } \\
\text { GC-MS }\end{array}$ & $\begin{array}{l}\text { EPA } 8260 \\
\text { LA-523-118 }\end{array}$ & N/A & & $\mathrm{X}$ & & \\
\hline 231 & $\begin{array}{l}1,1,2,2- \\
\text { Tetrachloroethane }\end{array}$ & $\begin{array}{l}\text { VOA } \\
\text { GC-MS }\end{array}$ & $\begin{array}{l}\text { EPA } 8260 \\
\text { LA-523-118 }\end{array}$ & N/A & & $\mathrm{X}$ & & \\
\hline 232 & o-Xylene & $\begin{array}{l}\text { VOA } \\
\text { GC-MS }\end{array}$ & $\begin{array}{l}\text { EPA } 8260 \\
\text { LA-523-118 }\end{array}$ & N/A & & $\mathrm{X}$ & & \\
\hline 233 & 3-Pentanone & $\begin{array}{l}\text { VOA } \\
\text { GC-MS }\end{array}$ & $\begin{array}{l}\text { EPA } 8260 \\
\text { LA-523-118 }\end{array}$ & N/A & $\begin{array}{c}\text { proposed alternative EPA } \\
8315 \text { HPLC }\end{array}$ & & $X$ & \\
\hline 234 & Arochlor-1260 & $\begin{array}{c}\text { PCB } \\
\text { GC-ECD } \\
\text { SVOA } \\
\text { GC-MS }\end{array}$ & $\begin{array}{c}\text { EPA } 8082 \\
\text { EPA } 8270 \\
\text { LA-523-140 } \\
\text { LA-523-135 } \\
\text { Screening analysis } \\
\text { per LA-523-146 }\end{array}$ & $\begin{array}{l}\text { LA-523-115 } \\
\text { LA-523-138 } \\
\text { LA-523-141 } \\
\text { LA-523-144 } \\
\text { LA-523-145 }\end{array}$ & & $\mathrm{X}$ & & \\
\hline 235 & Arochlor-1254 & $\begin{array}{c}\text { PCB } \\
\text { GC-ECD } \\
\text { SVOA } \\
\text { GC-MS }\end{array}$ & $\begin{array}{c}\text { EPA } 8082 \\
\text { EPA } 8270 \\
\text { LA-523-140 } \\
\text { LA-523-135 } \\
\text { Screening analysis } \\
\text { per LA-523-146 }\end{array}$ & $\begin{array}{l}\text { LA-523-115 } \\
\text { LA-523-138 } \\
\text { LA-523-141 } \\
\text { LA-523-144 } \\
\text { LA-523-145 }\end{array}$ & & $\mathrm{X}$ & & \\
\hline 236 & Arochlor-1221 & $\begin{array}{c}\text { PCB } \\
\text { GC-ECD } \\
\text { SVOA } \\
\text { GC-MS }\end{array}$ & $\begin{array}{c}\text { EPA } 8082 \\
\text { EPA } 8270 \\
\text { LA-523-140 } \\
\text { LA-523-135 } \\
\text { Screening analysis } \\
\text { per LA-523-146 }\end{array}$ & $\begin{array}{l}\text { LA-523-115 } \\
\text { LA-523-138 } \\
\text { LA-523-141 } \\
\text { LA-523-144 } \\
\text { LA-523-145 }\end{array}$ & & $\mathrm{X}$ & & \\
\hline
\end{tabular}




\begin{tabular}{|c|c|c|c|c|c|c|c|c|}
\hline \multirow{2}{*}{ Number } & \multirow{2}{*}{$\begin{array}{l}\text { WTP Processability } \\
\text { Parameter }\end{array}$} & \multirow{2}{*}{$\begin{array}{l}\text { WTP Proposed } \\
\text { Analytical } \\
\text { Methodology }\end{array}$} & \multirow{2}{*}{$\begin{array}{l}\text { WTP Suggested } \\
\text { Analytical } \\
\text { Methods } \\
\text { (Reference Only) }\end{array}$} & \multirow{2}{*}{$\begin{array}{c}\text { WTP Suggested } \\
\text { Sample } \\
\text { Preparations } \\
\text { (Reference Only) }\end{array}$} & \multirow{2}{*}{ SRNL Review Comments ${ }^{1}$} & \multicolumn{3}{|c|}{$\begin{array}{c}\text { SRNL Assessment of WTP } \\
\text { Proposed } \\
\text { Analytical Methodology }\end{array}$} \\
\hline & & & & & & Concur & $\begin{array}{c}\text { Proposed } \\
\text { Alternative }\end{array}$ & $\begin{array}{c}\text { Remains } \\
\text { GAP }\end{array}$ \\
\hline 237 & Arochlor-1232 & $\begin{array}{l}\text { PCB } \\
\text { GC-ECD } \\
\text { SVOA } \\
\text { GC-MS }\end{array}$ & $\begin{array}{c}\text { EPA } 8082 \\
\text { EPA } 8270 \\
\text { LA-523-140 } \\
\text { LA-523-135 } \\
\text { Screening analysis } \\
\text { per LA-523-146 }\end{array}$ & $\begin{array}{l}\text { LA-523-115 } \\
\text { LA-523-138 } \\
\text { LA-523-141 } \\
\text { LA-523-144 } \\
\text { LA-523-145 }\end{array}$ & & $X$ & & \\
\hline 238 & Arochlor-1248 & $\begin{array}{l}\text { PCB } \\
\text { GC-ECD } \\
\text { SVOA } \\
\text { GC-MS }\end{array}$ & $\begin{array}{c}\text { EPA } 8082 \\
\text { EPA } 8270 \\
\text { LA-523-140 } \\
\text { LA-523-135 } \\
\text { Screening analysis } \\
\text { per LA-523-146 }\end{array}$ & $\begin{array}{l}\text { LA-523-115 } \\
\text { LA-523-138 } \\
\text { LA-523-141 } \\
\text { LA-523-144 } \\
\text { LA-523-145 }\end{array}$ & & $\mathrm{X}$ & & \\
\hline 239 & Arochlor-1016 & $\begin{array}{l}\text { PCB } \\
\text { GC-ECD } \\
\text { SVOA } \\
\text { GC-MS }\end{array}$ & $\begin{array}{c}\text { EPA } 8082 \\
\text { EPA } 8270 \\
\text { LA-523-140 } \\
\text { LA-523-135 } \\
\text { Screening analysis } \\
\text { per LA-523-146 }\end{array}$ & $\begin{array}{l}\text { LA-523-115 } \\
\text { LA-523-138 } \\
\text { LA-523-141 } \\
\text { LA-523-144 } \\
\text { LA-523-145 }\end{array}$ & & $X$ & & \\
\hline 240 & Arochlor-1242 & $\begin{array}{l}\text { PCB } \\
\text { GC-ECD } \\
\text { SVOA } \\
\text { GC-MS }\end{array}$ & $\begin{array}{c}\text { EPA 8082 } \\
\text { EPA 8270 } \\
\text { LA-523-140 } \\
\text { LA-523-135 } \\
\text { Screening analysis } \\
\text { per LA-523-146 }\end{array}$ & $\begin{array}{l}\text { LA-523-115 } \\
\text { LA-523-138 } \\
\text { LA-523-141 } \\
\text { LA-523-144 } \\
\text { LA-523-145 }\end{array}$ & & $X$ & & \\
\hline 241 & Hexachlorobenzene & $\begin{array}{l}\text { Pesticide } \\
\text { SVOA } \\
\text { GC-MS } \\
\text { GC-ECD }\end{array}$ & $\begin{array}{c}\text { EPA } 8082 \\
\text { EPA 8270 } \\
\text { EPA 8081 } \\
\text { LA-523-140 } \\
\text { LA-523-135 } \\
\text { LA-523-162 }\end{array}$ & $\begin{array}{l}\text { LA-523-115 } \\
\text { LA-523-138 } \\
\text { LA-523-141 } \\
\text { LA-523-144 } \\
\text { LA-523-145 }\end{array}$ & & $\mathrm{X}$ & & \\
\hline
\end{tabular}




\begin{tabular}{|c|c|c|c|c|c|c|c|c|}
\hline \multirow{2}{*}{ Number } & \multirow{2}{*}{$\begin{array}{l}\text { WTP Processability } \\
\text { Parameter }\end{array}$} & \multirow{2}{*}{$\begin{array}{l}\text { WTP Proposed } \\
\text { Analytical } \\
\text { Methodology }\end{array}$} & \multirow{2}{*}{$\begin{array}{l}\text { WTP Suggested } \\
\text { Analytical } \\
\text { Methods } \\
\text { (Reference Only) }\end{array}$} & \multirow{2}{*}{$\begin{array}{c}\text { WTP Suggested } \\
\text { Sample } \\
\text { Preparations } \\
\text { (Reference Only) }\end{array}$} & \multirow{2}{*}{ SRNL Review Comments ${ }^{1}$} & \multicolumn{3}{|c|}{$\begin{array}{c}\text { SRNL Assessment of WTP } \\
\text { Proposed } \\
\text { Analytical Methodology } \\
\end{array}$} \\
\hline & & & & & & Concur & $\begin{array}{c}\text { Proposed } \\
\text { Alternative }\end{array}$ & $\begin{array}{c}\text { Remains } \\
\text { GAP }\end{array}$ \\
\hline 242 & $\begin{array}{l}\text { Octachloronaphthale } \\
\text { ne }\end{array}$ & $\begin{array}{l}\text { Pesticide } \\
\text { SVOA } \\
\text { GC-MS } \\
\text { GC-ECD }\end{array}$ & $\begin{array}{l}\text { EPA } 8270 \\
\text { EPA } 8081 \\
\text { LA-523-135 } \\
\text { LA-523-162 }\end{array}$ & $\begin{array}{l}\text { LA-523-115 } \\
\text { LA-523-138 } \\
\text { LA-523-141 } \\
\text { LA-523-144 } \\
\text { LA-523-145 }\end{array}$ & $\begin{array}{l}\text { method is for Liq/Liq } \\
\text { extraction but this is a solid, } \\
\text { Cambridge isotopes sells } \\
\text { standard }\end{array}$ & $X$ & & \\
\hline 243 & $\begin{array}{l}\text { Pentachloronaphthale } \\
\text { ne }\end{array}$ & $\begin{array}{l}\text { Pesticide } \\
\text { SVOA } \\
\text { GC-MS } \\
\text { GC-ECD }\end{array}$ & $\begin{array}{l}\text { EPA } 8270 \\
\text { EPA } 8081 \\
\text { LA-523-135 } \\
\text { LA-523-162 }\end{array}$ & $\begin{array}{l}\text { LA-523-115 } \\
\text { LA-523-138 } \\
\text { LA-523-141 } \\
\text { LA-523-144 } \\
\text { LA-523-145 }\end{array}$ & $\begin{array}{l}\text { method is for Liq/Liq } \\
\text { extraction but this is a solid, } \\
\text { Cambridge isotopes sells } \\
\text { standard }\end{array}$ & $X$ & & \\
\hline 244 & $\begin{array}{l}\text { Hexachloronaphthale } \\
\text { ne }\end{array}$ & $\begin{array}{l}\text { Pesticide } \\
\text { SVOA } \\
\text { GC-MS }^{3} \\
\text { GC-ECD }\end{array}$ & $\begin{array}{l}\text { EPA } 8270 \\
\text { EPA } 8081 \\
\text { LA-523-135 } \\
\text { LA-523-162 }\end{array}$ & $\begin{array}{l}\text { LA-523-115 } \\
\text { LA-523-138 } \\
\text { LA-523-141 } \\
\text { LA-523-144 } \\
\text { LA-523-145 }\end{array}$ & $\begin{array}{c}\text { method is for } \mathrm{Liq} / \mathrm{Liq} \\
\text { extraction but this is a solid, } \\
\text { Cambridge isotopes sells } \\
\text { standard }\end{array}$ & $\mathrm{X}$ & & \\
\hline 245 & $\begin{array}{l}\text { Tetrachloronaphthale } \\
\text { ne }\end{array}$ & $\begin{array}{l}\text { Pesticide } \\
\text { SVOA } \\
\text { GC-MS } \\
\text { GC-ECD }\end{array}$ & $\begin{array}{l}\text { EPA } 8270 \\
\text { EPA } 8081 \\
\text { LA-523-135 } \\
\text { LA-523-162 }\end{array}$ & $\begin{array}{l}\text { LA-523-115 } \\
\text { LA-523-138 } \\
\text { LA-523-141 } \\
\text { LA-523-144 } \\
\text { LA-523-145 }\end{array}$ & $\begin{array}{c}\text { method is for } \mathrm{Liq} / \mathrm{Liq} \\
\text { extraction but this is a solid, } \\
\text { Cambridge isotopes sells } \\
\text { standard }\end{array}$ & $X$ & & \\
\hline 246 & Aldrin & $\begin{array}{l}\text { Pesticide } \\
\text { SVOA } \\
\text { GC-MS } \\
\text { GC-ECD }\end{array}$ & $\begin{array}{l}\text { EPA } 8270 \\
\text { EPA } 8081 \\
\text { LA-523-135 } \\
\text { LA-523-162 }\end{array}$ & $\begin{array}{l}\text { LA-523-115 } \\
\text { LA-523-138 } \\
\text { LA-523-141 } \\
\text { LA-523-144 } \\
\text { LA-523-145 }\end{array}$ & also EPA 8085 GC/AED & $\mathrm{X}$ & & \\
\hline 247 & alpha-BHC & $\begin{array}{l}\text { Pesticide } \\
\text { SVOA } \\
\text { GC-MS } \\
\text { GC-ECD }\end{array}$ & $\begin{array}{l}\text { EPA } 8270 \\
\text { EPA } 8081 \\
\text { LA-523-135 } \\
\text { LA-523-162 }\end{array}$ & $\begin{array}{l}\text { LA-523-115 } \\
\text { LA-523-138 } \\
\text { LA-523-141 } \\
\text { LA-523-144 } \\
\text { LA-523-145 }\end{array}$ & also EPA 8085 GC/AED & $\mathrm{X}$ & & \\
\hline
\end{tabular}




\begin{tabular}{|c|c|c|c|c|c|c|c|c|}
\hline \multirow{2}{*}{ Number } & \multirow{2}{*}{$\begin{array}{l}\text { WTP Processability } \\
\text { Parameter }\end{array}$} & \multirow{2}{*}{$\begin{array}{l}\text { WTP Proposed } \\
\text { Analytical } \\
\text { Methodology }\end{array}$} & \multirow{2}{*}{$\begin{array}{l}\text { WTP Suggested } \\
\text { Analytical } \\
\text { Methods } \\
\text { (Reference Only) }\end{array}$} & \multirow{2}{*}{$\begin{array}{c}\text { WTP Suggested } \\
\text { Sample } \\
\text { Preparations } \\
\text { (Reference Only) }\end{array}$} & \multirow{2}{*}{ SRNL Review Comments ${ }^{1}$} & \multicolumn{3}{|c|}{$\begin{array}{c}\text { SRNL Assessment of WTP } \\
\text { Proposed } \\
\text { Analytical Methodology }\end{array}$} \\
\hline & & & & & & Concur & $\begin{array}{c}\text { Proposed } \\
\text { Alternative }\end{array}$ & $\begin{array}{c}\text { Remains } \\
\text { GAP }\end{array}$ \\
\hline 248 & beta-BHC & $\begin{array}{l}\text { Pesticide } \\
\text { SVOA } \\
\text { GC-MS } \\
\text { GC-ECD }\end{array}$ & $\begin{array}{l}\text { EPA } 8270 \\
\text { EPA } 8081 \\
\text { LA-523-135 } \\
\text { LA-523-162 }\end{array}$ & $\begin{array}{l}\text { LA-523-115 } \\
\text { LA-523-138 } \\
\text { LA-523-141 } \\
\text { LA-523-144 } \\
\text { LA-523-145 }\end{array}$ & also EPA 8085 GC/AED & $X$ & & \\
\hline 249 & Isodrin & $\begin{array}{l}\text { Pesticide } \\
\text { SVOA } \\
\text { GC-MS } \\
\text { GC-ECD }\end{array}$ & $\begin{array}{l}\text { EPA } 8270 \\
\text { EPA } 8081 \\
\text { LA-523-135 } \\
\text { LA-523-162 }\end{array}$ & $\begin{array}{l}\text { LA-523-115 } \\
\text { LA-523-138 } \\
\text { LA-523-141 } \\
\text { LA-523-144 } \\
\text { LA-523-145 }\end{array}$ & & $\mathrm{X}$ & & \\
\hline 250 & $\begin{array}{l}\text { Gamma-BHC } \\
\text { (Lindane) }\end{array}$ & $\begin{array}{l}\text { Pesticide } \\
\text { SVOA } \\
\text { GC-MS } \\
\text { GC-ECD }\end{array}$ & $\begin{array}{l}\text { EPA } 8270 \\
\text { EPA } 8081 \\
\text { LA-523-135 } \\
\text { LA-523-162 }\end{array}$ & $\begin{array}{l}\text { LA-523-115 } \\
\text { LA-523-138 } \\
\text { LA-523-141 } \\
\text { LA-523-144 } \\
\text { LA-523-145 }\end{array}$ & also EPA 8085 GC/AED & $X$ & & \\
\hline 251 & Dieldrin & $\begin{array}{l}\text { Pesticide } \\
\text { SVOA } \\
\text { GC-MS } \\
\text { GC-ECD }\end{array}$ & $\begin{array}{l}\text { EPA } 8270 \\
\text { EPA } 8081 \\
\text { LA-523-135 } \\
\text { LA-523-162 }\end{array}$ & $\begin{array}{l}\text { LA-523-115 } \\
\text { LA-523-138 } \\
\text { LA-523-141 } \\
\text { LA-523-144 } \\
\text { LA-523-145 }\end{array}$ & also EPA 8085 GC/AED & $X$ & & \\
\hline 252 & Endrin & $\begin{array}{l}\text { Pesticide } \\
\text { SVOA } \\
\text { GC-MS } \\
\text { GC-ECD }\end{array}$ & $\begin{array}{l}\text { EPA } 8270 \\
\text { EPA } 8081 \\
\text { LA-523-135 } \\
\text { LA-523-162 }\end{array}$ & $\begin{array}{l}\text { LA-523-115 } \\
\text { LA-523-138 } \\
\text { LA-523-141 } \\
\text { LA-523-144 } \\
\text { LA-523-145 }\end{array}$ & also EPA 8085 GC/AED & $\mathrm{X}$ & & \\
\hline 253 & Heptachlor & $\begin{array}{l}\text { Pesticide } \\
\text { SVOA } \\
\text { GC-MS } \\
\text { GC-ECD }\end{array}$ & $\begin{array}{l}\text { EPA } 8270 \\
\text { EPA } 8081 \\
\text { LA-523-135 } \\
\text { LA-523-162 }\end{array}$ & $\begin{array}{l}\text { LA-523-115 } \\
\text { LA-523-138 } \\
\text { LA-523-141 } \\
\text { LA-523-144 } \\
\text { LA-523-145 }\end{array}$ & also EPA 8085 GC/AED & $X$ & & \\
\hline
\end{tabular}




\begin{tabular}{|c|c|c|c|c|c|c|c|c|}
\hline \multirow{2}{*}{ Number } & \multirow{2}{*}{$\begin{array}{l}\text { WTP Processability } \\
\text { Parameter }\end{array}$} & \multirow{2}{*}{$\begin{array}{c}\text { WTP Proposed } \\
\text { Analytical } \\
\text { Methodology }\end{array}$} & \multirow{2}{*}{$\begin{array}{l}\text { WTP Suggested } \\
\text { Analytical } \\
\text { Methods } \\
\text { (Reference Only) }\end{array}$} & \multirow{2}{*}{$\begin{array}{l}\text { WTP Suggested } \\
\text { Sample } \\
\text { Preparations } \\
\text { (Reference Only) }\end{array}$} & \multirow{2}{*}{ SRNL Review Comments ${ }^{1}$} & \multicolumn{3}{|c|}{$\begin{array}{c}\text { SRNL Assessment of WTP } \\
\text { Proposed } \\
\text { Analytical Methodology } \\
\end{array}$} \\
\hline & & & & & & Concur & $\begin{array}{c}\text { Proposed } \\
\text { Alternative }\end{array}$ & $\begin{array}{c}\text { Remains } \\
\text { GAP }\end{array}$ \\
\hline 254 & Toxaphene & $\begin{array}{c}\text { Pesticide } \\
\text { SVOA } \\
\text { GC-MS } \\
\text { GC-ECD }\end{array}$ & $\begin{array}{l}\text { EPA } 8270 \\
\text { EPA } 8081 \\
\text { LA-523-135 } \\
\text { LA-523-162 }\end{array}$ & $\begin{array}{l}\text { LA-523-115 } \\
\text { LA-523-138 } \\
\text { LA-523-141 } \\
\text { LA-523-144 } \\
\text { LA-523-145 } \\
\end{array}$ & & $\mathrm{X}$ & & \\
\hline 255 & $\begin{array}{c}\text { Oxalic acid } \\
\text { (Same as Oxalate) } \\
\text { (See Item \#84.2) }\end{array}$ & $\begin{array}{l}\text { Small Organic } \\
\text { Acid } \\
\text { (reported as } \\
\text { anion) } \\
\text { IC }\end{array}$ & $\begin{array}{c}\text { EPA } 9056 \\
\text { LA-533-115 }\end{array}$ & N/A & oxalate & $\mathrm{X}$ & & \\
\hline 256 & Formic acid & $\begin{array}{l}\text { Small Organic } \\
\text { Acid } \\
\text { (reported as } \\
\text { anion) } \\
\text { IC } \\
\end{array}$ & $\begin{array}{c}\text { EPA 9056 } \\
\text { LA-533-115 }\end{array}$ & N/A & formate & $\mathrm{X}$ & & \\
\hline 257 & Acetic acid & $\begin{array}{l}\text { Small Organic } \\
\text { Acid } \\
\text { (reported as } \\
\text { anion) } \\
\text { IC }\end{array}$ & $\begin{array}{c}\text { EPA } 9056 \\
\text { LA-533-115 }\end{array}$ & N/A & acetate & $\mathrm{X}$ & & \\
\hline 258 & $\begin{array}{l}\text { 2-Propenoic acid } \\
\text { (Acrylic Acid) }\end{array}$ & $\begin{array}{l}\text { Small Organic } \\
\text { Acid } \\
\text { (reported as } \\
\text { anion) } \\
\text { IC }\end{array}$ & EPA $9056^{2}$ & N/A & propionate & $\mathrm{X}$ & & \\
\hline
\end{tabular}

${ }^{1}$ Note:

CAS: Chemical Abstracts Service

CFC: chlorofluorocarbon

DQO: data quality objective

EPA: US Environmental Protection Agency (SW-846 reference method)

GC/AED: gas chromatography / atomic emission detector

GC-ECD: gas chromatography - electron capture detector

GC-MS: gas chromatography - mass spectrometry 
HPLC: high performance liquid chromatography

PCB: polychlorinated biphenyl

SVOA: semivolatile organic analysis

VD: vacuum distillation

VOA: volatile organic analysis

N/A: not applicable

SRNL: Savannah River National Laboratory

WAC: waste acceptance criteria

WTP: Hanford Tank Waste Treatment and Immobilization Plant

${ }^{2}$ Note: Although the constituent is not listed in the EPA recommended method, WTP demonstrated method applicability using performance based measurement approach for tank waste matrices. The demonstration is documented in sections 8 and 9 of the RDQO Optimization report (24590-WTP-RPT-MGT-04-001, Rev 0).

${ }^{3}$ Note: Procurement of standards for calibration/quantitation may be difficult. 


\section{Distribution:}

\section{SRNL}

A. P. Fellinger, 773-41A

K.M. Fox, 999-W

S. D. Fink, 773-A

B. J. Giddings, 786-5A

J. C. Griffin, 773-A

C. C. Herman, 999-W

S. L. Marra, 773-A

F. M. Pennebaker, 773-42A

W. R. Wilmarth, 773-A

D.J. Adamson, 999-W

C. J. Bannochie, 773-42A

A.D. Cozzi, 999-W

R.E. Eibling, 999-W

M.S. Hay, 773-42A

E.K. Hansen, 999-W

D.T. Herman, 735-11A

C.J. Martino, 773-42A

C.A. Nash, 773-42A

D. K. Peeler, 999-W

M.R. Poirier, 773-42A

S.H. Reboul, 773-A

M.E. Stone, 999-W

K.M. Taylor-Pashow, 773-A

T.L. White, 773-A
WTP
A. Arakali, MS 12-2B
P. Benson, MS 12-2B
T. Halverson, MS 12-2B
M. Hamlet, MS 10-E
D. Herting, MS 17-A
J. Johnston, MS 10-E
T. Lane, MS 10-E
J. Markillie, MS 12-2B
G. Matis, MS 12-2B
M. Miller, MS 12-2B 